
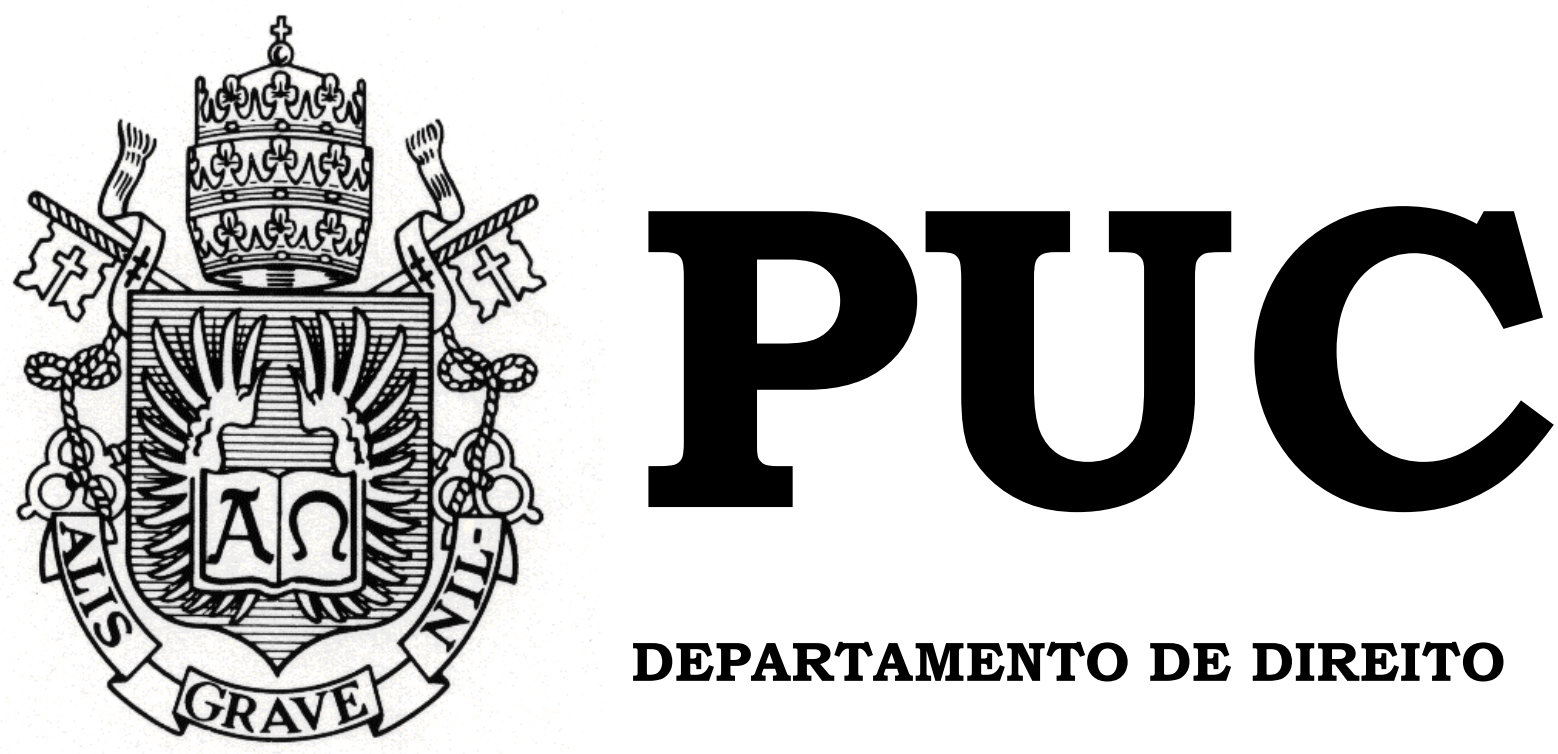

DEPARTAMENTO DE DIREITO

\title{
O CAMINHO DA ADOÇÃO NO DIREITO BRASILEIRO
}

Por

ÉRIKA FELDMAN

ORIENTADORA: Inês Alegria Rocumback 2019.2

PONTIFÍCIA UNIVERSIDADE CATÓLICA DO RIO DE JANEIRO RUA MARQUÊS DE SÃO VICENTE, 225 - CEP 22451-900 RIO DE JANEIRO - BRASIL 


\title{
O CAMINHO DA ADOÇÃO NO DIREITO BRASILEIRO
}

\author{
por
}

\section{ÉRIKA FELDMAN}

\begin{abstract}
Monografia apresentada ao
Departamento de Direito da

Pontificia Universidade Católica do

Rio de Janeiro (PUC-Rio) para a

obtenção do Título de Bacharel em

Direito.
\end{abstract}

Orientador: Inês Alegria Rocumback 


\section{AGRADECIMENTOS}

Com a aproximação do encerramento de um ciclo tão intenso e feliz, que me fez amadurecer como mulher e profissional, eu não poderia deixar de agradecer às principais pessoas que estiveram ao meu lado.

Tenho o prazer de dizer que fui presenteada com anjos ao longo da minha vida e eles me fizeram entender que o caminho é longo, mas nunca será solitário.

Primeiramente, gostaria de agradecer aos meus pais, Céu e Léo Feldman, por não medirem esforços para me amar, por terem sido presentes em cada passo da minha caminhada e por me darem a oportunidade de crescer num lar cercado de respeito e segurança. Obrigada por me ensinarem o verdadeiro significado de diálogo, vocês sempre serão o meu maior exemplo de integridade e companheirismo.

À Karen Feldman, companheira de 23 anos de caminhada, que antes de irmã, foi escolhida como amiga. Obrigada por todo o apoio e por me mostrar que é possível ser uma profissional tecnicamente exemplar, sem esquecer-se do coração.

À minha segunda mãe, Vera Lúcia Ribeiro Ferreira, que me mostrou desde pequena que o afeto é mais importante do que qualquer laço sanguíneo.

Ao meu namorado, Caio Nogaroli, que me trouxe ensinamentos profundos de forma suave, agradeço pelo companheirismo, por não me deixar esquecer os meus princípios e por me trazer de volta a sensação de receber um abraço de avôs nos almoços de domingo.

À Anabella, Isabella, Júlia, Rafaela, Raissa, Vitória e Victória, por terem me acompanhado nesses cinco anos de PUC-Rio, por me questionarem sobre o meu papel na sociedade e me fazerem uma pessoa melhor a cada encontro. 
À minha parceira Naomi, pela sintonia inexplicável e por ter sido porto-seguro diante de vitórias e derrotas nessa caminhada como mulher, filha, judia, amiga, acadêmica do curso de direito e nova profissional.

Às amigas Carolina, Eduarda, Gabriela, Giovanna, Tatiana, Juliana e Vivian, pelo apoio, pelos conselhos, e por me mostrarem, mais uma vez, que o poder feminino é incomparável e que podemos chegar aonde quisermos desde que estejamos juntas.

À minha mentora, Inês Alegria Rocumback, por ter me ensinado o verdadeiro significado de ser uma líder, por ter confiado no meu potencial e por ter dividido comigo o seu amor ao Direito de Família no Núcleo de Práticas Jurídicas da PUC-Rio.

À Natalia Winter, amiga que as Práticas Colaborativas trouxeram para o meu universo, por ter acreditado no meu potencial quando eu estava prestes a perder as minhas esperanças.

Ao Habonim Dror, movimento juvenil judaico do qual participei por 15 anos, agradeço por ter me introduzido ao mundo da educação e me dado a oportunidade de descobrir que a minha vocação é cuidar e aprender com as crianças.

À Carla Amigo, Cíntia Damasceno, Felipe Camargo, Luciana Pedras, Paula Abib e Raphael Mançur, como representantes daqueles com quem cruzei nos diferentes estágios acadêmicos, agradeço por compartilharem comigo a paixão pelo Direito, por serem exemplos de profissionais éticos e me ajudarem a crescer. 


\section{RESUMO}

FELDMAN, Érika. O caminho da adoção no Direito Brasileiro. Rio de Janeiro: 2019: 113 p. Monografia de final de curso. Departamento de Direito da Pontifícia Universidade Católica do Rio de Janeiro - PUC-Rio.

O presente trabalho tem como objetivo discorrer acerca da adoção no Brasil, por meio de uma análise história do desenvolvimento do direito da criança e do adolescente e, principalmente, dessa influência na evolução das normativas brasileiras. Busca-se entender os fundamentos que regulam o processo de adoção nos moldes atuais e, consequentemente, o caráter excepcional estabelecido a essa medida. Destaca-se também o lugar em que são inseridas as famílias que se candidatam à adoção, por meio da explicação das inúmeras etapas por trás desse procedimento: a entrega, o acolhimento, o processo de destituição do poder familiar, a habilitação, o cadastramento e a diferença de tratamento relativa ao processo de adoção nacional em relação ao processo internacional. Por fim, são destacadas as alterações normativas e inovações acerca do tema, oriundas do atual paradigma do Direito das Famílias, o vínculo do afeto.

Palavras-Chave: Adoção; Direito da criança; Filhos; Tipos de adoção; Acolhimento; Perda do poder familiar; Cadastramento; Habilitação; Adoção internacional; Estatuto da Criança e do Adolescente; Vínculo afetivo. 


\section{SUMÁRIO}

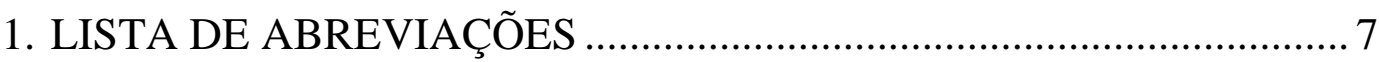

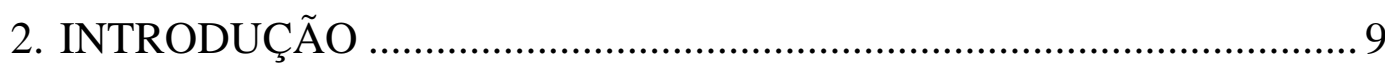

3. A EVOLUÇÃO DO DIREITO DA CRIANÇA E DO ADOLESCENTE 13

4. A EVOLUÇÃO DAS NORMATIVAS BRASILEIRAS NO DIREITO DA CRIANÇA E DO ADOLESCENTE ................................................... 18

5. OS FILHOS DAS DIFERENTES DÉCADAS …………………...........2 22

6. DA PREVALÊNCIA DA FAMÍLIA NATURAL À EXCEPCIONALIDADE DA ADOÇÃO ................................................. 33

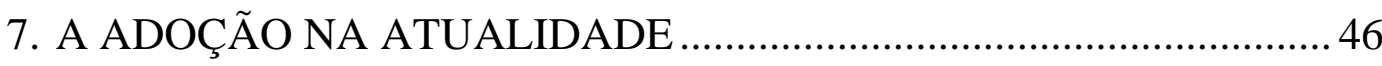

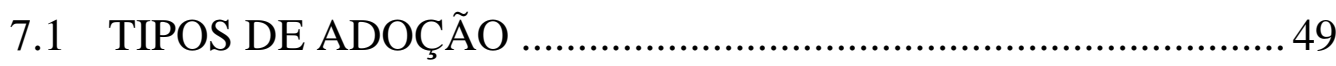

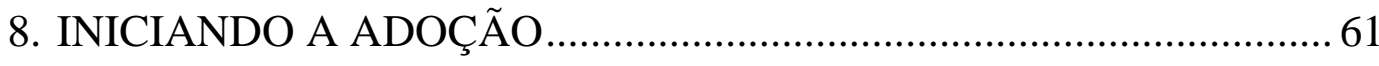

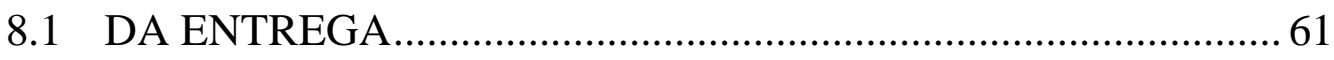

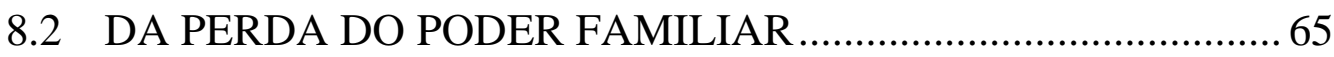

9. DA HABILITAÇÃO DOS PAIS DE AFETO........................................... 72

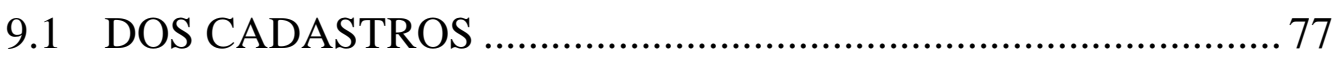

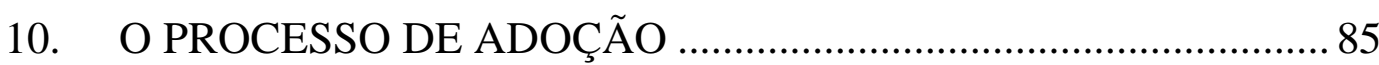

11. NUÂNCES DAS ADOÇÕES INTERNACIONAIS ........................ 91

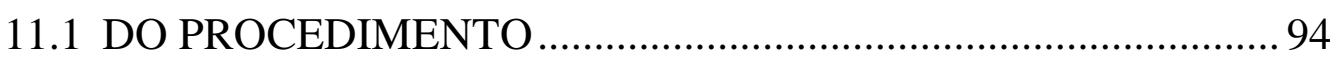

12. NOVOS OLHARES E NOVAS PRÁTICAS …................................. 99

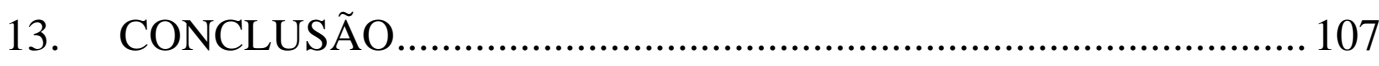

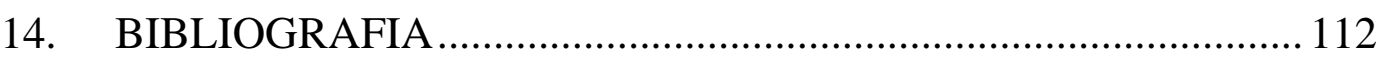




\section{LISTA DE ABREVIAÇÕES}

ECA - Estatuto da Criança e do Adolescente

STJ - Superior Tribunal de Justiça

STF - Supremo Tribunal Federal

ANGAAD - Associação Nacional de Grupos de Apoio à Adoção

VIJI - Vara da Infância, da Juventude e do Idoso

TJ - Tribunal de Justiça

CNA - Cadastro Nacional de Adoção

SNA - Sistema Nacional de Adoção e Acolhimento

CNJ - Conselho Nacional de Justiça 
"Vocês dizem:

- Cansa-nos ter de privar com crianças.

Têm razão.

Vocês dizem ainda:

- Cansa-nos, porque precisamos descer ao seu nível de compreensão.

Descer, rebaixar-se, inclinar-se, ficar curvado.

Estão equivocados.

- Não é isto o que nos cansa, e sim, o fato de termos de elevar-nos até alcançar o nível dos sentimentos das crianças.

Elevar-nos, subir, ficar na ponta dos pés, estender a mão.

Para não machucá-las. ”

Janusz Korczak

"É dificil em tempos como estes: ideais, sonhos e esperanças permanecerem dentro de nós, sendo esmagados pela dura realidade. É um milagre eu não ter abandonado todos os meus ideais, eles parecem tão absurdos e impraticáveis. No entanto, eu me apego a eles, porque eu ainda acredito, apesar de tudo, que as pessoas são realmente boas de coração”.

Anne Frank 


\section{INTRODUÇÃO}

A criança e o adolescente nem sempre foram compreendidos como sujeitos de direito, sendo a sua proteção resultado de um longo processo jurídico social - tanto no âmbito nacional quanto no internacional -, abrangido internamente por três etapas definidas pela doutrina como a Doutrina Penal do Menor, a Doutrina da Situação Irregular e, por fim, a Doutrina da Proteção Integral, baseada na Convenção dos Direitos da Criança, normativa que trouxe de forma expressa o princípio do melhor interesse da criança.

Diante de uma análise paralela entre o desenvolvimento do direito da criança e do adolescente e o desenvolvimento das normativas nacionais, desde a primeira Constituição Federal de 1824 até a Constituição Cidadã de 1988, faz-se essencial entender o lugar que os mesmos ocupavam dentro dos núcleos familiares e da sociedade em geral, visto que por anos os filhos foram literalmente classificados e diferenciados conforme o vínculo advindo de seus genitores.

Eis que, por meio do $\S 6^{\circ}$ do art. 227 da Constituição Federal, todos os filhos naturais, legítimos, ilegítimos, biológicos e adotados, independentemente do meio pelo qual passassem a integrar àquela família, deveriam ser tratados de forma igualitária, possuindo os mesmos direitos desde possuir o nome da família, pleitear alimentos, até os direitos sucessórios.

Sendo assim, diante das diferentes formas de integrar um núcleo familiar, o presente estudo passa a abordar o instituto da adoção, que em paralelo ao direito das crianças e adolescentes se transformou ao longo das décadas, conforme era possível identificar inicialmente por meio do Código Civil de 1916, no qual se exigia que a adoção fosse realizada por um casal unido pelo casamento, sem filhos legítimos e por escritura pública. Após diversas modificações no texto originário do Código Civil de 1916, com o advento da Lei ${ }^{\circ} 4.655$ de 1965 , a adoção passou a ser definida conforme o 
instituto da legitimação adotiva que, posteriormente, foi substituído pela adoção plena e simples, ambas reguladas pelo Código de Menores 1979, até finalmente alcançar a definição trazida pelo ECA em 1990, texto normativo que também sofreu alterações.

Em razão da Lei $\mathrm{n}^{\circ} 12.010$ de 2009, a adoção passou a adquirir caráter excepcional, visto que o ECA priorizou a manutenção da criança na família natural e na extensa, e, como últimas opções, na família substituta (mediante a guarda, tutela e adoção), bem como nas medidas de acolhimento (por meio de instituições, programa de apadrinhamento e das famílias acolhedoras).

Destarte, além de seu caráter excepcional trazido pelo ECA, a adoção também é irrevogável, imprescritível e personalíssima, sendo que para sua ocorrência faz-se essencial a inexistência de poder familiar dos antigos pais e, portanto, é necessário entender os caminhos que levam a essa destituição: o processo judicial altamente litigioso, a morte dos genitores ou a entrega, que infelizmente traz consigo o preconceito do abandono baseado na crença que romantiza de forma exacerbada a maternidade, um preconceito que cega e condena a adoção intuitu personae, tirando da mãe e do pai os seus poderes de escolha e, da criança, a oportunidade de crescer no seio de uma família que a deseje.

Ademais, ressalta-se no presente estudo as diferentes modalidades de adoção, tratando do delicado ponto de diferenciação entre a adoção intuitu personae e a adoção à brasileira, visto que a primeira em nada se equipara à segunda, afinal esta nada mais é do que um crime e a falta de conversa a respeito desse tema, o medo da demora do processo judicial e a busca incessante pela família extensa, culminam no fato de que muitas mães recorrem à ilegalidade, por meio de um ato de desespero.

No presente estudo, a adoção deve ser entendida como um ato de amor e não de caridade, no qual, apesar de o paradigma do afeto ter tomado a frente do Direito das Famílias, ainda não se tornou um instituto muito 
comentado e os maiores prejudicados são os pequenos brasileiros vítimas desse sistema, que não possuem voz ou lugar de fala. Por meio deste buscase desmistificar e explicar aos profissionais de direito, aos candidatos à adoção e a todos aqueles que queiram entender mais sobre o instituto, os caminhos que deverão ser percorridos pelos menores e pelas famílias tanto aquelas que entregam, quanto as que acolhem - comentando sobre a destituição do poder familiar, o acolhimento em suas diferentes formas, a habilitação dos candidatos no âmbito nacional e internacional, o cadastramento no novo SNA, a vinculação dos habilitados com o menor, o estágio de convivência, até o ajuizamento do processo de adoção e o fim do mesmo.

Por meio de um olhar crítico ao ECA, o presente estudo retrata de forma prática esse processo judicial, tentando entender como deveria ocorrer o processamento pelo rito especial repleto de lacunas, dentre os seus prazos, sua prioridade de tramitação, todas as etapas processuais na primeira instância até atingir o fim das etapas recursais. Retratam-se os benefícios e questionam-se as lacunas do Estatuto não resolvidas ou até mesmo advindas das alterações pela Lei $n^{\circ} 12.010$ de 2009 e pela Lei $\mathrm{n}^{\circ} 13.509$ de 2017, perpassando pelas melhorias que poderiam ter sido implantadas por meio de um Estatuto próprio, proveniente do Projeto de Lei do Senado n 394 de 2017 que não se concretizou.

Atualmente, apesar de todas as dificuldades enfrentadas, existem soluções implantadas a fim de solucionar esse cenário, como, por exemplo, o aplicativo A.DOT que incentiva a adoção tardia, os projetos para abrir as portas dos abrigos e os grupos de pós-adoção para lidar com as dificuldades consequentes de qualquer paternidade ou maternidade e que, portanto, auxilia no afastamento do fantasma da devolução.

Deste modo, partindo da premissa do paradigma do afeto e, consequentemente, de que a adoção seria a mais pura ilustração desse sentimento por meio da escolha consciente por uma família, então, todos 
deveriam se sentir adotados na sua infância e adolescência, todos deveriam se sentir parte de um grupo familiar e perceber que possuem seu lugar na sociedade. A busca incessante por famílias extensas que culminam no crescimento dos menores nos abrigos e, posteriormente, nas dificuldades de adoções tardias, bem como a falta de recursos de diversas varas especializadas, as lacunas normativas, a idealização dos candidatos por um perfil em específico do filho e o entendimento arcaico de não abrir as portas dos abrigos aos candidatos, configuram barreiras que não podem ser analisadas por um viés minimalista de culpabilização exclusiva de um setor.

O presente estudo tentou dar voz aos menores brasileiros acolhidos na espera de um lar cercado de segurança, que sabem explicar melhor do que muitos o motivo de existirem mais famílias aptas à adoção do que crianças acolhidas e que permanecem sem serem adotados, que veem sua adolescência virar maioridade sem possuírem um lar, que pagam com suas próprias vidas um fardo do qual não possuíram qualquer ingerência e que esperam diariamente a chegada de uma família que corresponda a maior expectativa: serem amados. 


\section{A EVOLUÇÃO DO DIREITO DA CRIANÇA E DO ADOLESCENTE}

A criança e o adolescente nem sempre foram compreendidos como sujeitos de direito civis, tampouco como uma parcela vulnerável da população pela sua condição de desenvolvimento, tendo sido a proteção inerente a esses sujeitos de direito o resultado de um longo processo para o reconhecimento de direitos.

Esse processo doutrinariamente costuma ser divido em três etapas, sendo a primeira a "Doutrina Penal do Menor", posteriormente a "Doutrina da Situação Irregular" e, por último, a vigente "Doutrina da Proteção Integral”.

A primeira fase, a Doutrina do Menor, era baseada em um direito penal direcionado pelos Códigos Penais de 1830 e 1890, leis que influenciaram diretamente a criação do Código de Menores de 1927 - o Código Mello Mattos - no qual as crianças e os adolescentes eram vistos exclusivamente sobre a ótica da delinquência ${ }^{1}$, de forma que ficavam vulneráveis a um Estado Punitivo, conforme exposto em seu art. $1^{\circ}$ :

"O menor, de um ou outro sexo, abandonado ou delinquente, que tiver menos de 18 annos de idade, será submettido pela autoridade competente ás medidas de assistencia e protecção contidas neste Codigo.",

Com o advento do segundo Código de Menores de 1979, que revogou o Código Mello Mattos, se instaurou a segunda etapa conhecida como Doutrina da Situação Irregular que não se responsabilizou por alterar significativamente a visão da criança e do adolescente na etapa da Doutrina

1 FONSECA, Antonio Cezar Lima da. Direito da Criança e do Adolescente. São Paulo: Atlas S.A., 2011. p. 7

2 Código dos Menores, decreto $\mathrm{n}^{\circ}$ 17.943-a de 12 de outubro de 1927. Disponível em <http://www.planalto.gov.br/ccivil_03/decreto/1910-1929/D17943A.htm〉. Acesso em 10 de nov de 2019 . 
do Menor. Essa etapa utilizava o argumento da defesa e do superior interesse do menor para justificar a aplicação de medidas repressivas - de prática diversa das medidas educativas -, inclusive classificando seis categorias de situações especiais, presentes no art. $2^{\circ}$ do referido Código, as quais poderiam levar o menor a uma marginalização mais ampla, visto que considerava o abandono material um passo para marginalidade.

As decisões tomadas por juízes nessa etapa se davam de maneira totalmente subjetiva, arbitrária e espelhando uma discriminação social, de forma que o juiz não julgava o menor, mas definia a sua situação irregular e, consequentemente, aplicava medidas terapêuticas ${ }^{3}$ como a internação que em nada auxiliava essas crianças, mas apenas ocasionava a manutenção do status quo. O Código de Menores de 1979, portanto, não amparava todas as crianças da sociedade brasileira, mas apenas aquelas que cometiam atos infracionais ou que viviam em situações caracterizadas por problemas sociais.

Ocorre que, com o avanço dos anos, o tema do direito da criança se tornou um tema relevante no cenário internacional e em 1948 com a Declaração Universal dos Direitos Humanos se reconheceu pela primeira vez, de forma universal, que a criança deveria ser objeto de cuidados e atenções especiais, conforme estabelecido no item 2 do artigo 25:

"A maternidade e a infância têm direito a cuidados e assistência especial. Todas as crianças nascidas dentro ou fora do matrimônio gozarão da mesma proteção social",

Outros pactos internacionais que tratavam do tema de direitos humanos foram influenciados pelo disposto na Declaração Universal dos

3 LARA, Camila Orofino de. A adoção da criança à luz da proteção integral, com ênfase na modalidade póstuma. Rio Grande do Sul, 2012. Trabalho de conclusão de curso para obtenção do grau de Bacharel em Ciências Jurídicas e Sociais pela Pontifícia Universidade Católica do Rio Grande do Sul. Disponível em <http://www.pucrs.br/direito/wpcontent/uploads/sites/11/2018/09/camila_lara.pdf>. Acesso em 23 set. 2019, apud AMARAL E SILVA, Antonio Fernando. O mito da Imputabilidade Penal e o Estatuto da Criança e do Adolescente (Trabalho monográfico no site da ABMP). Disponível em: 〈www.abmp.org.br〉, 1998. Acesso em: 19 ago. 2012.

4 Declaração Universal dos Direitos Humanos. Disponível em <https://www.ohchr.org/EN/UDHR/Pages/Language.aspx?LangID=por>. Acesso em 10 nov 2019. 
Direitos do Homem de 1948 e foi também, baseado nessa declaração que houve a elaboração do primeiro texto a tratar exclusivamente da proteção de crianças - ressaltando que estas últimas são definidas internacionalmente como todos aqueles menores de 18 anos de idade -, a Declaração Universal dos Direitos da Criança editada em $1959^{5}$ e que contém 10 princípios que devem ser universalmente respeitados para que as crianças possam viver com dignidade, carinho e respeito:

\footnotetext{
Princípio $1^{\circ}$

A criança gozará todos os direitos enunciados nesta Declaração. Todas as crianças, absolutamente sem qualquer exceção, serão credoras destes direitos, sem distinção ou discriminação por motivo de raça, cor, sexo, língua, religião, opinião política ou de outra natureza, origem nacional ou social, riqueza, nascimento ou qualquer outra condição, quer sua ou de sua família.
}

Fato incontroverso é o de que a Declaração Universal dos Direitos da Criança passou a nortear a atuação do Direito Internacional Público e Privado, abrindo o caminho para que em 20 de novembro de 1989 a ONU adotasse por unanimidade a Convenção dos Direitos das Crianças, que contém 54 artigos divididos por quatro categorias de direito: direito à sobrevivência, direitos relativos ao desenvolvimento, direitos relativos à proteção e direito de participação.

O Brasil ratificou a supracitada convenção em 21 de novembro de 1990, de forma que a normativa internacional passa a ser um vínculo com o Brasil que teve a obrigação de adequar às normas de direito interno aos da norma internacional, por meio do Decreto n ${ }^{\circ} 99.710$ de 1990.

Nesse cenário de evolução internacional se ampara a terceira e última fase dos direitos da criança e do adolescente no Brasil, a da Doutrina da Proteção Integral, responsável por trazer à luz as crianças e os adolescentes como os sujeitos de direitos civis. Essa nova fase foi influenciada diretamente pelo princípio contido no fim do art. 3.1 da Convenção dos Direitos da Criança que em seu texto original dispõe: "In

5 CÁPUA, Valdeci Ataíde. Adoção Internacional: procedimentos legais. $1^{\mathrm{a}}$ ed. (ano 2009), $2^{\mathrm{a}}$ reimpr.. Curitiba: Juruá, 2012, p. 45 e 46. 
all actions concerning children, whether undertaken by public or private social welfare institutions, courts of law, administrative authorities or legislative bodies, the best interests of the child shall be a primary consideration", cujo trecho em negrito é traduzido ao português como "o melhor interesse da criança"

Essa tradução dá ensejo a dois conceitos interpretativos diversos: primeiramente o conceito qualitativo - o melhor interesse da criança - ou um conceito quantitativo - o maior interesse da criança. De acordo com a doutrinadora Tânia da Silva Pereira, no Brasil se optou pelo conceito qualitativo - melhor interesse - ao levar em consideração a orientação constitucional, infraconstitucional e o sistema jurídico brasileiro. ${ }^{7}$

Além da convenção, existiram duas normas essenciais que forma marcos influenciadores da Doutrina da Proteção Integral, a Constituição da República Federativa do Brasil de 1988 - em seu artigo $227^{8}$ - e, posteriormente, o Estatuto da Criança e do Adolescente de 1990 principalmente em seus artigos $3^{\circ}, 4^{\circ}$ e $5^{\circ}$.

Deixando de lado o termo "menor" que carregava consigo a idéia pejorativa de crianças e adolescente que cometiam atos ilícitos decorrentes da primeira e segunda fase aqui apontadas, a terceira fase substitui o "direito do menor" para o "Direito da Criança e do Adolescente", tendo como fundamentações a visualização da criança como sujeito de direitos, a infância como fase especial do processo de desenvolvimento e a prioridade

\footnotetext{
${ }^{6}$ PEREIRA, Tânia da Silva. O princípio do "melhor interesse da criança": da teoria à prática. Disponível em <https://www.gontijofamilia.adv.br/2008/artigos_pdf/Tania_da_Silva_Pereira/MelhorInteresse.pdf $>$, acesso em 30 out. 2019, p. 291.

7 Ibid. p. 291 e 292.

8 Art. 227. É dever da família, da sociedade e do Estado assegurar à criança, ao adolescente e ao jovem, com absoluta prioridade, o direito à vida, à saúde, à alimentação, à educação, ao lazer, à profissionalização, à cultura, à dignidade, ao respeito, à liberdade e à convivência familiar e comunitária, além de colocá-los a salvo de toda forma de negligência, discriminação, exploração, violência, crueldade e opressão.
} 
absoluta a essa parcela da população diante da sua fragilidade e sua condição de pessoa em desenvolvimento. ${ }^{9}$

Portanto, nessa última fase as crianças adquiriram o status de sujeitos de direitos fundamentais, alvos da proteção integral que deveria vir da família e também do Estado e da Sociedade, ou seja, esses pequenos sujeitos de direito não poderiam em hipótese alguma serem esquecidos e se tornarem alvos de qualquer tipo de negligência particular ou pública. 


\section{A EVOLUÇÃO DAS NORMATIVAS BRASILEIRAS NO DIREITO DA CRIANÇA E DO ADOLESCENTE}

As três etapas percorridas pelo direito da criança e do adolescente foram o resultado de uma mudança social, política e ideológica tanto nacional quanto internacional, de forma que a legislação brasileira acompanhou este movimento muitas vezes se adaptando a nova etapa já instituída e outras sendo o marco inicial da nova forma de pensamento.

Apesar do avanço, a atenção e cuidado às crianças e adolescentes nem sempre esteve disposto nas normas brasileiras, como por exemplo, no texto da nossa primeira Constituição de 1824 - elaborada na época do Brasil Império - na qual não se dedicou nenhuma linha do texto para os direitos dos jovens brasileiros. Esse tratamento omisso se repetiu também na nossa segunda Constituição de $1891^{10}$, quando o Brasil já tinha se tornado uma República Federativa, abolido a escravatura, transferido o eixo de vida predominantemente rural para um eixo urbano e passado a adotar o sistema de separação dos poderes executivo, judiciário e legislativo.

A primeira Carta Magna a tratar do tema foi a Constituição Federal de 1934, entretanto de forma restritiva, apontando apenas sobre o direito da criança em relação (i) ao trabalho infantil - no qual proibiu os menores de quatorze anos de idade de trabalhar, bem como proibiu o trabalho noturno aos menores de dezesseis anos e o trabalho insalubre em indústrias aos menores de dezoito anos - e dispôs sobre (ii) os serviços de amparo à maternidade e à infância ${ }^{11}$.

Após três anos desse contato inicial com a temática, na quarta Constituição Federal da República Federativa do Brasil que entrou em vigor no ano de 1937, a proteção às crianças foi ampliada de forma que passou a tratar primordialmente daquelas mais carentes e estabeleceu como obrigação do Estado a assistências as mesmas, assegurando condições

10 CÁPUA, Valdeci Ataíde. Op. cit. p. 36.

11 Ibid., p. 36. 
físicas e morais para o seu desenvolvimento, repetindo as regras da Constituição Federal de 1934 relativas às proibições de trabalho de menores de idade e conferindo a possibilidade de que pais sem condições financeiras pudessem requerer auxílio do Estado para a subsistência e criação dos seus filhos.

Além disso, a Carta Magna de 1937 também tratava dos deveres dos entes federados para com as crianças e adolescentes, da criação de instituições de ensino público para aqueles que não tivessem condições de estudarem em escolas particulares e foi pelo Decreto-Lei 3.779/41 que foi criado o Serviço de Assistência aos Menores (SAM), cujo objetivo era amparar os menores pejorativamente classificados como "desvalidos" e "infratores" em todo o território nacional. ${ }^{12}$

Cabe ressaltar que todas essas mudanças legislativas ocorreram no curso da primeira etapa do direito das crianças no direito brasileiro, a da Doutrina do Penal do Menor. Nesse sentido, como as últimas alterações legislativas referentes à primeira etapa, surgiu a Constituição Federal de 1946 que manteve as mesmas disposições anteriores das Constituições anteriores e, no ano de 1964, foi criada a Fundação Nacional do Bem-Estar do Menor (FUNABEM) pela Lei $\mathrm{n}^{\circ} 4.531 / 64$, instituição que substituiu o SAM (Serviço de Assistência aos Menores) - criado em 1941 para prestar amparo aos menores "desvalidos" e infratores em todo território nacional e que trouxe uma proposta de fazer com que toda criança abandonada deixasse de ser preocupação exclusivas de entidades privadas e órgãos estatais para passar a fazer parte da própria política do Estado. ${ }^{13}$

Posteriormente, diante da Ditadura Militar Brasileira ocorreu a imposição da Carta Magna de 1967 que em pleno golpe passou a prever a assistência à maternidade, obrigando empresas comerciais, industriais e agrícolas a oferecerem ensino primário gratuito aos empregados e seus 
filhos, com a garantia de fornecimento de aprendizagem, em cooperação, aos menores trabalhadores ${ }^{14}$; bem como ensino obrigatório e gratuito para crianças entre sete e quatorze anos. Além disso, foi editada a primeira Emenda Constitucional, a $\mathrm{n}^{\circ} 1$ de 1969 , estabelecendo que "crianças extraordinárias" também teriam acesso à educação que seria regulamentada por lei especial.

Destarte, de forma a inaugurar o início da segunda etapa, a da Doutrina da Situação Irregular, o ano de 1979 foi declarado como o Ano Internacional da Criança, instituindo o novo Código de Menores - em substituição ao Código de Menores de 1929 - que conceituou o menor abandonado e estabeleceu as medidas específicas apenas àquela parcela de crianças que deveriam ser cuidadas pelo Estado diante das situações de carência decorrentes dos abandonos, de falta ou mau relacionamento com sua família, com a sociedade e com as regras. ${ }^{15}$

Somente no ano de 1988 com o advento da Constituição Cidadã que os direitos das crianças e adolescentes passaram a existir em sua maior amplitude de garantias e direitos fundamentais, desde o preâmbulo desse texto normativo, alternando entre sua forma implícita e explícita, encontrase normas preocupadas em entregar aos cidadãos os direitos que nos últimos 20 anos lhe tinham sido tirados, tanto os coletivos quanto os individuais.

Nesse período dos anos 80 surge a terceira etapa dos direitos das crianças e dos adolescentes, a Doutrina da Proteção Integral, que se difundiu com a Constituição Cidadã passando a abranger explicitamente os limites sobre o trabalho e profissionalização, capacidade eleitoral, assistência e seguridade social, programação de rádio e televisão, deveres

14 No ano de 1967 o Decreto-Lei 229 reduz a idade mínima dos aprendizes de 14 anos estabelecido pelo Decreto Lei 5.452 no governo do presidente Getúlio Vargas - para os 12 anos. Disponível em <http://www.planalto.gov.br/ccivil_03/decreto-lei/Del0229.htm〉. Acesso em 10 nov 2019.

15 CÁPUA, Valdeci Ataíde. Op. cit., p. 37. 
do Estado, garantias democráticas processuais, incentivo à guarda, prevenção contra entorpecentes, defesa contra o abuso sexual, estímulo à adoção desvinculada da idéia simplória de manutenção de laços patrimoniais, dentre outras mudanças referentes às nossas crianças e adolescentes brasileiros, sem distinção de classe social, raça, gênero ou etnia. $^{16}$

Diante de todo o movimento internacional protecionista iniciado nos anos 80 e dos avanços normativos e doutrinários brasileiros, após dois anos da Constituição Federal de 1988 foi criado o Estatuto da Criança e do Adolescente por meio da lei $\mathrm{n}^{\circ} 8.069$ de 13 de julho de 1990 que ab-rogou o Código de Menores de 1979 e trouxe inúmeras alterações, conforme será exposto adiante. 


\section{OS FILHOS DAS DIFERENTES DÉCADAS}

As sociedades em seus estágios mais primitivos foram formadas inicialmente por uniões de famílias que diante do tempo iam se tornando cada vez mais numerosas, formando assim as comunidades que se multiplicavam até chegarmos ao contexto atual. Nessas famílias as questões privadas de cada um dos núcleos não mantinham relações com o Estado e eram resguardadas apenas em âmbito privado ${ }^{17}$.

Nessa caminhada evolutiva notoriamente marcada pelo forte poder patriarcal, a família tinha no homem a figura de um pater familiae, única figura familiar com poder sob todos os membros que se concretizava na família direta por meio de alguns poderes, dentre eles pelo pátria potestas poder para com os descendentes - ou pelo potestas maritalis - poder para com as esposas ${ }^{18}$.

Essa organização derivava de um interesse estatal e religioso, este último que determinava o casamento como única estrutura de convívio conjugal moralmente aceita e tinha seu sacramento regido pelas leis eclesiásticas, que a fim de fidelizar seus seguidores desde o princípio da vida passou a converter os mesmos em práticas de batismo ainda quando recém-nascidos.

O pátrio poder fortemente defendido pelo Estado e pela religião, era tamanho que nas origens das famílias greco-romanas, caso as esposas dessem a luz a filhos com alguma deficiência física ou mental, os pais de família poderiam por meio do ius exponendi abandonar o bebê ainda recémnascido em virtude de possuir alguma característica à época identificada como "deformação", de forma a propiciar uma seleção eugênica cujo

17 DIAS, Maria Berenice. Filhos do afeto: questões jurídicas. São Paulo: Revista dos Tribunais, 2016, p. 20.

18 CÁPUA, Valdeci Ataíde. Op. cit., p. 59. 
entendimento era de que tal ato era realizado em prol de beneficiar sua própria comunidade ${ }^{19}$.

Nesse contexto matrimonial extremamente machista e preconceitusos, um dos principais papéis das esposas era o de ser mãe, sendo normal nos primórdios do instituto do casamento que as mulheres incapazes de gerar filhos ocasionassem a possibilidade do homem de anular aquele casamento, mas num extremo oposto, caso a esterelidade fosse masculina, o casamento não poderia ser rompido e a mulher deveria manter relações sexuais até com outro parente, a fim de possibilitar assim a continuidade dos ritos religiosos e garantir a segurança patrimonial.

Sendo assim, o filho resultante da união da esposa de um marido estéril com outro parente, era declarado com filho direto do marido da genitora, afinal o pai jurídico se sobrepunha ao pai biológico, derivado do pátrio poder ${ }^{20}$.

Portanto, uma espécie de seleção entre filhos sempre ocorreu ao longo da história e apesar de terem carregado diferentes justificativas continuidade dos cultos religiosos, segurança patrimonial, pressão social e até o simples desejo de constituir a família perfeita - é perceptível que no âmago dessas seleções existia um motivo comum: o preconceito para com algo definido como diferente por crenças sociais, morais e religiosas.

A idéia de que uma família perfeita advém de um casamento perfeito com filhos perfeitos está enraizada em diferentes culturas e no Brasil, por exemplo, a influência do moralismo religioso era tamanho que apenas após a Proclamação da República, no ano de 1890, que o casamento passou a ser regulado pelo Estado e não mais pela Igreja Católica. Nesse contexto, o casamento passou a ser regido sob o regime da comunhão universal de bens no qual se formava um laço conjugal/matrimonial indissolúvel entre o casal, rigidez essa que não se dava apenas entre os cônjuges, mas também para 
com os filhos, que eram resultado direto das uniões legitimas e sacramentadas pelo Estado.

Ocorre que, obviamente, os filhos não necessariamente eram concebidos apenas no seio de uma relação conjugal moralmente aceita, e àqueles derivados das uniões não sacramentadas, consideradas moralmente indevidas, passaram a ser considerados ilegítimos.

Sendo assim, os filhos eram classificados conforme o vínculo existente entre os seus pais, podendo ser considerados os filhos legítimos, os naturais ou os ilegítimos. Os primeiros eram aqueles oriundos de uma união constituída pelo casamento e podiam ser reconhecidos e registrados sem nenhum impasse pelos seus genitores. Ainda como vestígio dessa época, momento em que a manutenção da família moralmente e religiosamente aceita era tão imperiosa, o reconhecimento da paternidade se dava por presunção desde que os genitores fossem casados, entendimento que, pasmem, continua formalizado até os dias atuais por meio do artigo 1.597 do Código Civil.

As outras duas classificações, os filhos naturais e os ilegítimos, derivavam de um preconceito social que faziam uso de adjetivos altamente discriminatórios e tratavam tais crianças e adolescentes como a margem da sociedade. Os primeiros, os filhos naturais, eram aqueles cujos genitores não eram cassados, e, caso pelo menos um dos pais fosse casado o filho se enquadrava na segunda classificação, a dos filhos ilegítimos, espúrios ou bastardos. $^{21}$

Ocorre que esse tratamento desequilibrado entre os filhos persistiu décadas de forma que a prole legítima podia ser reconhecida pelos genitores, poderia ser registrados nos respectivos Registros Civis passando a possuir o sobrenome do pai, bem como requerer ao genitor alimentos e perceber os seus direitos sucessórios. Ao passo que os filhos considerados

${ }^{21}$ DIAS, Maria Berenice. Op. cit., p. 21 
ilegítimos e naturais não podiam ser registrados no nome dos genitores e não tinham qualquer direito em relação ao pai, não podiam buscar alimentos e nem participavam de sua sucessão.

Apenas no ano de 1942 foi admitido que os filhos naturais pudessem ser registrados pelo genitor, desde que respeitassem a condição de que os pais fossem desquitados - instituto jurídico arcaico e anterior ao divórcio, cuja conotação adquiriu um caráter altamente pejorativo e que determinava a separação entre os cônjuges e os bens, mas o Estado os obrigava a manter eternamente os laços matrimoniais -, não bastando que apenas um deles estivesse separado de fato. ${ }^{22}$

Nessa crescente, conforme anteriormente abordado, foi apenas no ano de 1988 junto à Constituição Cidadã e a Doutrina da Proteção Integral, que o tratamento entre os filhos sofreu uma revolução, no qual se proibiu qualquer referência discriminatória entre os mesmos e todos passaram a ser considerados iguais perante o Estado, independente da sua filiação:

“Art. 227. É dever da família, da sociedade e do Estado assegurar à criança, ao
adolescente e ao jovem, com absoluta prioridade, o direito à vida, à saúde, à
alimentação, à educação, ao lazer, à profissionalização, à cultura, à dignidade, ao
respeito, à liberdade e à convivência familiar e comunitária, além de colocá-los a
salvo de toda forma de negligência, discriminação, exploração, violência,
crueldade e opressão. $(\ldots)$

$\S 6^{\circ}$ Os filhos, havidos ou não da relação do casamento, ou por adocão, terão os mesmos direitos e qualificacões, proibidas quaisquer designacões discriminatórias relativas à filiação." (grifo nosso)

O referido parágrafo finalmente toma a frente de um instituto responsável pela inserção de filhos no seio familiar de forma diferente da biológica e que desde os primórdios do instituto da família estão presentes na sociedade (tanto pela motivação religiosa, patrimonial e sucessória até pelos mais sinceros laços afetivos), mas que nem sempre teve a atenção necessária, o instituto da adoção. No antigo Império Romano, por exemplo, 
época na qual não se discutia sobre a proteção da criança, mas apenas se respeitava a autoridade do pai, a adoção surgiu como um instrumento de poder familiar com três objetivos principais: primeiramente o de escolher um sucessor (visto que a maior parte dos adotados eram adultos), o de permitir a ascensão social de um indivíduo e o de dar descendentes a quem não o tinha ${ }^{23}$.

O instituto da adoção é perfeitamente descrito pelo ilustre jurista Caio Mário da Silva Pereira como “(...) o ato jurídico pelo qual uma pessoa recebe outra como filho, independentemente de existir entre elas qualquer relação de parentesco consangüíneo ou afim" (2018, pg 470) ${ }^{24}$ e no Brasil tal instituto foi introduzido com as Ordenações Filipinas e a Lei de 22/09/1828, segundo retrata Maria Luiza Marcílio. ${ }^{25}$

Infelizmente, desde a época da colonização existiam relatos do abandono de recém-nascidos, prática introduzida pelos portugueses diante das suas experiências européias e medievais, visto que a população originária do território brasileiro, os índios, não abandonavam os seus filhos. Nesse novo contexto de abandono colonial, conforme ressalta a autora Maria Luiza Marcílio, também foi copiada do modelo europeu a "Roda dos Expostos",

Tal roda surgiu em Salvador no ano de 1726, criada pela Irmandade da Santa Casa de Misericórdia, e se tratava de um cilindro oco que girava em torno de seu próprio eixo com duas aberturas, a primeira voltada para rua e a segunda voltada para o local do acolhimento, no qual a pessoa deixava a criança na abertura externa - da rua -, tocava uma sineta e uma

23 CÁPUA, Valdeci Ataíde. Op. cit., p. 64.

24 PEREIRA, Caio Mário da Silva. Instituições de Direito Civil (volume V) - Direito de Família, $26^{\mathrm{a}}$ ed.. Rio de Janeiro: Editora Gen e Forense, 2018, p. 470.

25 MARCÍLIO, Maria Luiza. História social da criança abandonada. São Paulo: Hucitec, 1998, p. 12.

26 Ibdi, p. 12. 
religiosa girava o cilindro para a direção da abertura voltada para o interior da casa de acolhimento e, assim, resgatava a criança ${ }^{27}$.

Apesar desse notório abandono infantil e da prática do instituto da adoção desde o Brasil Colônia, seu tratamento por textos jurídicos era raro até que ganhou espaço no Código Civil de 1916, cujos artigos 368 a 378 regulamentavam a adoção de forma rigorosa na qual somente podiam adotar os maiores de 50 anos, sem filhos legítimos ou legitimados e a adoção por duas pessoas só poderia ocorrer se elas fossem casadas entre si. Além disso, o vínculo poderia ser dissolvido, conforme o artigo 374, por meio da resilição unilateral por parte do adotado quando completasse 18 anos, se convencionado entre as partes e pela ingratidão cometida pelo adotado contra o adotante.

Esse texto normativo determinava que a adoção poderia ser formalizada por via cartorial, como um simples negócio jurídico, de forma pouco formal na qual o artigo 375 determinava que a adoção deveria ser realizada por escritura pública, não sujeita a condição ou termo ${ }^{28}$.

Posteriormente, apesar da tendência natural à evolução, o Código de Menores de 1927 não trouxe nenhuma alteração ao instituto, dado que, conforme anteriormente exposto, esse diploma legal se ateve ao tema das soluções penais resultantes do abandono físico e moral de uma parcela restrita das crianças e adolescentes brasileiras, aqueles conhecidos como delinquentes.

Com o passar do tempo, a Lei 3.133 de 1957 trouxe algumas alterações para os artigos 368, 369, 372, 374 e 377 do Código Civil de 1916, mesmo distante de ser a lei perfeita para os cuidados e proteção das crianças e adolescentes brasileiros, reduziu a idade mínima para adoção de

27 FONSECA, Antonio Cesar Lima da. Direitos da Criança e do Adolescente. São Paulo: Atlas S.A., 2011, p.138.

28 Código Civil de $1916 . \quad$ Disponível em <http://www.planalto.gov.br/ccivil_03/LEIS/L3071.htm>. Acesso 10 nov 2019. 
50 anos para 30 anos, bem como a diferença de idade entre o adotante e adotado para 16 anos.

Além disso, a Lei 3.133 acrescentou ao artigo 368 um parágrafo único que determinava que as pessoas casadas só poderiam adotar após 5 (cinco) anos do casamento e também alterou o caput do referido artigo retirando a exigência de que o adotante só pudesse adotar caso não tivesse prole legítima ou legitimada.

Apesar dos referidos avanços, a nova lei manteve a discriminação entre os irmãos de forma que quando o adotante possuísse filhos legítimos, legitimados ou reconhecidos ele até poderia adotar, mas o filho adotado não poderia participar de sua sucessão ${ }^{29}$. De forma intrigante o Código Civil de 1916 perdurou com a mentalidade de não realizar o rompimento do laço do adotado para com sua família natural, de forma que o mesmo poderia manter o nome da família de sangue, bem como o artigo 378 determinava que os direitos e deveres que resultassem do parentesco natural não se extinguiriam pela adoção, exceto o pátrio poder.

Após oito anos, em virtude da Lei 4.655 de 1965, um novo instituto foi trazido ao direito brasileiro, o da legitimação adotiva, que trazia efeitos mais profundos e duradouros do até então instituto de adoção. A legitimação adotiva necessitava da outorga judicial, não se tratava de ato simples que poderia ser realizado no cartório, e constituía ato irrevogável diferentemente da adoção até então em vigor no Código Civil que poderia ser dissolvida conforme vontade das partes ${ }^{30}$.

Enquanto a adoção era possível para indivíduos maiores ou menores de idade, a legitimação adotiva era admita primordialmente às crianças até

29 Art. 377. "Quando o adotante tiver filhos legítimos, legitimados ou reconhecidos, a relação de adoção não envolve a de sucessão hereditária" da Lei o 3.133, de 8 de maio de 1957. Disponível em < http://www.planalto.gov.br/ccivil_03/leis/1950-1969/L3133.htm>. Acesso em 10 nov 2019. 30 CHAVES, Antônio. A Legitimação Adotiva, Forma Mais Avançada de Integração de Crianças Abandonadas ou Expostas, em Lares Substitutos. Diferenças, Inconvenientes e Vantagens com Referência à Adoção, $\quad$ p. 5 Disponível em < https://www.revistas.usp.br/rfdusp/article/download/66528/69138>. Acesso em 23 set. 2019. 
sete anos de idade que fossem expostas, abandonadas, ou se encontrassem em posição equivalente.

Além disso, a legitimação adotiva foi o primeiro instituto que promoveu um total desligamento da família de sangue, ao passo que na adoção até então permaneciam alguns vínculos com a família de origem e, portanto, a possibilidade de conservar o nome, de suceder, de pedir e de prestar alimentos ${ }^{31}$.

No que se refere à discriminação entre os filhos, esta foi apaziguada ao determinar que o filho adotado permanecia com os mesmos direitos e deveres do filho legítimo, salvo no caso de sucessão no qual concorresse com filho legítimo superveniente à adoção. Ademais, para que a adoção surtisse efeito quanto aos ascendentes do adotante era necessário a anuência dos mesmos trazendo, assim, a possibilidade de extensão dos efeitos jurídicos:

Art. $9^{\circ} \mathrm{O}$ legitimado adotiva tem os mesmos direitos e deveres do filho legítimo, salvo no caso de sucessão, se concorrer com filho legítimo superveniente à adoção

$\S 1^{\circ} \mathrm{O}$ vínculo da adoção se estende à família dos legitimantes, quando os seus ascendentes derem adesão ao ato que o consagrou.

$\S 2^{\circ}$ Com a adoção, cessam os direitos e obrigações oriundos, da relação parentesco do adotado com a família de origem.

Essa nova lei referente à legitimação adotiva trouxe um olhar mais cuidadoso à criança e tornava legítima a adoção dos "infantes" expostos, cujos pais fossem desconhecidos ou declarassem por escrito concordar com o ato; do menor de 7 (sete) anos de idade, cujos pais tivessem sido destituídos do pátrio poder; do filho cuja mãe não tivesse possibilidade de prover a sua criação. As crianças maiores de 7 (sete) anos de idade poderiam ser adotadas quando à época já se encontrassem sob a guarda dos

31 Ibdi., p. 6 e 7 acesso em 23 set. 2019. 
legitimados por no mínimo 3 (três) anos, mesmo que estes não preenchessem as condições exigidas.

Ainda em razão da Lei 4.655 o processo passou a ser judicial e formalmente previsto em seu artigo $5^{\circ}$ no qual era definida a documentação que deveria acompanhar a petição inicial (certidão de casamento, atestado de residência, folha de antecedentes, prova de idoneidade moral e financeira, dentre outros documentos), determinava a participação dos membros do Ministério Público para observar as conveniências do menor, de seu futuro e bem-estar, previa a possibilidade de recursos e determinava que o procedimento deveria ocorrer sobre segredo de justiça, sob risco de consequiências no âmbito penal aos envolvidos no descumprimento.

Por fim, a referida lei ainda instituiu que a legitimação adotiva se tratava de ato irrevogável, ainda que aos adotantes viessem a nascer filhos legítimos, aos quais estão equiparados os legitimados adotivos com os mesmos direitos estabelecidos em lei, exceto ao que se referem os direitos sucessórios, conforme anteriormente exposto.

No ano de 1979, a Lei 4.655 foi revogada pela Lei 6.697 de 1979, conhecida como Código de Menores de 1979, que passou a admitir duas formas de adoção, a adoção simples e a adoção plena, esta última que veio com intuito de substituir a legitimação adotiva.

A adoção simples era apontada nos artigos 27 e 28 que se restringiam a prever sua aplicação aos menores em situação irregular, a necessidade de autorização judicial e o estabelecimento de estágio de convivência do menor com os adotantes ou a sua dispensa, de forma que seu procedimento era previsto em outro Código, na lei civil para o qual os referidos artigos do Código de Menor faziam referência.

Já a adoção plena estava prevista nos artigos 29 a 37 e 107 a 109 do Código, no qual estava determinado de forma detalhada o procedimento a ser adotado nessa modalidade, sem que fosse necessário fazer referência à 
lei civil. Esse tipo de adoção atribuía à criança o status de filho do adotado, rompendo qualquer laço com a família natural (ressalvando os impedimentos matrimoniais) e preservou muitas das características da legitimação adotiva, entretanto, inovou no aspecto da separação de fato entre os adotantes, no qual seria permitido a continuação da adoção desde que já tivesse começado o estágio de convivência de 3 (três) anos e acordassem sobre a guarda do menos após a separação judicial.

Após os trâmites judiciais o juiz era encarregado de decidir, conforme o artigo 109 do Código de Menores de 1979 sobre o modelo de adoção a ser aplicado no caso concreto:

Art. 109. Apresentado o relatório de sindicância e efetuadas outras diligências reputadas indispensáveis, após ouvir o Ministério Público, a autoridade judiciária decidirá em cinco dias.

$\S 1^{\circ}$ Autorizada a adocão simples, com a designação de curador especial, será expedido alvará contendo a indicação dos apelidos de família que passará o menor

a

usar.

$\S 2^{\circ}$ Decretada a adocão plena, será expedido mandado para o registro da sentença e o cancelamento do registro original do adotado, nele consignando-se todos os dados necessários, conforme disposto nos arts. 35 e 36 desta Lei.(grifo nosso)

Sendo assim, a adoção simples não tinha poder de romper os vínculos da família de origem, sendo possível apenas a adoção dos nomes dos adotantes sem que outros fossem retirados e o vínculo se restringia apenas a estes, ao passo que na adoção plena o vínculo originário era dissolvido e poderia ter seus efeitos estendidos aos avós e outros parentes.

Nesta esteira temporal, desde o início do aprofundamento do tema com o Código Civil de 1916 até o Código de Menores de 1979, viram-se normativas centradas no homem - como marido e chefe de família -, no poder familiar, desprestigiando o papel da mulher e da criança no seio das famílias brasileiras, sujeitos sobre os quais recaiam muitos mais deveres do que direitos. Ocorre que, com as transformações existentes no cenário político internacional na década de 80 advieram mudanças no cenário jurídico no qual os direitos humanos ganharam espaço e força por meio da 
Declaração Universal dos Direitos Humanos em 1948, que conforme anteriormente exposto foi a porta de entrada para discussões que originaram a Declaração Universal dos Direitos da Criança em 1959 e da Convenção das Nações Unidas sobre os Direitos das Crianças, a qual determinou que “(...) os direitos humanos da criança fossem observados”.

Sendo assim, em meio a esta revolução que a Constituição da República de 1988 assume as rédeas para questionar e colocar em prática a responsabilização social da população brasileira. A Carta Magna não mais defende a união matrimonial como única forma de formação familiar e baseada nos princípios da dignidade da pessoa humana e da igualdade afastou qualquer tipo de discriminação no instituo da adoção e afastou as formas taxativas de família para aquelas derivadas do afeto, elo norteador da família brasileira.

Em 1990, dois anos após a Constituição Cidadã surge o Estatuto da Criança e do Adolescente que juntos se tornam responsáveis pelo fim da duplicidade de adoções previstas pelo Código de Menores de 1979, firmando uma única concepção sobre adoção, com direitos iguais entre os filhos - que adquiriu uma eficácia imediata e retroativa, alcançando inclusive adoções anteriores -, conforme prevê o artigo 20 do ECA:

Art. 20. Os filhos, havidos ou não da relação do casamento, ou por adoção, terão os mesmos direitos e qualificações, proibidas quaisquer designações discriminatórias relativas à filiação. ${ }^{32}$

32 Estatuto da Criança e do Adolescente, lei no 8.069, de 13 de julho de 1990. Disponível em < http://www.planalto.gov.br/ccivil_03/leis/18069.htm>. Acesso em 10 nov 2019. 


\section{DA PREVALÊNCIA DA FAMÍLIA NATURAL À EXCEPCIONALIDADE DA ADOÇÃO}

O Estatuto da Criança e do Adolescente surgiu como um raio de luz e esperança na proteção dos pequenos brasileiros, entretanto, ingênuo seria acreditar que tal normativa nasceu completa e conseguiu abranger desde o princípio toda a segurança que essa parcela da população necessita. A realidade é que a sociedade mudou, permanece mudando e continuará nesse caminho evolutivo, de forma que o direito não pode ser estático e deve a cada momento buscar as alterações necessárias numa busca diária para atingir o melhor resultado.

Neste caminho evolutivo também se encontra o instituto da adoção à luz do ECA com todas as alterações sofridas ao longo desses 30 (trinta) anos, incluindo os erros e os grandes acertos. Atualmente, a adoção é considerada aos olhos do Estatuto como medida excepcional, sendo priorizada a manutenção das crianças e adolescentes no âmbito da família natural biológica, priorização esta bastante frisada ao longo da lei, mais especificamente repetida por 11 (onze) vezes ${ }^{33}$ ao longo do texto, de forma a dar preferência à família natural ou extensa.

Dito isto, faz-se necessário a análise dessas classificações das famílias, a fim de que seja possível aprofundar o estudo no instituto da adoção. Sendo assim, no primeiro artigo a tratar especificamente do tema artigo 39 do ECA - , surge o conceito de família natural que é definido pelo artigo 25 da mesma lei como: "a comunidade formada pelos pais ou qualquer deles e seus descendentes".

Prosseguindo, no parágrafo único do mesmo artigo supracitado, encontra-se a definição do segundo tipo de família aqui abordado, o da família extensa ou ampliada, sendo esta "aquela que se estende para além da unidade pais e filhos ou da unidade do casal, formada por parentes 
próximos com os quais a criança ou adolescente convive e mantém vínculos de afinidade e afetividade". Diante deste conceito, é importante ressaltar a última parte da definição, não bastando apenas que a pessoa seja parente da criança, mas faz-se essencial que mantenha com ela algum vínculo, convivência e laços de afetividade.

Ocorre que, a classificação de família se modificou ao longo dos anos diante de diversos entendimentos doutrinários e jurisprudenciais, de forma que hoje não mais se encontra abrangida apenas pelo conceito biológico, mas principalmente pelo socioafetivo, a fim de dar mais atenção aos laços emocionais e psicológicos criados entre os integrantes das famílias. Neste sentido, passa a ser extremamente questionável o conceito de família extensa que se restringe a compreender o termo "parentes" como àqueles ligados somente pelo laço biológicos e, consequentemente, excluem desse contexto possíveis padrastos, madrastas, padrinhos e madrinhas, por exemplo, que podem vir a se encaixar mais adequadamente na segunda parte do artigo que trata sobre afetividade.

Independente das discussões acerca de quem seria mais adequado para ocupar a posição da família extensa, no momento em que a criança se encontra afastada desse núcleo familiar natural e passa a ser cuidada pela família ampliada, esses novos responsáveis serão resguardados principalmente pelos institutos da guarda ou da tutela, isto porque, na maioria das vezes, eles (irmãos, avós, tutor e curador, por exemplo) serão os parentes mais próximos da criança que são proibidos de adotar, senão vejamos:

Art. 42. Podem adotar os maiores de 18 (dezoito) anos, independentemente do estado civil.

\section{$\S 1^{\circ} \underline{\text { Não }}$ podem adotar os ascendentes e os irmãos do adotando.}

Art. 44. Enquanto não der conta de sua administração e saldar o seu alcance, $\underline{\text { não }}$ pode o tutor ou o curador adotar o pupilo ou o curatelado. (grifo nosso).

No entanto, esses casos acabam gerando uma situação jurídica precária, dado que apesar de a guarda até gerar um vínculo de dependentes, 
inclusive para fins previdenciários (artigo $33, \S 3^{\circ}$ ), essas crianças e adolescentes não necessariamente desfrutam dos direitos sucessórios, permanecendo menos resguardados do que na adoção.

Apesar de toda regra possuir sua exceção, garante a jurista Maria Berenice Dias ${ }^{34}$, que em única e excepcional hipótese o Superior Tribunal de Justiça admitiu a adoção pelos avós, visto que os mesmos haviam adotado uma menina de apenas oito anos de idade e que estava grávida, conforme demonstra o julgado a seguir:

ESTATUTO DA CRIANÇA E DO ADOLESCENTE. RECURSO ESPECIAL. AÇÃO DE ADOÇÃO C/C DESTITUIÇÃO DO PODER FAMILIAR MOVIDA PELOS ASCENDENTES QUE JÁ EXERCIAM A PATERNIDADE SOCIOAFETIVA. SENTENÇA E ACÓRDÃO ESTADUAL PELA PROCEDÊNCIA DO PEDIDO. MÃE BIOLÓGICA ADOTADA AOS OITO ANOS DE IDADE GRÁVIDA DO ADOTANDO. ALEGAÇÃO DE NEGATIVA DE VIGÊNCIA AO ART. 535 DO CPC. AUSÊNCIA DE OMISSÃO, OBSCURIDADE OU CONTRADIÇÃO NO ACÓRDÃO RECORRIDO. SUPOSTA VIOLAÇÃO DOS ARTS. 39, § $1^{\circ}$, $41,42, \S \S 1^{\circ} \mathrm{E} 43$, TODOS DA LEI N. ${ }^{\circ} 8.069 / 90$, BEM COMO DO ART. 267, VI, DO CÓDIGO DE PROCESSO CIVIL. INEXISTÊNCIA. DISCUSSÃO CENTRADA NA VEDAÇÃO CONSTANTE DO ART. 42, § $1^{\circ}$, DO ECA. COMANDO QUE NẪO MERECE APLICAÇÃO POR DESCUIDAR DA REALIDADE FÁTICA DOS AUTOS. PREVALÊNCIA DOS PRINCÍPIOS DA PROTEÇÃO INTEGRAL E DA GARANTIA DO MELHOR INTERESSE DO MENOR. ART. $6^{\circ}$ DO ECA. INCIDÊNCIA. INTERPRETAÇÃO DA NORMA FEITA PELO JUIZ NO CASO CONCRETO. POSSIBILIDADE. ADOÇÃO MANTIDA. RECURSO IMPROVIDO. 1. Ausentes os vícios do art. 535, do CPC, rejeitam-se os embargos de declaração. 2. As estruturas familiares estão em constante mutação e para se lidar com elas não bastam somente as leis. É necessário buscar subsídios em diversas áreas, levando-se em conta aspectos individuais de cada situação e os direitos de $3^{\text {a }}$ Geração. 3. Pais que adotaram uma criança de oito anos de idade, já grávida, em razão de abuso sexual sofrido e, por sua tenríssima idade de mãe, passaram a exercer a paternidade socioafetiva de fato do filho dela, nascido quando contava apenas 9 anos de idade. 4. A vedacão da adocão de descendente por ascendente, prevista no art. $42, \S 1^{\circ}$, do ECA, visou evitar que o instituto fosse indevidamente utilizado com intuitos meramente patrimoniais ou assistenciais, bem como buscou proteger o adotando em relação a eventual "confusão mental e patrimonial" decorrente da "transformacão" dos avós em pais. 5. Realidade diversa do quadro dos autos, porque os avós sempre exerceram e ainda exercem a função de pais do menor, caracterizando típica filiação socioafetiva. 6. Observância do art. $6^{\circ}$ do ECA: na interpretação desta Lei levar-se-ão em conta os fins sociais a que ela se dirige, as exigências do bem comum, os direitos e deveres individuais e coletivos, e a condição peculiar da criança e do adolescente como pessoas

\footnotetext{
${ }^{34}$ DIAS, Maria Berenice. Op. cit., p. 68
} 
em desenvolvimento. 7. Recurso especial não provido. (Superior Tribunal de Justiça, REsp 1448969 SC 2014/0086446-1, Terceira Turma, Relator: Ministro MOURA RIBEIRO, Data de Julgamento: 21/10/2014, Data de Publicação: DJe 03/11/2014) (grifo nosso)

Ocorre que, nem todas as crianças que por algum motivo se afastaram de sua família natural podem ser recebidas por famílias extensas, de forma que em certos casos a solução entendida pelo legislador como mais adequada é a colocação desses menores em famílias substitutas, que para uma melhor compreensão pode ser definida como um gênero de família que abrange três espécies: a guarda, a tutela e a adoção, conforme estabelece o artigo 28 do ECA:

Art. 28. A colocação em família substituta far-se-á mediante guarda, tutela ou adocão, independentemente da situação jurídica da criança ou adolescente, nos termos desta Lei. (grifo nosso)

A fim de que ocorra a colocação do menor em família substitua, conforme determinado pelo Estatuto, deve existir a participação obrigatória dos maiores de 12 anos e, sempre que for possível, dos menores de 12 anos, respeitando seus respectivos estágios de desenvolvimento e grau de compreensão sobre as implicações da medida, devendo garantir que os mesmos sejam ouvidos previamente por equipe técnica interprofissional (§ $1^{\circ}$ do artigo 28$)$.

Além disso, deve ser considerado o grau de parentesco das figuras que representam essa família substituta, ressaltando que não apenas o vínculo biológico predomina neste tipo de relação, mas inclusive a segunda parte do $\S 2^{\circ}$ do artigo 28 ressalta a importância em considerar a afinidade e afetividade nessa conexão, ampliando esse conceito para as relações socioafetivas sempre com o condão de minimizar as consequências ruins e preservar o menor.

No que se refere aos grupos de irmãos, esses também recebem uma atenção especial e priorização pela colocação de todos na mesma família substituta, a fim de resguardar o núcleo natural daqueles menores, conforme expõe o $\S 4^{\circ}$ do artigo supracitado. 
Neste sentido, independentemente da espécie dentro do gênero família substituta que a criança ou o adolescente vier a ser incluído, sempre serão respeitadas as regras até então dispostas, ressaltando que todos os menores sempre deverão ser preparados pela equipe interprofissional e assim garantir todo o apoio técnico necessário (artigo $28, \S 5^{\circ}$ do ECA).

Iniciando o tratamento dessas espécies do gênero família substituta encontra-se a guarda que se trata de um instituto de responsabilização para com a vida do menor de idade, na qual obriga o guardião a prestação de assistência material, moral e educacional, conferindo ao detentor desse múnus o direito de opor-se a terceiros, inclusive aos pais da criança ou do adolescente (artigo 33 do ECA). Cada vez mais o termo guarda se afasta da idéia inicial de posse, de visualizar o filho como um objeto, e se aproxima de uma idéia mais humanizada de responsabilização sobre os direitos e deveres para com a formação dos pequenos.

Já como a segunda espécie, surge a tutela que consiste no encargo conferido a alguém para que dirija atos do cotidiano e administre os bens dos menores de idade ${ }^{35}$, sendo necessário destacar que para o surgimento do instituto se pressupõe a prévia decretação da perda ou suspensão do poder familiar e implica necessariamente no dever de guarda (artigo 36 do ECA).

Neste hiato, seria lógico a abordagem da terceira espécie de família substituta, a adoção, no entanto, antes de começar o aprofundamento nesse tema, faz-se necessária a compreensão de mais três formas de acolhimento dos menores brasileiros e que por alguns ainda se tratam de modalidades desconhecidas. Estas outras três modalidades se tratam de caminhos com uma idéia um pouco mais reduzida de estabilidade e durabilidade, sendo elas as famílias acolhedoras, o apadrinhamento e da institucionalização.

Em primeiro lugar, cabe definir que o núcleo chamado de família acolhedora advém do Programa de Famílias Acolhedoras, caracterizado 
como um serviço conduzido pelo Estado que organiza o acolhimento de crianças e adolescentes afastados da família de origem, na residência das famílias voluntárias mediante medida protetiva, oferecendo proteção integral aos menores até que seja possível a reintegração ao núcleo familiar natural.

Tal programa possui um sistema próprio de funcionamento que consiste na mobilização, cadastramento, seleção, capacitação, acompanhamento e supervisão dessas famílias acolhedoras por equipe multidisciplinar; bem como uma continuidade no acompanhamento das famílias de origem dessas crianças e adolescentes, visto que o objetivo final do programa é que elas possam ser recebidas de volta no seio da família de origem de forma segura.

Portanto, essa medida em nada se confunde com as anteriores, visto se tratar de um acolhimento provisório na qual uma família estranha ao menor passa a ter a guarda provisória do mesmo até que seja viabilizada uma solução de caráter permanente para a criança ou adolescente que se perfaz pela reintegração na família natural, na família extensa ou por meio da adoção.

A família acolhedora passa a ser, portanto, uma alternativa ao abrigo e institucionalização, de forma a proporcionar um cuidado individualizado em um momento de instabilidade do menor, com a idéia de preservar idealmente o vínculo da criança com a família de origem e sempre seguindo as regras previstas no Estatuto nos artigos 92,93 e 101, $\S 1^{036}$ :

36 Plano nacional de proteção e defesa do direito de crianças e adolescentes à convivência familiar e comunitária. Disponível em <https://www.mds.gov.br/webarquivos/publicacao/assistencia_social/Cadernos/Plano_Defesa_Cri ancasAdolescentes\%20.pdf>. Acesso em 29 set. 2019. 
Art. 101. Verificada qualquer das hipóteses previstas no art. 98, a autoridade competente poderá determinar, dentre outras, as seguintes medidas:

$\S 1^{\circ} \underline{O}$ acolhimento institucional e o acolhimento familiar são medidas provisórias e excepcionais, utilizáveis como forma de transicão para reintegração familiar ou, não sendo esta possível, para colocação em família substituta, não implicando privacão de liberdade. (grifo nosso)

Cabe ressaltar que no texto original do plano nacional de proteção e defesa do direito de crianças e adolescentes à convivência familiar e comunitária, esta modalidade de acolhimento surgiu em meio a um cenário de esquecimento das crianças e adolescentes em abrigos, na qual o sistema público não vinha tratando da solução desses conflitos familiares com a devida prioridade que o Estatuto da Criança e do Adolescente preconiza.

O segundo caminho para amenizar o acolhimento se trata de outro programa ainda não muito conhecido, o do apadrinhamento, um programa organizado por órgãos públicos ou entidades da sociedade civil, que consiste em voluntários previamente selecionados pelas equipes técnicas das Varas de Infância especializadas que contribuem para com o desenvolvimento das crianças mais velhas e adolescentes já acolhidos e que se encontrem em um limbo visto que, em geral, não existem condições de serem reintegrados à família de origem ou extensa, também não fazem parte do perfil das crianças pequenas procuradas por brasileiros para adoção, em instituições e, ao completarem 18 anos, acabam sendo lançados ao mundo de forma totalmente desassistida.

Esse programa de apadrinhamento teve sua origem baseada na Lei Portuguesa $n^{\circ} 103$, de 11 de setembro de $2009^{37}$, na qual foi aprovado o regime jurídico de apadrinhamento civil, cuja definição está estabelecida no artigo $2^{\circ}$ da própria lei:

37 Lei Portuguesa $\mathrm{n}^{\circ} 103$, de 11 de setembro de 2009. Disponível em <http://www.pgdlisboa.pt/leis/lei_mostra_articulado.php?nid=1128\&tabela=leis\&so_miolo=>. Acesso em 9 out. 2019. 
“O apadrinhamento civil é uma relação jurídica, tendencialmente de carácter permanente, entre uma criança ou jovem e uma pessoa singular ou uma família que exerça os poderes e deveres próprios dos pais e que com ele estabeleçam vínculos afectivos que permitam o seu bem-estar e desenvolvimento, constituída por homologação ou decisão judicial e sujeita a registo civil."

O programa brasileiro consiste no estabelecimento de vínculo entre os padrinhos/madrinhas e as respectivas crianças e adolescentes por meio de laços afetivos duradouros ou por meio de contribuição financeira. Este modelo se difere das famílias acolhedoras, visto que não se trata do estabelecimento de um vínculo diário da criança com o padrinho, mas sim por meio de visitações ao abrigo, da saída dos menores para as residências dos padrinhos aos finais de semana, férias e feriados, por exemplo.

Sendo assim, as crianças e adolescentes permanecem residindo no abrigo/instituição, mas passam a ser liberados para realizar determinadas atividades com o padrinho, conforme disposto no artigo 19-B do ECA:

Art. 19-B. A criança e o adolescente em programa de acolhimento institucional ou familiar poderão participar de programa de apadrinhamento.

$\S 1^{\circ} \mathrm{O}$ apadrinhamento consiste em estabelecer e proporcionar à criança e ao adolescente vínculos externos à instituição para fins de convivência familiar e comunitária e colaboração com o seu desenvolvimento nos aspectos social, moral, físico, cognitivo, educacional e financeiro

Além disso, o programa de apadrinhamento pode ser desempenhado por pessoa jurídica $\left(\S 3^{\circ}\right.$ do art. 19-B) e o perfil do menor a ser apadrinhado será definido conforme o programa de cada Vara da Infância, obedecendo a prioridade para crianças ou adolescentes com remota possibilidade de reinserção familiar ou colocação em família adotiva, conforme dito anteriormente e estabelecido no $\S 4^{\circ}$ do artigo supracitado.

A fim de participar tanto do programa de famílias acolhedoras como o de apadrinhamento, os voluntários não podem ser candidatos à adoção, isto porque idealmente eles seriam apenas um ponto de apoio para essas crianças e adolescentes que enfrentam momentos difíceis e, posteriormente, seriam reintegrados às suas famílias de origem: 
$\S 2^{\circ}$ Podem ser padrinhos ou madrinhas pessoas maiores de 18 (dezoito) anos não inscritas nos cadastros de adoção, desde que cumpram os requisitos exigidos pelo programa de apadrinhamento de que fazem parte.

A $1^{\text {a }}$ Vara da Infância, Juventude e Idoso da Comarca da Capital do Estado do Rio de Janeiro criou o projeto "Afeto que Afeta" ${ }^{38}$ que visa permitir que crianças, a partir de 8 anos, e adolescentes, em medida de proteção de abrigamento, vivam experiências e referências afetivas, tanto familiares quanto comunitárias. Assim, a principal proposta do projeto é sensibilizar a sociedade para o abandono de crianças e adolescentes que se encontram privados de uma relação afetiva junto a sua família, atravessando sua infância e, muitas das vezes, adolescência, no interior das instituições de acolhimento.

O projeto tenta trazer à vida dos "afilhados" a contribuição necessária para a conquista da autonomia social e na potencialização da auto-estima das crianças e adolescentes atendidas, por meio de visitações no abrigo, saídas às casas dos padrinhos nos finais de semana, feriados e férias.

Além disso, destaca o texto original do projeto a possibilidade que o programa de apadrinhamento pode trazer ao processo de adoção, senão vejamos:

"a presença de padrinhos pode auxiliar no processo de adoção, pois, muitas das vezes, as experiências familiares prévias produzem resistências nas crianças e adolescentes, que não acreditam que as vivências em família possam ser positivas, dificultando a aproximação de interessados em adotar. Construir uma história de relação e referência a uma pessoa fora do ambiente institucional, como um padrinho e/ou uma madrinha, vem sendo demonstrado, ao longo das experiências análogas em outros estados do Brasil,

38 Projeto "Afeto que afeta" da $1^{\text {a }}$ Vara da Infância, da Juventude e do Idoso da Comarca da Capital do Estado do Rio de Janeiro. Disponível em <http://infanciaejuventude.tjrj.jus.br/boaspraticas/projetos/1vara-capital/apafetivo.html>. Acesso em 09 out. 2019. 
ser uma experiência e convivência enriquecedora para ambos os lados, colocando em cheque os preconceitos sociais de etnia, faixa etária ou saúde que, sem dúvida, permeiam em nossa sociedade. A vinculação afetiva construída na constância estabelece relacionamentos estáveis e duradouros que virão a tornar-se referenciais familiares e sociais para suas vidas futuras e evitando, assim, os sentimentos de vazio e solidão, muito comuns nos jovens em situação de abandono e que são obrigados a depararem-se com a maioridade."

Ademais, a atual $3^{\text {a }}$ Vara da Infância, da Juventude e do Idoso da Comarca da Capital do Estado do Rio de Janeiro, também possui o Projeto Apadrinhar $^{39}$ que foi implementado no ano de 2009, com base no Plano Nacional de Convivência Familiar e Comunitária, aprovado em novembro de 2006 pela CONANDA (Conselho Nacional dos Direitos da Criança e do Adolescente) - texto esse que tem como objetivo a orientação e elaboração de políticas públicas que visam a efetivação dos direitos das crianças e adolescentes ao convívio familiar e comunitário.

O supracitado projeto tem sua gama de padrinhos aumentada, de forma que existe o apadrinhamento material - basicamente relacionado à assunção de despesas da criança -, o apadrinhamento afetivo - no qual o foco é a preocupação com o bem-estar do menor-, o apadrinhamento familiar - quando as famílias naturais são auxiliadas no intuito de prestar assistência aos filhos por falta de recursos econômicos -, o padrinho/madrinha prestador de serviços - presta serviços gratuitos ao abrigo de acordo com sua área de formação e interesse -, e, por fim, o apadrinhamento de pessoa jurídica - quando uma pessoa jurídica apadrinha determinada entidade de acolhimento institucional, dando apoio material ou financeiro.

No entanto, diante de uma realidade brasileira na qual a manutenção dessas crianças e, principalmente, desses adolescentes, se dá por muitos anos em instituições sem que seja possível a reinserção na sua família natural ou em família extensa - que é buscada incansavelmente e que por

39 Projeto Apadrinhar da $3^{\text {a }}$ Vara da Infância, da Juventude e do Idoso da Comarca da Capital do Estado do Rio de Janeiro. Disponível em $<$ http://infanciaejuventude.tjrj.jus.br/boaspraticas/docs/projeto-apadrinhar.pdf>. Acesso em 9 out 2019. 
vezes o menor não possui qualquer vínculo -, essas modalidades de acolhimento por seu caráter provisório acabam por se transformar em uma faca de dois gumes. Isto porque, apesar de trazer um acalanto para o coração dos pequenos institucionalizados ou a beira da institucionalização, por ser uma solução temporária, resulta na criação de um vínculo de afeto que poderia vir a ser posteriormente rompido, trazendo as nossas crianças mais uma sensação de perda.

Neste sentido, a fim de exaltar o trabalho das benéficas experiências obtidas com o programa de apadrinhamento, bem como o das famílias substitutas, como forma de respeitar justamente esse laço afetivo construído entre todos os envolvidos e atendendo, primordialmente, ao melhor interesse da criança ou do adolescente que no XII Congresso Brasileiro de Direitos das Famílias e Sucessões realizado em outubro de 2019, foi aprovado o Enunciado $\mathrm{n}^{\circ} 36$ que veio justamente para evitar que mais uma vez um vínculo seja rompido: "as famílias acolhedoras e os padrinhos afetivos têm preferência para adoção quando reconhecida a constituição do vínculo de socioafetividade".

Por fim, o terceiro e último caminho abordado neste capítulo é aquele que, infelizmente, se fez mais comum e conhecido em nossa sociedade, o da colocação dos menores em instituições de acolhimento, medida esta de proteção aplicada pelo juízo da Vara de Infância sempre que houver risco aos menores (art. 101, VII do ECA). Este caminho deve ser tratado como alternativa provisória e deveria respeitar o prazo máximo de 18 (dezoito) meses previsto no ECA. Além disso, todo menor deve ter sua situação reavaliada, no máximo, a cada 3 (três) meses, conforme estabelecido no parágrafo $2^{\circ}$ e $3^{\circ}$ do artigo 19 do ECA.

As regras supracitadas existem em razão de uma questão lógica: as crianças e os adolescentes não possuem no abrigo o tratamento adequado que uma família salutar - independente do tipo e da sua constituição - 
conseguiria prover àquele menor sendo uma referência emocional saudáveis ao desenvolvimento de qualquer criança e adolescente.

Ora, o desenvolvimento de um apego saudável essencial a toda criança e adolescentes para a formação da sua personalidade se encontra muito precário em um cenário de internação social e, além disso, conforme alerta Ana Lúcia Simões ${ }^{40}$ se o apego não é tão sólido, a probabilidade da criança vir a desenvolver um comportamento antissocial na adolescência e na vida adulta aumenta significantemente, além do que ao ficarem muito tempo institucionalizados esses menores brasileiros ficam mais propensos a desenvolver padrões agressivos, de isolamento, insegurança, rejeição, baixa autoestima, ansiedade e até depressão.

Ocorre que, se por um lado o Estado busca por meio das políticas de institucionalização de acolhimento diminuir os efeitos da violência intrafamiliar que afeta esses pequenos, por outro a permanência em "abrigos" também produz grande stress diante da ausência de vínculos emocionais e, consequentemente, da formação de indivíduos apáticos "fillhos do Estado, órfãos de "pais vivos"”, sem referências familiares e sem referências afetivas.

Obviamente, a própria sistemática de funcionamento da maioria das unidades de acolhimento nas quais os cuidadores laboram através de escalas e plantões, a divisão por sexos propicia separação de grupos de irmãos e a transferência institucional após a chegada a idade limite, ocasionam uma despersonalização no atendimento dos menores que estão abrigados.

Destarte, por todo o exposto, questionável se torna a primeira característica aqui exposta da adoção: a excepcionalidade, visto que seu tratamento como última medida favorece, consequentemente, a manutenção dos menores em abrigos que nem minimamente atendem a função de um núcleo familiar, prolongando desnecessariamente uma espera de uma

\footnotetext{
${ }^{40}$ DIAS, Maria Berenice. Op. cit., p. 65.
} 
família extensa que a criança não possui o mínimo vínculo ou acolher essas crianças que já possuem um vínculo rompido em núcleos temporários dos quais elas se apegam e logo em seguida também são afastadas, ocasionando por duas vezes um momento de desestabilização que pode ser irreparável.

Outrossim, cabe afirmar que em momento algum é questionado pelo presente trabalho os benefícios decorrentes da manutenção dos filhos no núcleo familiar de origem, no entanto, estas famílias naturais precisam (i) ser salutares ou caso negativo elas precisam (ii) se adaptar em tempo hábil para transformar o ambiente em um local propício para criação dos pequenos brasileiros, isto porque a infância é uma época crucial para o desenvolvimento de qualquer cidadão, mas ao mesmo tempo se trata de um tempo finito e que não pode ficar à mercê das mudanças vagarosas e, por vezes, impossíveis. 


\section{A ADOÇÃO NA ATUALIDADE}

A adoção, conforme inicialmente abordado nesse estudo, pode ser definida como um "ato jurídico pelo qual uma pessoa recebe a outra como filho, independentemente de existir entre elas qualquer relação de parentesco consangüíneo ou afim "41, tratando-se atualmente de uma das modalidades de família substituta (artigo 28 do ECA) na qual são colocadas as crianças e adolescentes que por algum motivo foram separados do núcleo da família natural.

Essa modalidade de família substituta estabelece a constituição do parentesco civil entre o adotante e o adotado, um parentesco eletivo ${ }^{42}$ por decorrer de um ato de vontade e que, no entendimento do Ministro Luiz Edson Fachin ${ }^{43}$, trata-se de uma modalidade de filiação construída no amor. A adoção, portanto, não se trata de um ato de caridade, afinal ninguém decide ser pai ou mãe porque é caridoso, mas sim porque querem constituir uma família, cabendo ressaltar que não se trata de uma modalidade que busca uma criança para uma família - visão antiga que se buscava ajudar aquelas famílias consideradas inférteis, como se fosse uma paternidade de segundo grau - mas sim da busca de uma família para uma criança, estando esta última no núcleo da adoção amparada pela doutrina da proteção integral.

Desta forma, constituem-se as famílias decorrentes do afeto nas quais o princípio da dignidade da pessoa humana as norteia desde as suas formações até o reconhecimento das mesmas. Sem sombra de dúvidas, a adoção passa a ser sempre uma via de mão dupla, na qual os pais e filhos se adotam mutuamente e não apenas os pais aos filhos, conforme entende 
Lúcia Maria de Paula Freitas ${ }^{44}$. Sendo assim, dado que adoção subjetivamente se entende como ato de afeto recíproco, todos os filhos independentemente da forma como chegaram àquela família precisam ser adotas.

No que se refere ao caráter jurídico, o doutrinador Caio Mário da Silva Pereira aponta que todos os autores reconhecem à adoção o caráter de uma fictio iuris ${ }^{45}$, ou seja, uma ficção jurídica. Entretanto, tal definição ainda é tema de divergência na doutrina, de forma que por vezes foi ou permanece sendo vista como instituição, como ato jurídico, como ato de natureza híbrida, como contrato e como ato complexo ${ }^{46}$.

Inicialmente, na doutrina civilista do século XIX, a adoção era ligada a uma noção de contrato e podia até ser realizada em Cartório de Ofício de Notas conforme são realizados os contratos/escrituras privadas, mas com o decorrer do tempo, essa prática não mais vigorava dado que se tornou um ato jurídico dotado de solenidades e regulado como um ato de interesse público e privativo do Estado, na qual não mais se admitia a liberdade na estipulação dos seus efeitos.

Neste sentido, a doutrinadora Maria Helena Diniz também considera a adoção como um ato jurídico solene, por meio do qual uma ficção legal possibilita a constituição de um laço de parentesco entre o adotante e o $\operatorname{adotado}^{47}$.

A corrente que defende a adoção como ato jurídico complexo entende que existem dois momentos: o primeiro de natureza negocial no qual haverá a manifestação de vontade das partes interessadas à adoção e, posteriormente, num segundo momento ocorrerá a intervenção do Estado

44 FREITAS, Lúcia Maria de Paula. Adoção - Quem de nós quer um filho? Revista Brasileira de Direito de Família. Porto Alegre, n. 10, p. 146-155, jul/set., 2001, p.153.

45 PEREIRA, Caio Mário da Silva. Op. cit., p. 470.

46 MACIEL, Kátia Regina Ferreira Lobo Andrade. Curso de Direito da Criança e do Adolescente: aspectos teóricos e práticos. $8^{\mathrm{a}} \mathrm{ed}$ rev. e atual. São Paulo: Saraiva, 2015. p 291.

47 DINIZ, Maria Helena. Curso de direito civil brasileiro. Vol 5: direito de família. $21^{\mathrm{a}}$ ed.. São Paulo: Saraiva, 2006. p. 498 e 499. 
que determinará a conveniência ou não da adoção. Esse primeiro momento se dá na fase postulatória e o segundo se dá na fase instrutória do processo judicial de adoção ${ }^{48}$.

Independentemente da definição jurídica, é um fato incontestável que a adoção incumbe aos novos pais e mães o dever de garantir, em observância ao artigo 22 do ECA, o sustento, a guarda e a educação dos filhos e se responsabilizam pelos menores. Além disso, a adoção se trata de um ato personalíssimo que não pode ser feito por procuração (artigo 39, § $2^{\circ}$ do ECA); irrevogável a medida que impossibilita a retomada do poder familiar pela família biológica (artigo 39, $\S 1^{\circ}$ do ECA); imprescritível, de forma que o falecimento dos adotantes não implica na restituição do poder familiar aos pais biológicos (artigo 49 do ECA); dotado de plenitude, visto que os adotandos adquirem as mesmas condições de filhos biológicos (artigo 20 do ECA) e, por fim, é imprescritível, vale dizer, não decai com o fato do pai ou da mãe deixar de exercê-lo. ${ }^{49}$

O vínculo da adoção se constitui apenas por sentença judicial transitada em julgado proferida pelo juiz da Justiça da Infância e do Adolescente em obediência as regras do ECA (artigo 47 do referido diploma), nos casos de adoção de menores, ou pelos juízos de Família regidos pelo Código Civil no caso de adoção de maiores de 18 anos.

Portanto, a adoção de crianças e adolescentes se encontra regulamentada pelo Estatuto da Criança e do Adolescente que sofreu alterações em relação ao tema com o advento da Lei ${ }^{\circ}$ 12.010/2009 responsável por realizar alterações significativas em prol da garantia do direito à convivência familiar, priorizando a família natural e estabelecendo a colocação em família substituta como medida excepcional. À época e com o passar dos anos, a Lei 12.010 sofreu inúmeras elogios, mas também 
muitas críticas por entenderem que a aplicação de certas normas seria impraticável e iriam piorar o sistema que já não era tão bom.

Além da referida lei, outras modificações ocorreram em razão da Lei $\mathrm{n}^{\circ}$ 13.509/2017 responsável por, principalmente, agilizar o tempo e os trâmites dos procedimentos que envolvem a adoção, podendo ser destacadas dentre suas principais mudanças a redução do período de acolhimento institucional (artigo 19); a fixação de regras sobre a entrega da criança à adoção, estabelecendo um tempo máximo para busca de família extensa (artigo 19-A, § $3^{\circ}$ ); a melhoria na regulamentação do programa de apadrinhamento (artigo 19-B); o estabelecimento do prazo máximo de 90 (noventa) dias para o estágio de convivência (artigo 46); o estabelecimento do prazo máximo para a conclusão do processo de adoção e procedimento de habilitação em 120 (cento e vinte) dias e, por derradeiro, o estabelecimento da contagem de prazos em dias corridos, vedado o prazo em dobro para a Fazenda Pública e o Ministério Público.

\subsection{TIPOS DE ADOÇÃO}

A adoção dos menores de idade pode ocorrer de diferentes formas, dentre elas via: (i) adoção individual, (ii) adoção conjunta, (iii) adoção anaparental, (iv) adoção unilateral, (v) adoção intuitu personae, (vi) adoção à brasileira, (vii) adoção homoparental e (viii) adoção póstuma.

Primeiramente, a (i) adoção individual se dá nos casos em que um único indivíduo maior de 18 anos (requisito presente no artigo 42 do $\mathrm{ECA}^{50}$, independentemente do seu estado civil (podendo ser solteiro, casado, viúvo, companheiros convivendo em união estável e divorciados), se candidata à adoção.

Neste caso de adoção, bem como em todos os outros faz-se necessário que além de maior de idade o adotante tenha uma diferença mínima de 16 (dezesseis) anos de idade em relação ao adotado, conforme 
estabelece o $\S 3^{\circ}$ do artigo supracitado. Entretanto, a fim de resguardar o melhor interesse da criança, o Supremo Tribunal Federal concedeu a adoção cuja diferença entre o adotando e o adotado - este já maior de idade - era inferior a 16 (dezesseis anos), demonstrando que a regra deve prevalecer, mas não necessariamente de forma absoluta, variando de acordo com o caso em concreto, conforme pode ser observado em recentíssimo julgado:

RECURSO ESPECIAL. DIREITO DE FAMÍlIA. PROCESSUAL CIVIL E CIVIL. ADOÇÃO. MAIOR. ART. 42, § $3^{\circ}$, DO ECA (LEI No 8.069/1990). IDADE. DIFERENÇA MÍNIMA. FLEXIBILIZAÇÃO. POSSIBILIDADE. SOCIOAFETIVIDADE. INSTRUÇÃO PROBATÓRIA. IMPRESCINDIBILIDADE. 1. Recurso especial interposto contra acórdão publicado na vigência do Código de Processo Civil de 2015 (Enunciados Administrativos $\mathrm{n}^{\circ} \mathrm{s} 2$ e 3/STJ). 2. A diferença etária mínima de 16 (dezesseis) anos entre adotante e adotado é requisito legal para a adoção (art. 42 , $\S 3^{\circ}$, do ECA), parâmetro legal que pode ser flexibilizado à luz do princípio da socioafetividade. 3. O reconhecimento de relação filial por meio da adoção pressupõe a maturidade emocional para a assunção do poder familiar, a ser avaliada no caso concreto. 4. Recurso especial provido. (STJ, Recurso Especial $\mathrm{n}^{\circ}$ 1.785.754 - RS (2018/0322826-2), Terceira Turma, Relator Ministro Ricardo Villas Bôas Cueva, Data do Julgamento: 08/10/2019, Data de Publicação DJe $10 / 10 / 2019)$

$\mathrm{Na}$ sequência, a (ii) adoção conjunta possui as mesmas características da adoção individual, diferindo apenas na quantidade de adotantes, devendo nesta modalidade ocorrer por mais de um pretendente e que, de acordo com o ECA, é indispensável que os adotantes sejam casados civilmente ou mantenham união estável, comprovada a estabilidade da família, conforme $\S 2^{\circ}$ do artigo 42 .

Nesse modelo de adoção, caso o casal habilitado venha a se divorciar, se separar judicialmente ou dissolver a união estável, os mesmos podem permanecer adotando conjuntamente desde que o estágio de convivência já tenha se iniciado e que seja comprovado a existência de vínculos de afinidade e afetividade, visto ser um fato passível de ocorrer no cotidiano de qualquer casal parental, mas é essencial que os pais acordem sobre a guarda e o regime de convivência (artigo $42, \S 4^{\circ}$ do ECA). 
Além disso, a doutrinadora Maria Berenice Dias traz o conceito de (iii) adoção anaparental ${ }^{51}$ que deriva da família anaparental, aquela constituída sem a presença de um ascendente e o vínculo que une os seus integrantes não é sexual, sendo o exemplo mais comum deste tipo de família os irmãos que convivem sem a presença dos pais. A fim de elucidar este tipo de família e adoção, cabe ressaltar o seguinte julgado do Supremo Tribunal Federal:

RECURSO ESPECIAL. ADOÇÃO PÓSTUMA. VALIDADE. ADOÇÃO CONJUNTA. PRESSUPOSTOS. FAMÍLIA ANAPARENTAL. POSSIBILIDADE. Ação anulatória de adoção post mortem, ajuizada pela União, que tempor escopo principal sustar o pagamento de benefícios previdenciários ao adotado - maior interdito -, na qual aponta a inviabilidade da adoção post mortem sem a demonstração cabal de que o de cujus desejava adotar e, também, a impossibilidade de ser deferido pedido de adoção conjunta a dois irmãos.A redação do art. $42, \S 5^{\circ}$, da Lei $8.069 / 90$ - ECA -, renumerado como $\S 6^{\circ}$ pela Lei 12.010/2009, que é um dos dispositivos de lei tidos como violados no recurso especial, alberga a possibilidade de se ocorrer a adoção póstuma na hipótese de óbito do adotante, no curso do procedimento de adoção, e a constatação de que este manifestou,em vida, de forma inequívoca, seu desejo de adotar. Para as adoções post mortem, vigem, como comprovação da inequívoca vontade do de cujus em adotar, as mesmas regras que comprovam afiliação socioafetiva: o tratamento do menor como se filho fosse e o conhecimento público dessa condição.O art. $\underline{42}, \S 2^{\circ}$, do ECA, que trata da adoção conjunta, buscou assegurar ao adotando a inserção em um núcleo familiar no qual pudesse desenvolver relações de afeto, aprender e apreender valores sociais, receber e dar amparo nas horas de dificuldades, entre outras necessidades materiais e imateriais supridas pela família que, nas suas diversas acepções, ainda constitui a base de nossa sociedade. A existência de núcleo familiar estável e a consequente rede de proteção social que podem gerar para o adotando, são os fins colimados pela norma e, sob esse prisma, 0 conceito de núcleo familiar estável não pode ficar restrito às fórmulas clássicas de família, mas pode, e deve, ser ampliado para abarcar uma nocão plena de família, apreendida nas suas bases sociológicas. Restringindo a lei, porém, a adoção conjunta aos que, casados civilmente ou que mantenham união estável, comprovem estabilidade na família, incorre em manifesto descompasso com o fim perseguido pela própria norma, ficando teleologicamente órfã. Fato que ofende o senso comum e reclama atuacão do interprete para flexibilizá-la e adequá-la às transformacões sociais que dão vulto ao anacronismo do texto de lei. O primado da família sócio afetiva tem que romper os ainda existentes liames que atrelam o grupo familiar a uma diversidade de gênero e fins reprodutivos, não em um processo de extrusão, mas sim de evolução, onde as novas situações se acomodam ao lado de tantas outras, já existentes, como possibilidades de grupos familiares. 
O fim expressamente assentado pelo texto legal - colocação do adotando em família estável - foi plenamente cumprido, pois os irmãos, que viveram sob o mesmo teto, até o óbito de um deles, agiam como família que eram, tanto entre si, como para o então infante, e naquele grupo familiar o adotado se deparou com relações de afeto, construiu - nos limites de suas possibilidades seus valores sociais, teve amparo nas horas de necessidade físicas e emocionais,em suma, encontrou naqueles que o adotaram, a referência necessária para crescer, desenvolver-se e inserir-se no grupo social que hoje faz parte.Nessa senda, a chamada família anaparental - sem a presença de umas cendente -, quando constatado os vínculos subjetivos que remetem à família, merece o reconhecimento e igual status daqueles grupos familiares descritos no art. $42, \S 2$, do ECA.Recurso não provido. (Superior Tribunal de Justiça, REsp n ${ }^{\circ} 1217415$ RS 2010/0184476-0, Relatora Ministra Nancy Andrighi, Data de Julgamento em 19/06/2012, Terceira Turma, Data de Publicação no DJe em 28/06/2012), (grifo nosso).

No julgado supracitado, o Superior Tribunal de Justiça concedeu a adoção de uma pessoa maior de idade a dois irmãos, sob a fundamentação de que esse adotando (que era interditado) tinha sido criado como filho pelos dois, constituindo um núcleo de família estável e afetivo. Ocorre que, o deferimento de tal tipo de adoção - bem como todas as outras - deve levar em consideração, primordialmente, o melhor interesse da criança, de forma que se no caso em concreto a concessão desta modalidade traz mais benefícios do que malefícios para a criança ou adolescente, em momento algum deveria ser questionável o seu deferimento.

No entanto, infelizmente, este não é o entendimento de toda a doutrina, senão vejamos a opinião de Galdino Augusto Coelho Bordalho ${ }^{52}$ :

\footnotetext{
“A adoção por irmãos terá ainda maior dificuldade de ser aceita pela sociedade do que a de duas pessoas do mesmo sexo. Ao ver-se que uma criança tem em sua certidão o nome de duas pessoas que são irmãos, todos os preconceitos sociais serão ativados de uma única vez. Nossa sociedade, assim como as estrangeiras, não aceitam relações sexuais entre os irmãos, sendo isso, inclusive, uma vedação imposta pelas religiões.
}

Ora, faz-se essencial a proteção da criança sob qualquer circunstância, incluindo neste sentido o fato de evitar ao máximo que ela sofra qualquer tipo de exposição a qualquer situação vexatória/preconceituosa. No entanto, diante de um avanço social e doutrinário tão relevante na consideração da família como um instituto de

\footnotetext{
${ }^{52}$ MACIEL, Kátia Regina Ferreira Lobo Andrade. Op. cit. p 343.
} 
afetividade que não necessariamente se faz vinculado à conotação sexual e biológica, os profissionais do Direito deveriam dar mais atenção ao que faz bem às suas respectivas populações, sempre de forma cautelosa e muito bem questionada, e não permanecerem guiados levianamente por tradições religiosas que não mais refletem o posicionamento contemporâneo, pelo contrário, esse posicionamento por inúmeras vezes questionam e afastam de suas realidades esses regramentos eclesiásticos.

No que se refere à quarta modalidade, (iv) a adoção unilateral, esta se define como a modalidade na qual será alterado uma das linhas de parentesco, resultante de uma constituição familiar muito presente nos dias atuais, quando os casais parentais migram de um relacionamento para outro, por exemplo, construindo novas formações familiares.

Neste tipo de adoção o cônjuge ou o companheiro adota o filho do outro, quer essa criança tenha sido resultado de um relacionamento anterior ou advinda de adoção e, portanto, não exige o procedimento de cadastramento do adotante. Essa adoção se faz em três hipóteses: primeiramente, nos casos em que apenas constar tão somente o nome de um dos genitores no registro de nascimento, devendo haver o consentimento por parte daquele genitor registrado; nos casos em que conste o nome dos dois genitores no registro, hipótese esta em que deverá ocorrer a destituição do poder familiar daquele que perderá o vínculo com o menor; ou, por fim, no caso de adoção por cônjuge ou companheiro, quando um dos genitores do menor tiver falecido, havendo a necessidade apenas do consentimento do genitor sobrevivente.

A quinta modalidade de adoção é a (v) adoção intuitu personae, também conhecida como adoção direta, que causa polêmicas no Direito Brasileiro, consistindo basicamente na modalidade em que os pais biológicos interferem na escolha dos pais adotivos. Infelizmente, os pais biológicos que por meio da sua escolha visam zelar pelo bem-estar do seu filho, acabam sendo julgados de forma negativa como se tivessem cometido 
uma espécie de crime e não por terem tomado uma atitude resultante de falta de condições - econômicas, emocionais ou psicológicas - de cuidar de uma criança.

Esta atitude também pode derivar da falta de política de saúde pública (na qual as mulheres não tem direito de decidir sobre seu próprio corpo e, consequentemente, sobre o avanço de uma gravidez) ou até mesmo do fato desses pais nunca terem desejado desempenhar esse papel, ou seja, cabe a todos aceitar a realidade de que a maternidade e a paternidade não são romantizadas, idealizadas e esperadas por todos.

Neste sentido, diante da escolha madura e consciente do desejo de entregar do filho para adoção, nada mais justo que esses pais busquem aquilo que entendem ser melhor para criança e essa escolha deveria ser respeitada, afinal, se os pais tomam essa decisão é porque nenhum deles gostaria que o filho fosse colocado em um abrigo ou mesmo entregue para a família extensa, senão os mesmos já teriam realizado esta última opção diretamente.

No que se refere às normas regulamentadoras o enunciado $n^{\circ} 13$ do IBDFAM resguarda exatamente essa escolha dos pais biológicos: " $n a$ hipótese de adoção intuitu personae de criança e adolescente, os pais biológicos podem eleger os adotantes" ${ }^{\prime 53}$. Quanto ao ECA, em seu artigo 50, $\S 13^{\circ}$, a adoção intuitu personae é prevista em três hipóteses bem mais restritivas, sendo elas:

$\S 13$. Somente poderá ser deferida adoção em favor de candidato domiciliado no Brasil não cadastrado previamente nos termos desta Lei quando:

I - se tratar de pedido de adoção unilateral;

II - for formulada por parente com o qual a criança ou adolescente mantenha vínculos de afinidade e afetividade; 
III - oriundo o pedido de quem detém a tutela ou guarda legal de criança maior de 3 (três) anos ou adolescente, desde que o lapso de tempo de convivência comprove a fixação de laços de afinidade e afetividade, e não seja constatada a ocorrência de má-fé ou qualquer das situações previstas nos arts. 237 ou 238 desta Lei. (grifo nosso)

Em análise ao artigo, primeiramente, faz-se possível identificar que essa modalidade não é aceita nos casos de adoção internacional, mas apenas de candidatos domiciliados no Brasil, bem como que essas três restrições acabaram por não abranger toda a realidade da adoção direta no Brasil.

Ocorre que, diante dessa negação de outras hipóteses as pessoas passam a ter medo de comparecer às Varas de Infância para regularizar sua situação com a criança, o que faz com que permaneçam com ela de modo irregular e influenciam a adoção ilegal (adoção à brasileira que será tratada adiante) ou as guardas fáticas que causam insegurança aos menores.

Isto porque, uma das medidas tomadas pelo poder judiciário em geral ao constatarem que houve uma entrega direta de uma criança pelos pais biológicos, é a busca e apreensão do menor e o encaminhamento aos abrigos que, na realidade, deveriam ser medidas excepcionais (artigo, 101, $\S 1^{\circ}$ do ECA) e são prejudiciais à formação de uma criança ou um adolescente, visto que não substituem nem minimamente os cuidados de um núcleo familiar afetuoso.

Ademais, quanto àqueles que defendem a proibição dessa modalidade de adoção encontram-se como justificativas o induzimento ao ato de compactuar com a "venda" de menores, o desrespeito ao cadastro e a não existência de certeza que os adotantes apresentam as condições necessárias para exercer a paternidade. Em relação a esta última justificativa, merece ser esclarecido seu não cabimento por meio do posicionamento de Eunice Ferreira Rodrigues Granato ${ }^{54}$ : 
Cada caso há de ser avaliado pelo juizado especial, e o juiz deverá decidir de acordo com as circunstâncias, sem se sentir tolhido por eventuais procedimentos burocráticos. Nossa proposta é no sentido de, em tais circunstâncias, manter os pretendentes à adoção na posse da criança e realizar os estudos necessários para se saber se estão eles em condições de adotar. Em caso positivo, regulariza-se a adoção. Em caso negativo, isto é, se não estão em condições de adotar, evidentemente a criança há de ser retirada de sua guarda, dando-se-lhe o destino conveniente. Estes estudos devem ser realizados com toda a brevidade possível, pois quanto mais tempo a criança ficar sob a guarda dos postulantes, mais chance haverá na formação de vínculo de afeto e, se a conclusão do estudo não lhes for favorável, a criança sofrerá.

Quanto à justificativa do respeito ao cadastramento, cabe ressaltar que, primordialmente, deve ser respeitado o melhor interesse da criança e, assim, respeitar a urgência das crianças e adolescentes de terem um lar, depois da dor da perda do convívio familiar. Sendo assim, o poder público deve aceitar que nem sempre o cadastro previsto no artigo 50 do ECA traz a melhor opção ao menor e nunca priorizar a análise de que seria injusto para com as famílias que estão na fila do cadastro, isso porque a adoção não deve funcionar como a busca de um filho para uma família, mas sim de uma família para uma criança, portanto, respeitemos a prevalência dessa última busca acima de tudo.

Felizmente, em forma de um sopro de esperança em meio ao preconceito que o instituto da adoção intuitu personae convive ao longo desses anos, no XII Congresso Brasileiro de Direito das Famílias e Sucessões, realizado em outubro de 2019, foi aprovado o Enunciado ${ }^{\circ} 35$ que estabelece:

"Nas hipóteses em que o processo de adoção não observar o prévio cadastro, e sempre que possível, não deve a criança ser afastada do lar em que se encontra sem a realização de prévio estudo psicossocial que constate a existência, ou não, de vínculos de socioafetividade".

Desta forma, aqueles que lidam diariamente com essa realidade de retiradas bruscas desses pequenos de seus núcleos familiares por meio de buscas e apreensões de crianças com o encaminhamento para abrigos, já entenderam a distorção do real melhor interesse da criança e do adolescente proporcionado por tal medida proporciona. $\mathrm{Na}$ realidade, finalmente entende-se que, pelo menos provisoriamente, o melhor lugar para aquele 
menor é com o núcleo com o qual ele se sente seguro e mantém vínculos afetivos, devendo quaisquer decisões que modifiquem essa realidade serem analisadas por profissionais capacitados, mediante uma equipe multidisciplinar, ao invés de ocorrerem atitudes impulsivas que podem ocasionar estragos irreparáveis na vida de uma criança ou adolescente.

No que se refere à sexta modalidade aqui apontada, a adoção afetiva, mais conhecida popularmente como adoção "à brasileira", na realidade em nada se trata do instituto jurídico da adoção, mas sim de um ato ilegal. Para piorar, ainda traz a conotação pejorativa de ligar o que é brasileiro com o que é ilegal - o famoso jeitinho brasileiro relacionado ao conceito do homem cordial, estabelecido pelo historiador Sérgio Buarque de Holanda.

Esta modalidade configura prática ilícita, tipificada como delito pelo artigo 242 do Código Penal:

Art. 242 - Dar parto alheio como próprio; registrar como seu o filho de outrem; ocultar recém-nascido ou substituí-lo, suprimindo ou alterando direito inerente ao estado civil: (Redação dada pela Lei no 6.898, de 1981)

Pena - reclusão, de dois a seis anos. (Redação dada pela Lei nº 6.898, de 1981)

Parágrafo único - Se o crime é praticado por motivo de reconhecida nobreza: (Redação dada pela Lei $n^{\circ} 6.898$, de 1981)

Pena - detenção, de um a dois anos, podendo o juiz deixar de aplicar a pena. (grifo nosso)

Portanto, não há como confundir a adoção "à brasileira" com a adoção consentida ou intuitu personae, visto que a primeira se trata de crime no qual ocorre o registro de nascimento sem que sejam respeitadas as regras do procedimento de adoção e, na maioria das vezes, a própria vontade dos pais biológicos, enquanto que na segunda modalidade os pais confiam na entrega do filho àquelas determinadas pessoas.

Como sétima modalidade temos a adoção homoparental, que na realidade nem teria a necessidade de ser tratada como uma modalidade em separado, mas diante da infeliz resistência por parte de segmentos conservadores, faz-se benéfica a sua ratificação. Nos primórdios, dado que 
sempre foi cabível a adoção individual independentemente da orientação sexual do candidato, apenas um dos integrantes dos casais homossexuais se candidatavam, adotavam a criança e o adolescente, no entanto essa habilitação se dava na prática de forma incompleta, pois não era realizado estudos sociais com o outro parceiro e, sem atender ao melhor interesse da criança, esse menor acabava tendo vínculos parentais apenas com um integrante do casal.

Felizmente, esse quadro de intolerância foi alterado quando o Supremo Tribunal Federal passa a admitir a adoção por casais do mesmo sexo, em razão do julgado a seguir:

DIREITO CIVIL. FAMÍLIA. ADOÇÃO DE MENORES POR CASAL HOMOSSEXUAL. SITUAÇÃO JÁ CONSOLIDADA. ESTABILIDADE DA FAMÍLIA. PRESENÇA DE FORTES VÍNCULOS AFETIVOS ENTRE OS MENORES E A REQUERENTE. IMPRESCINDIBILIDADE DA PREVALÊNCIA DOS INTERESSES DOS MENORES. RELATÓRIO DA ASSISTENTE SOCIAL FAVORÁVEL AO PEDIDO. REAIS VANTAGENS PARA OS ADOTANDOS. ARTIGOS $1^{\circ}$ DA LEI 12.010/09 E 43 DO ESTATUTO DA CRIANÇA E DO ADOLESCENTE. DEFERIMENTO DA MEDIDA. 1. A questão diz respeito à possibilidade de adoção de crianças por parte de requerente que vive em união homoafetiva com companheira que antes já adotara os mesmos filhos, circunstância a particularizar o caso em julgamento. 2. Em um mundo pós-moderno de velocidade instantânea da informação, sem fronteiras ou barreiras, sobretudo as culturais e as relativas aos costumes, onde a sociedade transforma-se velozmente, a interpretação da lei deve levar em conta, sempre que possível, os postulados maiores do direito universal. $3 . \mathrm{O}$ artigo $1^{\circ} \mathrm{da}$ Lei 12.010/09 prevê a "garantia do direito à convivência familiar a todas e crianças e adolescentes". Por sua vez, o artigo 43 do ECA estabelece que "a adoção será deferida quando apresentar reais vantagens para o adotando e fundarse em motivos legítimos". 4. Mister observar a imprescindibilidade da prevalência dos interesses dos menores sobre quaisquer outros, até porque está em jogo o próprio direito de filiação, do qual decorrem as mais diversas consequencias que refletem por toda a vida de qualquer indivíduo. 5. A matéria relativa à possibilidade de adoção de menores por casais homossexuais vincula-se obrigatoriamente à necessidade de verificar qual é a melhor solução a ser dada para a proteção dos direitos das crianças, pois são questões indissociáveis entre si.

6. Os diversos e respeitados estudos especializados sobre o tema, fundados em fortes bases científicas (realizados na Universidade de Virgínia, na Universidade de Valência, na Academia Americana de Pediatria), "não indicam qualquer inconveniente em que criancas sejam adotadas por casais homossexuais, mais importando a qualidade do vínculo e do afeto que permeia o meio familiar em que serão inseridas e que as liga a seus cuidadores". 7. Existência de consistente relatório social elaborado por assistente social favorável ao pedido da requerente, ante a constatação da estabilidade da família. Acórdão que se posiciona a favor do pedido, bem como parecer do Ministério Público Federal pelo acolhimento da tese autoral. 8. É incontroverso que existem fortes vínculos afetivos entre a recorrida e os menores - sendo a 
afetividade $\mathrm{o}$ aspecto preponderante a ser sopesado numa situação como a que ora se coloca em julgamento. 9. Se os estudos científicos não sinalizam qualquer prejuízo de qualquer natureza para as crianças, se elas vêm sendo criadas com amor e se cabe ao Estado, ao mesmo tempo, assegurar seus direitos, o deferimento da adocão é medida que se impõe. 10. O Judiciário não pode fechar os olhos para a realidade fenomênica. Vale dizer, no plano da "realidade", são ambas, a requerente e sua companheira, responsáveis pela criação e educacão dos dois infantes, de modo que a elas, solidariamente, compete a responsabilidade. 11 . Não se pode olvidar que se trata de situação fática consolidada, pois as crianças já chamam as duas mulheres de mães e são cuidadas por ambas como filhos. Existe dupla maternidade desde o nascimento das crianças, e não houve qualquer prejuízo em suas criações. 12. Com o deferimento da adoção, fica preservado o direito de convívio dos filhos com a requerente no caso de separação ou falecimento de sua companheira. Asseguramse os direitos relativos a alimentos e sucessão, viabilizando-se, ainda, a inclusão dos adotandos em convênios de saúde da requerente e no ensino básico e superior, por ela ser professora universitária. 13. A adocão, antes de mais nada, representa um ato de amor, desprendimento. Quando efetivada com o objetivo de atender aos interesses do menor, é um gesto de humanidade. Hipótese em que ainda se foi além, pretendendo-se a adoção de dois menores, irmãos biológicos, quando, segundo dados do Conselho Nacional de Justiça, que criou, em 29 de abril de 2008, o Cadastro Nacional de Adoção, 86\% das pessoas que desejavam adotar limitavam sua intenção a apenas uma criança. 14. Por qualquer ângulo que se analise a questão, seja em relação à situação fática consolidada, seja no tocante à expressa previsão legal de primazia à proteção integral das crianças, chega-se à conclusão de que, no caso dos autos, há mais do que reais vantagens para os adotandos, conforme preceitua o artigo 43 do ECA. Na verdade, ocorrerá verdadeiro prejuízo aos menores caso não deferida a medida. 15. Recurso especial improvido. (STJ, REsp: 889852 RS 2006/02091374, Relator: Ministro Luis Felipe Salomão, Quarta Turma, Data de Julgamento: 27/04/2010, Data de Publicação: DJe 10/08/2010) (grifo nosso)

Por fim, a adoção póstuma representa a adoção deferida após a morte do adotando, prevista no artigo $42, \S 6^{\circ}$ do ECA, desde que esteja presente a inequívoca manifestação da vontade. O parágrafo se refere aos casos em que o adotando veio a falecer no curso do procedimento, antes de prolatada a sentença; sentença esta que diferentemente da regra geral, serão dotadas de efeito ex tunc, retrocedendo à data do falecimento, constituindo-se o vínculo de filiação e o filho passa a ser herdeiro do candidato falecido.

Ocorre que, como interpretação extensiva ao dispositivo supracitado, a jurisprudência passou a admitir a adoção ainda que não tenha sido iniciado o processo antes do falecimento, bastando constatar que o falecido manifestou, em vida, inequívoca vontade de adotar, conforme dispõe o seguinte julgado do Superior Tribunal de Justiça: 
ADOÇÃO PÓSTUMA. Prova inequívoca. - O reconhecimento da filiação na certidão de batismo, a que se conjugam outros elementos de prova, demonstra a inequívoca intenção de adotar, o que pode ser declarado ainda que ao tempo da morte não tenha tido início o procedimento para a formalização da adoção. Procedência da ação proposta pela mulher para que fosse decretada em nome dela e do marido pré-morto a adoção de menino criado pelo casal desde os primeiros dias de vida. - Interpretação extensiva do art. 42, § $5^{\circ}$, do ECA. - Recurso conhecido e provido. (STJ - REsp: 457635 PB 2002/0104623-0, Relator: Ministro Ruy Rosado de Aguiar, Quarta Turma, Data de Julgamento: 19/11/2002, Data de Publicação: 17/03/2003).

Portanto, diante das modalidades de adoção apresentadas, cabe ressaltar que todas possuem em comum o fato de que o vínculo da consanguinidade da família biológica é sempre rompido e não resulta qualquer efeito jurídico, pessoal ou patrimonial, a não ser os impedimentos para o casamento (conforme artigo 1.521, inciso I do Código Civil), estando os filhos adotados quanto ao matrimônio sujeitos a duas ordens de impedimentos que dizem respeito tanto a dos vínculos cosanguíneos, quanto os decorrentes da união afetiva da adoção (incisos III e V do mesmo artigo do Código Civil). 


\section{INICIANDO A ADOÇÃO}

Uma criança ou um adolescente pode chegar à adoção por diversos caminhos, mas para esse instituto se formalizar necessariamente todos esses caminhos possuem uma condição comum: a inexistência do poder familiar, seja por meio da sua perda natural como, por exemplo, diante da morte dos genitores ou por meio da destituição do poder familiar por procedimento judicial resultante da vontade ou não dos genitores.

\subsection{DA ENTREGA}

O Estatuto da Criança e do Adolescente aborda pela primeira vez o tema da adoção no $\S 1^{\circ}$ do artigo 13 , quando determina que as gestantes ou mães que manifestem o desejo de entregar o filho à adoção serão, de forma obrigatória, encaminhadas à Justiça da Infância e da Juventude, ressalvando que para este ato não deve ser usado do constrangimento.

Este parágrafo foi incluso ao ECA pela Lei de Proteção à Primeira Infância (Lei n 13.257/2016) e tem seu conteúdo repetido no artigo 19-A, no entanto, os termos "obrigatoriamente"e "sem constrangimento" se encontram suprimidos e, portanto, devem ser interpretados de forma conjunta.

A realidade é: a população em geral tem o hábito de incutir nesta mulher a ideia de uma pessoa má que abandona o seu filho; e em decorrência disso, se faz necessária, primeiramente, a substituição do termo "abandono" pelo conceito da "entrega" ${ }^{\natural 5}$ e a busca pela compreensão do motivo que enseja esse ato: seja a necessidade econômica, familiar, profissional, emocional ou psicológica.

$\mathrm{O}$ ato de "compreender" se faz diferente do ato de "julgar" e conforme exposto neste estudo durante a abordagem da adoção intuitu personae, é essencial que a ideologia da maternidade como inerente a qualquer mulher seja desmistificada para que, assim, a mãe nessa posição 
de entrega pare de ser estigmatizada tanto pela sociedade como por quem tem que oferecer-lhe apoio e, de forma correta, receba toda a proteção que lhe garante a Carta Magna em seu artigo $6^{\circ}$ :

Art. $6^{\circ}$ São direitos sociais a educação, a saúde, a alimentação, o trabalho, a moradia, o transporte, o lazer, a segurança, a previdência social, a proteção à maternidade e à infância, a assistência aos desamparados, na forma desta Constituição. (grifo nosso)

Neste sentido, o amparo a esta gestante ou mãe faz-se essencial diante do dever que o Estado tem de cuidar dessas mulheres, independente do motivo que as levaram a tomar essa decisão, devendo este ser um cuidado livre de julgamento e que atenda as lacunas enfrentadas por muitas dessas mulheres nos moldes das políticas públicas de saúde existentes no país. A elas deve ser oferecido um ambiente seguro no qual possam realmente compreender as circunstâncias irreversíveis da adoção e o principal: as mulheres precisam ter a sua autonomia da vontade respeitada após a sua tomada de decisão, caso contrário podem ser induzidas a permanecerem com um filho que poderá sofrer ainda mais por isso.

Esse auxílio lhes é oferecido logo em seguida ao momento que comunicam sua vontade de entregar o filho à adoção, no qual são encaminhadas para serem ouvidas pela equipe multidisciplinar e, mediante sua concordância, para que sejam encaminhadas à rede pública de saúde e assistência social, conforme $\S 1^{\circ}$ do artigo 19-A.

A fim de difundir uma política de atenção à gestante, o Desembargador Eduardo Cortez de Freitas Gouvêa, Coordenador da Infância e Juventude do Tribunal de Justiça de São Paulo, elaborou a cartilha "Política de atenção à gestante: Apoio profissional para uma decisão amadurecida sobre permanecer ou não com a criança" ${ }^{, 56}$, isto porque

56 Política de atenção à gestante: Apoio profissional para uma decisão amadurecida sobre permanecer ou não com a criança, TJSP. Disponível em $\langle$ http://www.desenvolvimentosocial.sp.gov.br/a2sitebox/arquivos/documentos/873.pdf >. Acesso em 12 out. 2019. 
reconheceu que muitos profissionais que deveriam lidar com essa questão tinham atitudes negativas para com essa genitora:

"Quando a mulher procura um serviço público buscando ajuda para solucionar seu dilema frente à impossibilidade de ficar com a criança, não é raro defrontar-se com profissionais que tenham atitudes negativas e que compartilham de ideias preconceituosas com relação à sua atitude. Mas é preciso que as instituições e seus funcionários adotem posturas éticas e técnicas na perspectiva de superar os estigmas que acompanham essas mulheres."

Caso a mãe ou gestante decida seguir pelo caminho da adoção, é iniciada a busca por uma família extensa, teoricamente pelo prazo máximo de 90 (noventa) dias, prorrogável por igual período (conforme parágrafo $3^{\circ}$ do artigo 19-A). Ocorre que, dependendo do caso, passa a existir um conflito entre o que o Estatuto julga ser o melhor interesse da criança permanecer ao máximo mais próximo do núcleo da família natural - e o maior interesse da genitora - que por vezes não gostaria sequer que o núcleo da família natural saiba do nascimento da criança.

O Estatuto afirma que nos casos em que não haja a indicação do genitor e que não exista nenhum outro representante da família extensa apto a receber a guarda, deverá ser decretada a extinção do poder familiar e a colocação da criança sob a guarda provisória de quem estiver habilitado a adotá-la ou de entidade de acolhimento. Aqui cabe ser realizada uma ressalva importante: o prazo máximo de 180 (cento e oitenta dias) de busca pela família extensa totalizam 6 (seis) meses no qual essa criança pode ficar plenamente desamparada em algum abrigo e parece que o legislador se olvidou da rapidez essencial à proteção da primeira infância.

Prosseguindo, em relação à parte processual deste ato plenamente sigiloso ( $\$ 3^{\circ}$ do artigo 166 do ECA), o caput do artigo 166 do ECA dita o procedimento de forma que os genitores podem pedir expressamente para que o filho seja colocado em família substituta diretamente no cartório da respectiva Vara da Infância, por meio de petição assinada pelos próprios requerentes, dispensada a assistência de advogado. 
Nessa sequência, no prazo máximo de 10 (dez) a contar da data do protocolo da petição ou da entrega da criança em juízo, ocorre uma audiência no qual o Ministério Público irá ouvir os pais bológicos, neste momento devidamente assistidos por advogado ou defensor público, para verificar a concordância com a adoção e, consequentemente, o juiz declarará a extinção do poder familiar caso a vontade dos pais permaneça sendo a entrega $\left(\$ 1^{\circ}\right.$ do artigo 166 do ECA).

Cabe ressaltar que nenhuma decisão dos genitores será realizada sem as devidas orientações e esclarecimentos prestados pela equipe interprofissional ( $\$ 2^{\circ}$ do artigo 166 do ECA), ainda mais em se tratando da irrevogabilidade da adoção e, diante dessa consequência marcante, é necessário que o consentimento seja prestado por escrito para que tenha validade e seja ratificado na audiência citada no parágrafo anterior - que ocorre até 10 (dez) dias após o protocolo da petição ( $\$ 4^{\circ}$ do mesmo artigo).

Além disso, esse consentimento somente terá valor se for dado após o nascimento da criança $\left(\S 6^{\circ}\right)$, sendo retratável até a data da audiência do $\S 1^{\circ}$ e também até 10 (dez) dias contados da data da prolação da sentença de extinção do poder familiar, por meio do direito de arrependimento $\left(\$ 5^{\circ}\right.$ do artigo 166 do ECA).

O foco neste procedimento, bem como em todos que envolvam a vida desses pequenos cidadãos, deve sempre ser o do melhor interesse da criança, consoante com esse entendimento vejamos o difícil julgado proveniente do Superior Tribunal de Justiça no qual a Ministra Relatora Nancy Andrighi impediu o retorno da criança à mãe biológica após nove anos convivendo com os adotantes, a quem fora garantido o exercício da autoridade familiar:

CIVIL. ADOÇÃO. VÍCIO NO CONSENTIMENTO DA GENITORA. BOAFÉ DOSADOTANTES. LONGO CONVÍVIO DA ADOTANDA COM OS ADOTANTES.PREPONDERÂNCIA DO MELHOR INTERESSE DA CRIANÇA. 1. A criança adotanda é o objeto de proteção legal primário em um processo de adoção, devendo a ela ser assegurada condições básicas para o seu bem-estar e desenvolvimento sociopsicológico. 2. A constatação de vício no 
consentimento da genitora, com relação a entrega de sua filha para a adoção, não nulifica, por si só, a adoção já realizada, na qual é possível se constatar a boa-fé dos adotantes. 3. O alçar do direito materno, em relação à sua prole, à condição de prevalência sobre tudo e todos, dando-se a coacta manifestação da mãe-adolescente a capacidade de apagar anos de convivência familiar,estabelecida sobre os auspícios do Estado, entre o casal adotante,seus filhos naturais e a adotanda, no único lar que essa sempre teve, importa em ignorar o direito primário da infante, vista mais como objeto litigioso e menos, ou quase nada, como indivíduo,detentora, ela própria, de direitos, que, no particular, se sobrepõe aos brandidos pelas partes . 4. Apontando as circunstâncias fáticas para uma melhor qualidade devida no lar adotivo e associando-se essas circunstâncias à convivência da adotanda, por lapso temporal significativo - 09 anos-, junto à família adotante, deve-se manter íntegro esse núcleo familiar. 5. Recurso especial provido.(STJ - REsp: 1199465 DF 2010/0120902-0, Terceira Turma, Relatora Ministra Nancy Andrighi, Data de Julgamento: 14/06/2011, Data de Publicação: DJe 21/06/2011)

\subsection{DA PERDA DO PODER FAMILIAR}

$\mathrm{O}$ atual conceito de poder familiar deriva do instituto milenar do "pátrio poder", e se trata de instituto muito criticado pela doutrina, porque manteve o componente da antiga expressão "poder" e introduziu o termo "familiar", no entanto, a prerrogativa não é da família em geral, mas sim dos pais ${ }^{57}$.

Nesse hiato, a modificação do instituto não se deu apenas no quesito da nomenclatura, mas também em relação ao seu conteúdo, e, atualmente, diante da visão moderna esse poder familiar seria entendido como uma "autoridade paternal", conceito este que busca tirar a carga negativa e impositiva da palavra "poder" para dar a devida atenção ao que realmente deveria ser priorizado: a responsabilidade para com a criação dos filhos.

O poder familiar em sua melhor definição deveria, assim, ser entendido como uma responsabilidade parental que deve ter como norte o estabelecido nos artigos 22 do ECA c/c o artigo 1.634 do Código Civil, bem como interpretados em atenção aos direitos fundamentais constantes no artigo 227 da Constituição Federal de 1988: 
Estatuto da Criança e do Adolescente:

Art. 22. Aos pais incumbe o dever de sustento, guarda e educação dos filhos menores, cabendo-lhes ainda, no interesse destes, a obrigação de cumprir e fazer cumprir as determinações judiciais.

\section{Código Civil:}

Art. 1.634. Compete a ambos os pais, qualquer que seja a sua situação conjugal, o pleno exercício do poder familiar, que consiste em, quanto aos filhos:

I - dirigir-lhes a criação e a educação;

II - exercer a guarda unilateral ou compartilhada nos termos do art. 1.584;

III - conceder-lhes ou negar-lhes consentimento para casarem;

IV - conceder-lhes ou negar-lhes consentimento para viajarem ao exterior;

$\mathrm{V}$ - conceder-lhes ou negar-lhes consentimento para mudarem sua residência permanente para outro Município;

VI - nomear-lhes tutor por testamento ou documento autêntico, se o outro dos pais não lhe sobreviver, ou o sobrevivo não puder exercer o poder familiar;

VII - representá-los judicial e extrajudicialmente até os 16 (dezesseis) anos, nos atos da vida civil, e assisti-los, após essa idade, nos atos em que forem partes, suprindo-lhes o consentimento;

VIII - reclamá-los de quem ilegalmente os detenha;

IX - exigir que lhes prestem obediência, respeito e os serviços próprios de sua idade e condição

\section{Constituição Federal:}

Art. 227. É dever da família, da sociedade e do Estado assegurar à criança, ao adolescente e ao jovem, com absoluta prioridade, o direito à vida, à saúde, à alimentação, à educação, ao lazer, à profissionalização, à cultura, à dignidade, ao respeito, à liberdade e à convivência familiar e comunitária, além de colocá-los a salvo de toda forma de negligência, discriminação, exploração, violência, crueldade e opressão. (grifo nosso)

O poder familiar deriva da qualidade de pai e mãe e a sua perda acarreta necessariamente na perda dessa posição parental, perda esta que, conforme abordado anteriormente, é o pressuposto para a adoção e pode ocorrer de forma natural - pela morte de algum dos pais -, pela entrega consentida abordada no tópico anterior ou, por fim, via imposição de determinação judicial oposta à vontade dos pais. 
Em se tratando da primeira hipótese, no caso da morte de algum dos genitores, esse fato ocasiona diretamente o fim do poder familiar, dado que o instituto apenas pode ser exercido por um indivíduo vivo. No entanto, cabe explicar que caso apenas um dos pais do casal parental venha a falecer, o outro sobrevivente permanece incumbido do poder familiar e sua responsabilidade para com o filho permanece vigorando.

Nos casos de falecimento do pai ou da mãe, por exemplo, ocorre com frequiência a realização de posterior adoção unilateral nos casos em que a criança ou adolescente venha a ter um vínculo afetivo estabelecido com outra pessoa (em geral companheiro/cônjuge do pai sobrevivente), por meio de um processo de adoção que pode ser iniciado desde já diante da prévia inexistência do poder familiar.

Por outro lado, além da consequência natural ou da entrega voluntária, existe também a perda do poder familiar que deriva de medida protetiva excepcional e drástica tomada pelo Estado concretizada por meio de ação judicial, a fim de proteger o melhor interesse da criança e do adolescente.

Essa medida resulta, em sua maioria, nos casos no qual as crianças e adolescentes se encontram acolhidos - tanto por acolhimento familiar ou institucional - e não existe a possibilidade de reintegração familiar $\left(\S 8^{\circ}\right.$ do artigo 101 do ECA), sendo enviado um relatório elaborado por equipe especializada ao Ministério Público que contém a descrição pormenorizada das providências tomadas e recomendações para a destituição do poder familiar ( $\$ 9^{\circ}$ do mesmo artigo).

No momento em que recebe o relatório, o Parquet tem o prazo de 15 (quinze) dias para o ingresso com a ação de destituição do poder familiar, salvo se entender necessária a realização de estudos complementares ou de outras providências $\left(\S 10^{\circ}\right.$ do artigo 101). 
Ademais, não apenas o Ministério Público é responsável pelo ajuizamento desta demanda, mas também quem tenha legítimo interesse por provocar o início da ação de perda ou suspensão do poder familiar (artigo 155 do ECA). Cabe salientar que ao Parquet essa responsabilidade se torna uma obrigação em funções das atribuições previstas à instituição no inciso III e VIII do artigo 201 do Estatuto:

Art. 201. Compete ao Ministério Público:

$(\ldots)$

III - promover e acompanhar as ações de alimentos e os procedimentos de suspensão e destituição do poder familiar, nomeação e remoção de tutores, curadores e guardiães, bem como oficiar em todos os demais procedimentos da competência da Justiça da Infância e da Juventude;

(...)

VIII - zelar pelo efetivo respeito aos direitos e garantias legais assegurados às criancas e adolescentes, promovendo as medidas judiciais e extrajudiciais cabíveis; (grifo nosso)

Ademais, nesse pedido inicial, havendo motivo grave poderá a autoridade judiciária - ouvido o Ministério Público - decretar a suspensão liminar ou incidentalmente do poder familiar, até o julgamento definitivo da causa (artigo 157 do ECA). Diante dessa medida, a criança ou adolescente fica confiado à pessoa idônea, mediante termo de responsabilidade.

A doutrinadora Maria Berenice Dias entende ser função do Parquet requerer no pedido inicial, a título de tutela antecipada de urgência de natureza cautelar (artigo 300 do Código de Processo Civil), que a criança seja entregue desde já à guarda de quem está habilitada à adotá-la diante da probabilidade e o perigo de dano se a mesma permanecer institucionalizada ${ }^{58}$.

Essa visão se fundamenta no fato de que ao entendimento de Maria Berenice Dias - e conforme ocorre na maioria dos casos - a ação de perda do poder familiar é interposta depois de esgotadas todas as possibilidades 
de reinserção do filho junto aos pais ou na família extensa, sendo obviamente descabido nesses casos que a criança permaneça institucionalizada enquanto o processo tramita, o que de um modo geral, pode durar muitos anos.

Em regra, após ter recebido a petição inicial o juízo deve, após o despacho de citação, obrigatoriamente, determinar a realização de estudo social ou perícia por equipe interprofissional ou multidisciplinar para comprovar a presença de uma das causas de suspensão ou destituição do poder familiar ( $\$ 1^{\circ}$ do artigo 157 do ECA), afinal, o juízo apesar de toda sua experiência não foi capacitado da forma como um profissional de saúde ou assistente social para tecer tal parecer.

Posteriormente, o requerido que deve ser citado pessoalmente, salvo se esgotado todos os meios para sua realização - que se dá quando por 2 (duas) vezes o oficial de justiça houver procurado o citando em seu domicílio ou residência sem o encontrar, devendo (i) no caso de suspeita de ocultação realizar citação por hora certa nos termos do artigo 252 e seguintes do Código de Processo Civil ou (ii) no caso dos estar em local incerto e não sabido ocorrer a citação por edital no prazo de 10 (dez) dias, em publicação única, dispensado o envio de ofícios para localização - , para, assim, oferecer resposta escrita no prazo de 10 (dez) dias (artigo 158 do ECA).

Caso o pedido inicial não venha a ser contestado e já tenha sido concluído o estudo social ou a perícia do $\S 1^{\circ}$ do artigo 157 , a autoridade judiciária abre vista ao Ministério Público, salvo quando este for requerente, pelo prazo de 5 (cinco) dias e deverá inclusive, decidir em igual prazo (artigo 161, caput).

Ocorre que, para que tal decisão ocorra, devem ser feitas algumas ressalvas: primeiramente, o juízo de ofício, a requerimento de alguma das partes ou por pedido do Parquet realizará a oitiva das testemunhas, bem como a oitiva da criança ou do adolescente, desde que respeitado o seu 
estágio cognitivo, de desenvolvimento e de compreensão sobre as medidas que serão a ele aplicadas (artigo $161, \S \S 1^{\circ}$ e $3^{\circ}$ ).

Além das oitivas apontadas acima, faz-se essencial a oitiva dos pais sempre que os mesmos forem identificados e estiverem em local conhecido, apenas não ocorrendo caso os mesmos optem por livre e espontânea vontade em não comparecer à Justiça desde que devidamente citados (artigo $\left.161, \S 4^{\circ}\right)$.

Entretanto, no caso de haver contestação o Ministério Público terá o direito de ter vista aos autos por 5 (cinco) dias, sempre ressalvado quando o órgão for o requerente da ação, e o juízo deverá designar desde logo a audiência de instrução e julgamento (artigo 162, caput) na qual caberão todas as oitivas apontadas anteriormente, manifestando-se a equipe social, o requerente, o requerido e o Parquet pelo tempo de 20 (vinte) minutos cada um, prorrogáveis por mais $10(\mathrm{dez})$ minutos $\left(\S 2^{\circ}\right.$ do artigo 162$)$.

A sentença deve ser proferida na própria audiência de instrução e julgamento, ou seja, o procedimento prevê a ocorrência de uma audiência una, mas excepcionalmente poderá o juízo determinar a designação de data para a leitura da sentença, desde que a mesma seja feita em um prazo de no máximo 5 (cinco) dias (artigo 162, $\S 3^{\circ}$ ) e é por meio desta que o juiz pode determinar a inclusão da criança na família substituta.

Ademais, o Estatuto prevê que todo o procedimento deverá ter um prazo máximo de 120 (cento e vinte) dias, realidade esta que, infelizmente, nem sempre vem a ser respeitada.

Isto porque, a Defensoria Pública - tanto na posição de defensora de um dos pais, quanto na função de curadora quando um deles não é encontrado (artigo 272, II do CPC) - costuma esgotar todas as possibilidades recursais e, pasmem, isso ocorre mesmo quando os pais são revéis, ou seja, a instituição atua de forma afrontosa para com as normas 
protetivas à infância e à juventude e oposta ao resguardo do melhor interesse desses menores.

Quando se chega ao fim desse processo, depois do trânsito em julgado desta sentença, ocorrerá a inclusão da criança ou do adolescente no cadastro previsto no artigo 50 do ECA, sendo este o Sitema Nacional de Adoção - SNA, no qual o juízo terá o prazo de 48 (quarenta e oito) horas para tomar essa providência, conforme dispõe o artigo $50, \S 8^{\circ}$ do ECA. 


\section{DA HABILITAÇÃO DOS PAIS DE AFETO}

No momento em que a criança passa a integrar o novo cadastro, o Sistema Nacional de Adoção, inicia-se a busca de uma família para aquele menor. Essa busca é denominada vinculação e, atualmente, para que seja iniciada, os candidatos devem realizar um pré-cadastramento por meio de um formulário eletrônico ${ }^{59}$ no qual informarão primeiramente as (i) características do pretendente: se querem realizar a adoção na região do município, do Estado ou nacional - de forma que, caso selecionem a última opção, devem marcar os Estados (podendo selecionar desde apenas um até os 26 Estados e o Distrito Federal) que desejam realizar a adoção, visto que pode ocorrer a necessidade de deslocamento a esses outros locais -, se são casados ou convivem em união estável e, caso positivo, a data em que a referida união se iniciou.

Em uma segunda etapa do pré-cadastramento os candidatos devem preencher os seus dados pessoais e, por fim, as características das crianças e adolescentes a serem adotados (idade mínima e máxima - incluindo ano e meses -, a quantidade a ser adotada, o gênero, a aceitação de deficientes físicos, mentais, com doença detectada ou com doenças infecto-contagiosas, se aceitam irmãos e se possuem alguma preferência étnica).

Após esse processo de pré-cadastramento os candidatos devem se dirigir à Vara de Infância e Juventude para iniciar o procedimento de habilitação e, apenas após a sentença positiva desse procedimento, que os candidatos serão incluídos no SNA.

A autoridade judiciária foi incumbida da responsabilidade de manter um registro de pessoas interessadas pela adoção (artigo 50 do ECA) e o Ministério Público tem o dever de fiscalizar, devendo sempre se manifestar acerca da concessão de autorização ou não do pedido de cadastramento dos candidatos ( $\S 1^{\circ}$ do mesmo artigo).

59 Site do CNJ do Sistema Nacional de Adoção, área de pré-cadastramento. Disponível em <https://www.cnj.jus.br/sna/indexPrecadastro.jsp>. Acesso em 23 out 2019. 
A fim de que ocorra o procedimento de habilitação de forma consciente, a inscrição dos postulantes deve ser precedida de um período de preparação psicossocial e jurídica que é orientado pelas equipes técnicas da Justiça da Infância e da Juventude (artigo 50, $\S 3^{\circ}$ do ECA). Na cidade do Rio de Janeiro, mais especificamente em relação à $1^{\text {a }}$ Vara da Infância, da Juventude e do Idoso (que abrange a área da Zona Sul), essa preparação costuma durar, aproximadamente, 4 (quatro) a 5 (cinco) meses e se dá, inicialmente, pela participação em uma reunião informativa realizada pela equipe técnica da respectiva Vara na qual o procedimento é brevemente explicado e, ao fim da reunião, ocorre o encaminhamento dos candidatos para 4 (quatro) reuniões obrigatórias em algum dos Grupo Institucional de Apoio à Adoção (GIAA) indicados.

Esse estágio inicial de preparação ao procedimento de habilitação encontra no Estatuto a recomendação de incluir, sempre que possível e recomendável, o contato com crianças e adolescentes em acolhimento familiar ou institucional em condições de serem adotados (artigo 50,§ $4^{\circ}$ ). Infelizmente, essa medida não é uma realidade na maior parte dos juízos especializados, visto que muitos sequer possuem equipe técnica especializada para acompanhar esse contato entre habilitandos e os menores.

Felizmente, no Rio de Janeiro, a $3^{\text {a }}$ Vara da Infância, da Juventude e do Idoso criou o projeto "Abrigo de Portas Abertas" disposto no artigo $50, \S 4^{\circ}$ e artigo $197-\mathrm{C}, \S \S 1^{\circ}$ e 2 e diante das demandas de habilitandos e habilitados em entrar em contato com as crianças. Essas visitas monitoradas passaram a ser obrigatórias para a concessão da habilitação para adoção e são realizadas uma vez ao mês por membros voluntários componentes do Grupo de Apoio à Adoção Ana Gonzaga II,

\footnotetext{
60 Projeto "Abrigo de Portas Abertas". Disponível em $\langle$ http://infanciaejuventude.tjrj.jus.br/boaspraticas/docs/projeto-portasabertas.pdf>. Acesso em 15 out 2019.
} 
acompanhados de uma psicóloga, também voluntária, do grupo de psicólogos e psicanalistas denominado "Singularizando".

A visitação do projeto ocorre desde agosto de 2014 e inicia-se com uma rápida conversa com os habilitandos ou habilitados em fase de renovação, na qual são esclarecidos os objetivos e regras como: a visita não se trata de busca de criança e sim de momentos de lazer para os menores; de que forma interagir com uma criança com deficiência evitando demonstrar pena; a proibição de realizar perguntas à criança/adolescente acerca dos motivos que ensejaram o acolhimento institucional, e, obviamente, jamais falar sobre adoção.

A duração dessa visita é de aproximadamente 2 (duas) horas, nas quais os habilitandos ou habilitados fazem um lanche para as crianças e depois brincam com as mesmas, por meio de diversas atividades lúdicas. Satisfatoriamente, o resultado desse projeto é proveitoso dado que algumas crianças foram adotadas, inclusive crianças com patologias crônicas.

Sendo assim, após essa preparação que varia de acordo com cada Vara da Infância e Juventude, os postulantes à adoção domiciliados no Brasil devem apresentar petição inicial na qual conste a (i) qualificação civil completa, (ii) dados familiares, (iii) cópias autenticadas de certidão de nascimento ou casamento/escritura de união estável, (iv) cópias das cédulas de identidade e CPF, (v) comprovante de renda e de residência, (vi) atestados de sanidade mental, (vii) certidão de antecedentes criminais e (viii) certidão negativa de distribuição cível, conforme determina o artigo 197-A do ECA.

Na cidade do Rio de Janeiro, a $1^{\text {a }}$ Vara da Infância, da Juventude e do Idoso, além de exigir toda a documentação determinada pelo ECA ainda requer declarações de idoneidade moral, elaborada por duas pessoas e, conforme anteriormente informado, o comprovante de participação em reuniões de Grupo Institucional de Apoio à Adoção (GIAA), cabendo ressaltar que não se faz necessária a constituição de advogado para este 
procedimento de habilitação - visto que entregam inclusive um modelo semi-pronto de petição de habilitação - e as certidões negativas do inciso VII e VIII do artigo 197-A podem ser retiradas diretamente pelo candidato e de forma gratuita.

Posteriormente, a petição de habilitação é encaminhada à autoridade judiciária que terá o prazo de 48 (quarenta e oito) para dar vista ao Ministério Público e este último deve em 5 (cinco) dias: apresentar quesitos a serem respondidos pela equipe interprofissional, requerer a designação de audiência para oitiva dos postulantes e, também, requerer a juntada de documentos complementares e a realização de outras diligências que entenderem necessárias (artigo 197-B do ECA).

Portanto, a equipe interprofissional que atuou no procedimento preparatório para a habilitação também é responsável por elaborar estudo psicossocial que conterá subsídios que permitam aferir a capacidade e o preparo dos postulantes para o exercício de uma paternidade ou maternidade responsável (artigo 197-C do ECA) durante o próprio procedimento de habilitação.

Após a realização do estudo psicossocial e da manifestação do Ministério Público, o juízo terá 48 (quarenta e oito) horas para decidir sobre as exigências que forem requeridas pelo Parquet e determinará a juntada do estudo, podendo, conforme o caso em concreto, designar a audiência de instrução e julgamento.

Caso a autoridade judiciária decida por indeferir as exigências do Ministério Público ou não sendo requerida nenhuma exigência, será aberto vista ao Parquet por 5 (cinco) dias (artigo 197-D do ECA).

Sendo assim, chegando ao fim do procedimento de habilitação, nos casos em que for designada audiência ou nos casos em que já tiverem sido cumpridas as exigências do Ministério Público e não houver necessidade qualquer audiência, a autoridade judiciária decidirá sobre a habilitação, no 
prazo de 5 (cinco) dias e caso seja deferida, o juiz deverá realizar o cadastro dos postulantes (artigo, 197-E do ECA).

Atualmente, esse cadastro é realizado no sistema do Sistema Nacional de Adoção, e os postulantes passam a integrar uma lista cronológica, conforme o sistema que será abordado adiante.

Ademais, em relação à habilitação cabe ressaltar que a competência é a do juízo do domicílio do candidato, de forma que o fato de mudar de residência não impõe a necessidade de nova inscrição, já que o novo sistema justamente tem abrangência nacional. Ocorre que, conforme expõe Maria Berenice ${ }^{61}$, visto que a preferência é dada aos candidatos do domicílio do adotando, ressaltando que nada impede que a adoção seja levada a efeito em comarca distinta:

APELAÇÃO. HABILITAÇÃO PARA ADOÇÃO. CASAL INSCRITO NO CADASTRO DE ADOÇÕES EM COMARCA DIVERSA E QUE PLEITEIA A ADOÇÃO DO INFANTE. CABIMENTO. Nos termos do art. 50 do ECA, cada comarca deve manter o seu próprio cadastro de pessoas interessadas em adotar e de crianças e adolescentes disponíveis para adoção. Se o casal que postula a adocão está habilitado para a adocão na comarca de Farroupilha, nada impede que venha a adotar o infante na comarca de Caxias do Sul, pois também existe um cadastro nacional. Ademais, o casal possui plenas condições para adoção, o que restou atestado no estudo social e laudo psicológico. RECURSO PROVIDO. (TJRS, Apelação Cível no 70067076836 , Sétima Câmara Cível, Desembargadora Relatora: Liselena Schifino Robles Ribeiro, Data de Julgamento: 02/12/2015, Data de Publicação DJ 07/12/2015) (grifo nosso).

Desta forma, a Resolução n 289/2019 prevê expressamente que em caso de mudança de domicílio, o pretendente deve comunicar de imediato à respectiva Vara, juntar novo comprovante de residência nos autos do processo original ou requerer pessoalmente a remessa dos autos para a Vara competente no novo endereço.

A supracitada Resolução em seu artigo $5^{\circ}$ do Anexo II, ainda prevê que o magistrado da nova comarca avaliará a necessidade de realização de novo estudo social e cabe ressaltar que essa mudança de domicílio não 
enseja a alteração da data-base do cadastramento (que interfere diretamente na sua ordem na fila).

Por derradeiro, o Estatuto da Criança e do Adolescente também estabelece que todo esse procedimento de habilitação, desde o seu início via petição inicial, tenha o prazo máximo de duração de 120 (cento e vinte) dias para a sua conclusão, prorrogáveis por igual período, mediante decisão fundamentada da autoridade judiciária (artigo 197-F).

\subsection{DOS CADASTROS}

O primeiro cadastro nacional de adoção foi regulado pela Resolução $\mathrm{n}^{\circ} 54$ de 2008 do CNJ c/c a Lei n ${ }^{\circ} 12.090 / 2009$ e tinha o objetivo de ordenar a colocação de crianças e adolescentes em família substituta, na modalidade de adoção, obedecendo à anterioridade dos interessados e às peculiaridades de cada adotando ${ }^{62}$. Essa ferramenta que veio para auxiliar o processo de adoção sofreu modificações ao longo do período de 10 (dez) anos que, infelizmente, nem sempre foram benéficas.

Algumas dessas modificações e de certa forma até a própria redação das respectivas normas constantes no ECA pela Lei $\mathrm{n}^{\circ} 12.090 / 2009$, acabaram por desvirtuar do foco de crianças e adolescentes como os principais sujeitos de direito, mediante uma lógica de busca de filhos para os candidatos cadastrados (artigo 197-E) ao invés da busca de pais para os filhos cadastrados:

Art. 197-E. Deferida a habilitação, o postulante será inscrito nos cadastros referidos no art. 50 desta Lei, sendo a sua convocacãa para a adocão feita de acordo com ordem cronológica de habilitacão e conforme a disponibilidade de criancas ou adolescentes adotáveis.

$\S 1$ A ordem cronológica das habilitações somente poderá deixar de ser observada pela autoridade judiciária nas hipóteses previstas no $\S 13$ do art. 50 desta Lei, quando comprovado ser essa a melhor solução no interesse do adotando. (grifo nosso) 
Uma pergunta importante surge neste instante acerca do cadastramento: quem seriam essas crianças e esses adolescentes em condições de serem adotados constantes no caput do artigo 50? De acordo com o Estatuto e com o artigo $3^{\circ}$ do anexo I da Resolução n 289/2019 do $\mathrm{CNJ}$, as crianças que podem vir a integrar o cadastro são aquelas (i) cujos pais tiveram o poder familiar destituído ou extinto por processo judicial transitado em julgado, (ii) as crianças órfãs ou (iii) aquelas que ambos os genitores são desconhecidos.

O próprio Estatuto estabelece no $\S 10^{\circ}$ do artigo 19-A que os recémnascidos e crianças acolhidas e não procuradas pelas suas famílias no prazo de 30 (trinta) dias, contados a partir da data do acolhimento, serão cadastradas para adoção. Ademais, em medida excepcional, é possível o cadastramento de crianças e adolescentes sob forma cautelar diante da não ocorrência do trânsito em julgado dos processos de extinção ou destituição do poder familiar, cabendo ressaltar aos candidatos o risco jurídico decorrente dessa adoção (artigo $4^{\circ}$ do anexo I da Resolução ${ }^{\circ}$ 289/2019 do $\mathrm{CNJ}$ ), visto se tratar de medida provisória que corre riscos de ser revertida.

Quanto ao prazo para essa inserção no cadastro (atualmente, o SNA) na área de crianças aptas à adoção, o $\$ 8^{\circ}$ do artigo 50 estabelece que a autoridade competente tem o prazo de 48 (quarenta e oito) horas para realizar essa tarefa.

Sendo assim, realizados os devidos cadastramentos dessas crianças na área de aptas à adoção do SNA, a consulta para o estabelecimento de uma vinculação com os pretendentes se inicia de forma regional, ou seja, a consulta inicia de forma concentrada e depois se expande caso não seja possível a colocação em família cadastrada na comarca de origem, passando a consultar o cadastro Estadual e, caso ao resultado da consulta permaneça negativo, em um terceiro momento ocorrerá uma busca em todo o território nacional. 
Desta forma, quando se tem um perfil mais restrito a tendência é de que aqueles habilitados fiquem mais limitados a sua comarca, enquanto os que têm um perfil mais amplo podem acabar adotando fora da comarca, desde que tenham escolhido a opção de cadastro para além de seu município, opção esta que passou a ser uma realidade com o advento do novo Sistema Nacional de Adoção e Acolhimento, que será tratado posteriormente.

Sendo assim, é possível concluir que existem dois balizadores do cadastro: a data de sentença da habilitação (artigo 197-E do ECA) e a localidade de quem se habilitou. Cabe ressaltar que, apesar de o antigo cadastro, o CNA, ter sido criado para ser um cadastro nacional, o mesmo não funcionava regularmente e ensejou a utilização de métodos alternativos visando sanar esse problema, dentre eles o da busca ativa que também será abordado adiante.

Neste momento, a fim de compreender melhor esse cadastro passivo de tantas críticas é necessário entender a sua origem. O Cadastro Nacional de Adoção foi criado em abril de 2008 por meio da Resolução ${ }^{\circ} 54$ do CNJ; essa Resolução determinava a criação de um banco de dados que ficaria sob controle do $\mathrm{CNJ}$ no qual passariam a constar as crianças de todas as unidades da federação aptas à adoção, bem como os pretendentes devidamente habilitados e residentes em todo o território nacional.

Por meio desse primeiro cadastro era permitida também a manutenção de sistemas de cadastramentos próprios do respectivo juízo, como uma forma de cadastro paralelo, mas com a condição de que mantivesse devidamente alimentado o cadastro nacional, em respeito ao disposto no parágrafo $5^{\circ}$ do artigo 50 do Estatuto.

Esse Cadastro Nacional sofreu alterações por meio de outras resoluções, dentre elas as Resolução $\mathrm{n}^{\circ} 93$ de outubro de 2009 - que não apresentou alterações significativas - e a n ${ }^{\circ} 190$ de abril de 2014 - na qual foi: (i) determinado a inserção de um "subcadastro" no qual passassem a 
constar os candidatos à adoção internacional para serem consultados como última medida, caso não ocorresse adoção por candidatos residentes no Brasil; (ii) estabeleceu normas de gerência de outro cadastro, o Cadastro Nacional de Crianças e Adolescentes Acolhidos e, por fim, (iii) determinou que os cadastros estaduais e das respectivas comarcas passassem a ser absorvidos realmente por um único cadastro, o Cadastro Nacional.

Na prática o Cadastro Nacional sofreu algumas alterações e o último modelo que estava em vigor no período de fevereiro de 2019 foi considerada a pior ferramenta até então utilizada pelos profissionais da área. Por meio deste modelo os profissionais das respectivas Varas só conseguiam visualizar as famílias da própria comarca, fato que, obviamente, não ajudou e pelo contrário, retrocedeu para um sistema mais limitado que resultou no aumento dos casos de busca ativa, como válvula de escape.

Sendo assim, o que seria esse método alternativo intitulado como busca ativa? Ela se trata de uma estratégia de busca de famílias para as crianças mais velhas e adolescentes, para grupos de irmãos, para menores com deficiência ou enfermidade, ou seja, um método de busca independente de famílias já cadastradas para grupos de crianças e adolescente com menores chances de se encaixarem no perfil normalmente escolhido pelos candidatos. Esse método foi abordado pela primeira vez no Plano Nacional de Promoção e Defesa do Direito de Crianças e Adolescentes à Convivência Familiar e Comunitária, um plano que deveria valer do ano de 2007 a 2015, mas que teoricamente ainda é utilizado, visto que nenhum outro foi elaborado para substituí-lo.

No Plano supracitado, a busca ativa estava expressamente apontada mas não de forma restritiva - para as crianças maiores e adolescentes, com deficiência, portadoras do vírus HIV, afrodescendentes, com transtorno mental e grupos de irmãos. No entanto, cabe apontar que, atualmente e de forma muito satisfatória, a realidade das crianças enquadradas no perfil da 
busca ativa se alterou, não sendo a raça ou a portabilidade do vírus do HIV, por exemplo, um empecilho à adoção, visto que as crianças pequenas em geral encontram facilmente um novo lar, entretanto as crianças maiores de 10 (dez) anos ou adolescentes são as que, atualmente, apresentam maior dificuldade em se encaixarem nos perfis escolhidos.

Diante do fato de que a plataforma do Cadastro Nacional em vigor até fevereiro de 2019 não era eficiente, ocorreu a implantação de um novo modelo de cadastro, uma nova versão do CNA, que conforme citado anteriormente se trata do Sistema Nacional de Adoção e Acolhimento. Esse novo sistema trouxe consigo uma nova proposta: a possibilidade de visualização da criança de forma mais holística não apenas tratando da adoção e habilitação, mas sim de todo o histórico daquela criança, por meio de informações inseridas sobre o seu acolhimento e que podem ser editadas por diferentes profissionais, até mesmo pelos membros do Ministério Público.

Esse novo sistema já estava sendo utilizado em todo o Estado do Espírito Santo e serviu de modelo para a modificação do cadastro Nacional, prometendo trazer a integração do Cadastro Nacional de Adoção como Cadastro Nacional de Crianças e Adolescentes Acolhidos que antes eram operados em separado.

O novo sistema é regulamentado pela Resolução ${ }^{\circ} 289$ de agosto de 2019 e também tem uma dinâmica de pré-cadastramento dos candidatos de forma que aqueles que utilizam o cadastro podem acessar informações como a Vara da comarca que o candidato mora, editar o perfil dos candidatos habilitados e o da criança a ser adotada. Após o procedimento de habilitação e o respectivo cadastramento no sistema, o candidato terá uma senha pela qual pode acessar ao sistema e constatar em qual número da fila estadual ele se encontra.

Essa inovação advinda com o fato de o candidato passar a ter acesso ao seu respectivo número na fila estadual trouxe à tona um dilema acerca do 
acesso às informações, que apesar de ter sido ampliada, ainda ocorre de forma muito restrita e sem nenhuma explicação para tal limitação. Essa prática configura um desrespeito ao artigo $5^{\circ}$, inciso XXXIII da Constituição Federal que garante o acesso à informação de interesse particular derivados de órgãos públicos e à Lei de Acesso à Informação ${ }^{\circ}$ 12.527 de 2011, em seu artigo $3^{\circ}$, que estabelece os princípios básicos da administração pública em relação ao acesso às informações nos seus diferentes procedimentos e que não pode deixar de ser observado quanto ao procedimento de adoção.

Ora, a obtenção, por exemplo, de informações além do seu número em uma fila favoreceriam não apenas aos candidatos que permanecem ansiosos e perdidos quanto à situação temporal da sua espera, mas também às crianças e adolescentes, visto que caso, por exemplo, existisse uma filtragem por perfil de crianças disponíveis à adoção, os adotantes poderiam ter uma previsão de quanto tempo aproximadamente duraria a espera por crianças do perfil pré-estabelecido e poderiam até ser incentivados a questionar de forma saudável o motivo da escolha desse perfil e a possibilidade de alteração do mesmo.

O SNA também proporciona o acesso as estatísticas em tempo real, ou seja, passou a constar no sistema itens em cores diferentes que determinam diferentes estágios que aquela criança ou adolescente se encontra, por exemplo, a cor vermelha passa a constar quando já passou o tempo previsto de institucionalização daquele menor, a cor amarela se refere àquelas que estão chegando perto do término do prazo de institucionalização e a cor azul retrata as crianças que passaram a estar inativas no sistema.

O novo sistema também passou a abranger os pretendentes nacionais e internacionais em uma mesma plataforma, sendo que esses últimos permanecem sendo chamados para a vinculação com a criança ou o adolescente apenas quando forem esgotadas as buscas por pretendentes no 
território nacional, momento em que o juízo competente tem o prazo máximo de 5 (cinco) dias para iniciar as buscas internacionais.

Dentre as novidades existentes na habilitação, cabe ressaltar que o prazo dela se mantém por três anos, devendo ser renovada até o seu vencimento e caso não seja, a habilitação permanecerá suspensa por 30 (trinta) dias, prazo no qual o postulante ainda poderá requerer a renovação e, caso este pedido não seja feito, a habilitação será arquivada e com imediata inativação no sistema.

O pretendente pode ainda pedir a renovação da habilitação e não perder a sua data-base na fila (aquela correspondente a data de sentença de habilitação) caso realize a renovação 120 (cento e vinte) dias antes de terminar o prazo de 3 (três) anos de vigência.

No que se refere à vinculação, o encontro entre candidatos e crianças aptas à adoção, quando esta for iniciada a habilitação do pretendente ficará suspensa para novas consultas e o juízo terá o prazo de 15 (quinze) dias para comunicar o fato ao pretendente. A comunicação é realizada, preferencialmente, por meio eletrônico e caso não seja realizada pelo magistrado, o sistema automaticamente encaminhará correspondência eletrônica ao pretendente, convocando-o para se manifestar sobre o seu interesse em conhecer a criança ou o adolescente. Tal medida traz extremo benefício ao procedimento, visto que a má gestão ou organização de determinado juízo não ocasionará um retardo prejudicial, principalmente, aos menores espalhados nos abrigos pelo Brasil.

Sendo assim, é exclusiva a responsabilidade do pretendente de manter os seus dados atualizados no SNA, visto que caso o juízo tente entrar em contato e os dados estejam desatualizados, este fato será encarado como uma recusa injustificada ensejando as consequências do artigo 197-E, $\S 4^{\circ}$ do ECA: 
Art. 197-E. Deferida a habilitação, o postulante será inscrito nos cadastros referidos no art. 50 desta Lei, sendo a sua convocação para a adoção feita de acordo com ordem cronológica de habilitação e conforme a disponibilidade de crianças ou adolescentes adotáveis.

(...)

§ 4 Após 3 (três) recusas injustificadas, pelo habilitado, à adocão de criancas ou adolescentes indicados dentro do perfil escolhido, haverá reavaliação da habilitação concedida. (grifo nosso)

Depois de consultado, o pretendente terá o prazo de 2 (dois) dias úteis para manifestar seu interesse em conhecer a criança ou o adolescente, sendo que em caso de omissão ou desinteresse será realizada outra busca por vinculação. No entanto, caso seja manifestado interesse o pretendente deverá comparecer ao juízo que o convocou no prazo de 5 (cinco) dias, prorrogáveis pelo magistrado mediante justificação adequada, a fim de iniciar os procedimentos de adoção. 


\section{O PROCESSO DE ADOÇÃO}

Após a realização da vinculação entre os pretendentes à adoção e as crianças e adolescentes aptas a serem adotados, diante da manifestação positiva dos postulantes, dá-se início ao estágio de convivência (artigo 46 do ECA) pelo prazo máximo de 90 (noventa) dias, sempre observando as peculiaridades de cada caso que pode ensejar a prorrogação do prazo por igual período, mediante decisão fundamentada da autoridade judiciária.

Essa convivência pode ser dispensada apenas nos casos em que o menor já esteja sob guarda ou tutela do adotante durante tempo suficiente para que seja possível avaliar a convivência e a constituição de vínculo afetivo.

No entanto, no que se refere à guarda de fato, o ECA assume no $\S$ $2^{\circ}$-A do artigo 46 que esse instituto por si só não autoriza a dispensa o período de convivência, ocasionando uma enorme incongruência com a preservação do melhor interesse da criança, dado que o foco para ocorrência ou não dessa etapa deveria se basear primordialmente no estabelecimento de laços afetivos e saudáveis daquela família com o menor, de forma que certas formalizações deveriam ser mitigadas em prol de um benefício maior, sendo importante destacar que o ato informal ora tratado não se trata de ato ilícito!

Além disso, para que seja possível a realização do estágio de convivência, faz-se essencial o acompanhamento por equipe multidisciplinar da respectiva Vara e o mesmo deve ser cumprido dentro do território nacional, preferencialmente na comarca de origem da criança e do adolescente.

A partir do dia seguinte à data do término do estágio de convivência, os pretendentes terão 15 dias para ajuizar a ação de adoção ${ }^{63}$, processo este que não está regulamentado de forma concentrada no ECA, mas sim diluído

63 Passo a passo da adoção. Disponível em <https://www.cnj.jus.br/programas-eacoes/adocao/passo-a-passo-da-adocao/>. Acesso 19 nov 2019. 
entre os artigos 39 a 52-D - os capítulos que falam de adoção -, entre os artigos 165 e 170 - da colocação em famílias substitutas - e os artigos 197A e E - referentes ao procedimento de habilitação. Dentre outros motivos, esta falta de um Estatuto próprio, com princípios e procedimentos individualizados ensejou o Projeto de Lei n³94 de 2017 de autoria do Senador Randolfe Rodrigues, que dispõe sobre a criação de um Estatuto da Adoção e que será abordado mais adiante.

Logo no primeiro artigo que trata do procedimento, o ECA estabelece que o processo de adoção é personalíssimo, ou seja, a adoção não pode ser requerida por procuração (artigo $39, \S 2^{\circ}$ do ECA), mas os postulantes devem necessariamente ser representados em juízo por advogados ou pela Defensoria Pública.

Neste sentido, conforme exposto anteriormente os postulantes não necessitam dos amparos de advogados para realizarem o procedimento de habilitação, mas faz-se essencial a representação, a fim de regularizar a capacidade postulatória nos processos de adoção. Em convergência a esse último entendimento encontra-se descrito no artigo 166 do ECA, senão vejamos:

Art. 166. Se os pais forem falecidos, tiverem sido destituídos ou suspensos do poder familiar, ou houverem aderido expressamente ao pedido de colocação em família substituta, este poderá ser formulado diretamente em cartório, em petição assinada pelos próprios requerentes, dispensada a assistência de advogado. (grifo nosso)

Na visão de Guilherme de Souza Nucci ${ }^{64}$ a possibilidade de dispensa do advogado retratada no artigo supracitado se dá apenas nos casos em que não haja contraditório e, portanto, um litígio. No entanto, tal dispensa se faz inconstitucional, entendimento este defendido por José de Farias Tavares $^{65}$ e totalmente pertinente mediante algumas ressalvas. A

${ }^{64}$ NUCCI, Guilherme de Souza. Estatuto da Criança e do Adolescente Comentado: em busca da Constituição Federal das Crianças e dos Adolescentes. $3^{\mathrm{a}}$ ed. Rio de Janeiro: Forense, 2017, p.614 e 615 .

65 TAVARES, José Farias. Comentários ao Estatuto da Criança e do Adolescente. 8 ed. Rio de Janeiro: Forense, 2013. p. 149. 
possibilidade de acesso à justiça garantido pelo artigo $5^{\circ}$ da Carta Magna é de suma importância e de fato não merece ser alterado, no entanto, não faz benéfico principalmente ao menor, mas também aos postulantes, que estes últimos sigam atuando no processo limitados diante da falta de capacidade postulatória, não sendo um impedimento, portanto, que ingressem com a demanda sem representação, entretanto, faz-se necessária a devida regularização do vício, conforme ilustre acórdão do Tribunal de Justiça do Estado de Santa Catarina que reformou sentença que não propiciava aos Requerentes o direito de regularizar o vício da representação:

APELAÇÃO CÍVEL. INFÂNCIA E JUVENTUDE. AÇÃO DE ADOÇÃO. EXTINÇÃO SEM RESOLUÇÃO DO MÉRITO NA ORIGEM. (1) PEDIDO FORMULADO SEM PROCURADOR CONSTITUÍDO. DESNECESSIDADE. EXEGESE DO ART. 166 DO ECA. REGULARIZAÇÃO IGUALMENTE NÃO OPORTUNIZADA. AUSÊNCIA DE CADASTRO NA LISTA DE ADOTANTES. REQUISITO TRANSPONÍVEL. SENTENÇA TERMINATIVA PRECIPITADA. - $\mathrm{O}$ art. 166 do Estatuto da Criança e do Adolescente permite a formulação de pleito de adoção diretamente em cartório, sem a representação por advogado, no que precipitada a extinção do feito por ausência de capacidade postulatória, sobretudo se não oportunizada a regularizacão do vício. Irrelevante para a caracterização do interesse processual, outrossim, a ausência de cadastro dos autores na lista de adotantes, porquanto requisito passível de mitigação a depender do caso concreto. (...) SENTENÇA REFORMADA. RECURSO PROVIDO. (TJ-SC - AC: 20130275676 SC 2013.027567-6 (Acórdão), Relator Des. Henry Petry Junior, Data de Julgamento: 19/06/2013, Quinta Câmara de Direito Civil Julgado, Data de Publicação: 10/07/2013) (grifo nosso)

Há casos também em que o processo de adoção será cumulado com o processo de destituição do poder familiar, que em geral não representam os casos derivados do SNA, visto que as crianças aptas à adoção pelo cadastro em sua maioria já passaram por esse processo e apenas em casos excepcionais, sob forma de medida protetiva, deveriam ser aceitas crianças cujos pais não tiveram esse poder destituído (artigo $4^{\circ}$ do anexo I da Resolução $n^{\circ}$ 289/2019 do CNJ). Nesses casos excepcionais, os candidatos são avisados de todos os riscos gerados pelo não rompimento do vínculo familiar e os processos serão necessariamente cumulados quando se der início ao estágio de convivência. 
Caso o processo de destituição do poder familiar esteja finalizado e seja dado início ao processo de adoção, os pais biológicos não precisam ser citados, sendo necessária apenas a citação do Ministério Público.

Em regra o processo de adoção deve respeitar o prazo máximo de 120 (cento e vinte) dias, prorrogável uma única vez por igual período, mediante a devida fundamentação (artigo 48 do ECA) e, para isso, durante todo o processo existe a presença ativa da equipe multidisciplinar psicólogas e assistentes sociais - que avaliará o desenvolvimento da relação entre postulantes e as crianças e adolescentes.

Ademais, em se tratando de prazos, os processos de adoção dos menores com deficiência crônica terão prioridade na tramitação, cabendo ressaltar que de modo geral todos os processos de adoção já possuem prioridade de tramitação, independentemente da instância em que se encontrem, conforme dispõe o $\S 9^{\circ}$ do artigo 47 do ECA.

No final deste processo, a sentença de adoção que tem natureza constitutiva, passa a gerar um vinculo jurídico de filiação e produz efeitos diante do seu trânsito em julgado, o qual concederá aos novos pais o direito de inscrição de seus respectivos nomes, bem como dos seus ascendentes, no registro de nascimento do menor. Por meio de mandado judicial o registro de nascimento anterior será arquivado e cancelado, não podendo constar nenhuma observação sobre esta alteração (artigo 47 do ECA).

Excepcionalmente, apenas diante de um caso a adoção poderá produzir efeitos ex tunc: no caso de morte de algum postulante durante o procedimento $\left(\$ 7^{\circ}\right.$ do artigo $47 \mathrm{c} / \mathrm{c}$ artigo 49$)$ ou antes de que seja iniciado o procedimento, desde que tenha havido essa manifestação de vontade ainda em vida, caso em que seus efeitos terão força retroativa à data do óbito, configurando a denominada adoção póstuma.

A sentença também confere ao adotado o sobrenome do adotante e, a pedido de qualquer um deles, poderá ser modificado o prenome da criança 
ou do adolescente, mas caso esse pedido seja realizado exclusivamente pelos adotantes, faz-se necessária a oitiva do adotado maior de 12 anos e menor de 12 anos desde que respeitado o seu grau de discernimento ( $\S 6^{\circ}$ do artigo $47 \mathrm{c} / \mathrm{c} \$ \S 1^{\circ}$ e $2^{\circ}$ do artigo 28 do ECA).

Outrossim, todo o processo de adoção ocorre de forma sigilosa e o adotado após completar seus 18 (dezoito) anos de idade tem direito de conhecer sua origem biológica, obtendo acesso irrestrito ao processo, e cabendo também aos menores de 18 (dezoito) anos desde que assegurada orientação e assistência jurídica e psicológica (artigo 48 do ECA).

Uma diferenciação neste processo, bem como em todos os processos regulamentados no ECA, é a de que os prazos são contados em dias corridos - excluindo o dia do começo e incluído o dia do vencimento - ao invés de dias úteis como estabelece o Código de Processo Civil. Esse procedimento especial prevalece sobre o procedimento comum e também veda o prazo em dobro normalmente conferido ao Ministério Público e à Fazenda Pública, conforme regulamenta o $§ 2^{\circ}$ do artigo 152 do ECA.

Após a prolação da sentença iniciam-se os prazos recursais, nos quais as oposições independem de preparo e devem ocorrer no prazo de 10 (dez) dias, inclusive para o Parquet, ressalvando os embargos de declaração que devem ser opostos em 5 (cinco) dias.

Qualquer um dos recursos relativos à adoção terá preferência e dispensará o trabalho de um revisor, sendo que antes de ocorrer a remessa à segunda instância, nos casos de apelação e agravo de instrumento, necessariamente, a autoridade judiciária deverá proferir despacho fundamentado mantendo ou reformando a decisão recorrida, no prazo de 5 (cinco) dias.

No caso específico da adoção, o artigo 199-A, enfatiza que a sentença produz efeitos desde logo, mesmo que sujeita à apelação, ressaltando que este recurso deverá ser recebido apenas em seu efeito 
devolutivo, salvo nos casos de adoção internacional ou nos que houver risco de dano irreparável ou de difícil reparação para o adotando.

Por fim, todos os recursos derivados de um processo de adoção terão absoluta prioridade de processamento em segunda instância (artigo 199-C), devendo ocorrer imediata distribuição e colocação em mesa para o seu julgamento que se dará sem revisão e com um parecer proferido em caráter urgente pelo Ministério Público.

Infelizmente, em geral, o Ministério Público ou a Defensoria Pública - mesmo nos casos em que os pais biológicos sejam revéis - têm o costume de recorrer das sentenças que proferem a adoção, entendendo erroneamente que estão, assim, agindo de forma a atender ao melhor interesse das crianças e adolescentes brasileiros, mas na realidade estão dificultando e atrasando ainda mais um processo que em muitos Estados do nosso país já é extremamente lento e, consequentemente, angustiante para todas as partes envolvidas. 


\section{NUÂNCES DAS ADOÇÕES INTERNACIONAIS}

No Brasil, a adoção internacional passou a ter norma específica a partir do Código de Menores de 1979 que sintetizou a adoção por estrangeiros não residentes a condição de adoção simples e somente nos casos em que o menor estivesse em condições praticamente de abandono. ${ }^{66}$

Infelizmente, a adoção internacional já foi realizada sem muita supervisão estatal, via escritura e em muitos casos, negociava-se com a mãe biológica o "consentimento" em troca de algum auxílio financeiro, fomentando a prática de venda de crianças ou até mesmo o seu tráfico, realidade resultante de um país no qual a miséria até os dias atuais, em pleno século XXI, continua existindo.

Finalmente, por meio da Constituição Federal de 1988, em seu artigo 227 , $\S 5^{\circ}$ puderam ser vislumbrados novos horizontes para o instituto, diante do estabelecimento de que uma lei específica deveria passar a tratar do tema, determinando que houvesse desde já a assistência do Poder Público nesse processo:

Art. 227. É dever da família, da sociedade e do Estado assegurar à criança, ao adolescente e ao jovem, com absoluta prioridade, o direito à vida, à saúde, à alimentação, à educação, ao lazer, à profisssionalização, à cultura, à dignidade, ao respeito, à liberdade e à convivência familiar e comunitária, além de colocá-los a salvo de toda forma de negligência, discriminação, exploração, violência, crueldade e opressão.

\section{(...)}

$\S 5^{\circ}$ A adoção será assistida pelo Poder Público, na forma da lei, que estabelecerá casos e condicões de sua efetivacãa por parte de estrangeiros. (grifo nosso)

Nesta crescente, o Estatuto da Criança e do Adolescente surgiu em 1990 como a fonte interna de natureza protecionista e de interesse público, no qual passou a tratar a adoção como medida excepcional, quem dirá a adoção internacional que passou a ter um teor de excepcionalidade maior ainda, visto que somente pode ser realizada quando esgotadas todas as 
possibilidades de adoções por pretendentes com residência no território nacional:

Art. 31. A colocacão em família substituta estrangeira constitui medida excepcional, somente admissível na modalidade de adoção. (grifou nosso)

Além das normativas apresentadas, a regulamentação da adoção internacional também teve como fonte a Convenção Interamericana sobre os Conflitos em Matéria de Adoção de Menores (promulgada pela lei $\mathrm{n}^{\circ}$ 2.429/97) e a Convenção de Haia sobre Cooperação Internacional e Proteção de Crianças e Adolescentes em Matéria de Adoção Internacional (promulgada pelo Decreto $\mathrm{n}^{\circ} 3.087 / 99$ ), que influenciaram diretamente as alterações posteriores ao texto do ECA.

Diante dos pontos até então tratados, faz-se importante ressaltar que a adoção internacional não corresponde diretamente com a nacionalidade do candidato. Sendo assim, um estrangeiro que tenha estabelecido residência fixa ou domicílio no Brasil é enquadrado dentro da adoção nacional, por outro lado, um brasileiro que tenha estabelecido residência ou domicílio fora do Brasil, se quiser adotar uma criança brasileira, será enquadrado no procedimento de adoção internacional.

Ademais, para configurar a adoção internacional é necessário que além de o pretendente possuir residência habitual fora do Brasil, essa residência precisa residir em um país-parte da Convenção de Haia de Adoção Internacional de 1993:

Estatuto da Criança e do Adolescente

Art. 51. Considera-se adoção internacional aquela na qual o pretendente possui residência habitual em país-parte da Convenção de Haia, de 29 de maio de 1993, Relativa à Proteção das Crianças e à Cooperação em Matéria de Adoção Internacional, promulgada pelo Decreto ${ }^{\circ} 3.087$, de 21 junho de 1999, e deseja adotar criança em outro país-parte da Convenção.

Portanto, a adoção internacional encontra-se ancorada em dois princípios: o da subsidiariedade e o do melhor interesse da criança. $\mathrm{O}$ primeiro princípio encontra respaldo nos artigos $31,50, \S 10^{\circ} \mathrm{c} / \mathrm{c} 51$, II do ECA que apontam essa medida como excepcional e o segundo princípio é 
retratado mediante o artigo 43 do ECA que determina que a adoção será deferida quando apresentar reais vantagens para o adotando e estiver fundada em motivos legítimos.

Desta forma, visando atender prioritariamente ao melhor interesse da criança, faz-se necessário que o princípio da subsidiariedade seja aplicado com cautela, afinal, seu cumprimento sob qualquer circunstância ignora o risco de que as necessidades prementes de crianças e adolescentes não sejam atendidas:

"Por isso, não se deve esperar que as dificuldades brasileiras sejam superadas, mesmo que tenhamos que reconhecer a incapacidade do governo; não se pode ignorar o fato de que a adoção por estrangeiro constitui uma pequena solução para o problema do abandono",67.

Entretanto, se a adoção de crianças menores de 10 (dez) anos no Brasil já faz com que os pretendentes enfrentem filas demoradas, quem dirá os adotantes internacionais que estão em último lugar e diariamente atingem colocações piores diante do cadastramento de novas família residentes no Brasil e que tem preferência, em razão do princípio da subsidiariedade. Desta forma, são esses candidatos, em sua maioria, os responsáveis por adotar grupos de irmãos ou crianças com algum tipo de deficiência, ou seja, crianças e, principalmente, adolescentes que são diariamente rejeitados pelos pretendentes brasileiros, conforme destaca Luiz Paulo Aoki ${ }^{68}$ :

"Na prática, contudo, a excepcionalidade pouco atinge os casos de adoção internacional, resguardados em sua maioria para aquelas crianças ou alguns adolescentes já preteridos há algum tempo pelos casais nacionais, que ainda guardam o preconceito, em sua maioria, de aceitar apenas recém-nascidos, e, normalmente, de pais conhecidos, além de outros resquícios de preconceitos de todos conhecidos."

67 TIBURCIO, Carmen; BARROSO, Luis Roberto. O direito internacional contemporâneo. 4 ed. Rio de Janeiro: Renovar, 2000. p. 10

68 AOKI, Luiz Paulo Santos. Comentários ao art. 31 do ECA. In: CCURY, Munir (Coord.). Estatuto da Criança e do adolescente comentado - comentários jurídicos e sociais. 7 ed. São Paulo: Malheiros, 2005. p. 239. 


\subsection{DO PROCEDIMENTO}

Todas as regras - dentre elas os requisitos objetivos e subjetivos até aqui apresentadas quanto aos pretendentes à adoção nacional são aplicadas diretamente aos pretendentes à adoção internacional - ressaltando que esta última apenas se perfaz apenas com pretendentes residentes nos países-partes da Convenção de Haia. No entanto, apesar desta semelhança, o trâmite processual destes tipos de adoção é distinto e, em relação a este procedimento, cabe destacar que o Brasil tem competência exclusiva nos processos de adoção internacional de crianças e adolescentes brasileiras.

Diante do caráter subsidiário da adoção internacional, existe ainda mais uma hierarquia nesse sistema, visto que deve também ser dada preferência na fila para os brasileiros residentes no exterior, conforme determina o $2^{\circ}$ do inciso III do artigo 51 do ECA.

Sendo assim, a partir do momento que ocorre a decisão pela adoção internacional, os pretendentes devem se encaminhar à Autoridade Central em matéria de adoção internacional do país de acolhida (aquele em que está compreendido a residência habitual dos pretendentes) e será formulado o pedido de adoção (artigo 52, I do ECA).

Caso a Autoridade Central do país de acolhida entenda que o pretendente se encontra apto para adotar, será emitido um relatório que contenha informações sobre a sua identidade, sua capacidade jurídica, sua situação pessoal, familiar e médica, seu meio social, os motivos que o animam a realizar o cadastro e a sua aptidão para assumir essa função.

Este relatório será instruído da documentação necessária e deverá ser enviado junto do estudo social realizado no país de acolhida, bem como da cópia da legislação pertinente, acompanhada da respectiva prova de vigência, - devendo todos os documentos estarem autenticados e devidamente traduzidos por tradutor juramentado - à Autoridade Central 
Estadual, com cópia para a Autoridade Central Federal Brasileira (incisos II, III e IV do artigo 52 do ECA).

A Autoridade Central Estadual poderá fazer exigências e solicitar complementação do estudo psicossocial, estudará a compatibilidade da lei do país de acolhida com a lei nacional e, após esse trâmite, expedirá laudo de habilitação à adoção internacional, que terá validade de 1 (um) ano. Com a posse desse laudo e depois de ouvido o Ministério Público ${ }^{69}$, os pretendentes poderão ser cadastrados pelas Comissões Estaduais Judiciárias de Adoção (CEJAS/CEJAIS) do Tribunal de Justiça no SNA, passando a integrar um cadastro único junto aos candidatos brasileiros e não mais um cadastro em separado, conforme ocorria na vigência do antigo CNA.

Portanto, ao contemplar a possibilidade de a adoção internacional ser condicionada a um estudo prévio de uma Comissão Estadual Judiciária de Adoção - conforme determinado pelo revogado artigo 52 e, atualmente, pelos incisos VI e VII do atual artigo 52 do ECA - em verdade, o Estatuto antecipou o que viria a ser determinado pela Convenção de Haia sobre Adoção Internacional de 1993, a qual prevê de forma expressa em seus artigos $6^{\circ}$ ao 13 , a criação de um sistema de autoridades centrais, encarregados de exercer maior controle sobre as adoções internacionais em cada Estado de origem.

Cabe ressaltar que tal função é desempenhada por esses órgãos, dado que foi conferida competência aos CEJA e CEJAI para exercerem essas funções de Autoridade Central quando aprovado por unanimidade no III Encontro Nacional das CEJAs, realizado em São Paulo, em abril de $1996^{70}$

O CEJA (Comissão Estadual Judiciária de Adoção) ou CEJAI (Comissão Estadual Judiciária de Adoção Internacional) são órgãos judicantes que tem, atualmente, o objetivo de reduzir as possibilidades de tráficos internacionais de crianças para fins diversos: prostituição infantil, 
tráfico de órgãos ou até mesmo o da adoção irregular. Neste sentido cabe ressaltar que a prática de adoção internacional, até mesmo por meios regularizados, quando culmina em finalidade econômica, é terminantemente proibida conforme a Convenção de Haia, a alínea "d"do artigo 21 da Convenção sobre os Direitos das Crianças e pelo artigo 239 do ECA:

Art. 239. Promover ou auxiliar a efetivação de ato destinado ao envio de criança ou adolescente para o exterior com inobservância das formalidades legais ou com o fito de obter lucro:

Pena - reclusão de quatro a seis anos, e multa.

Parágrafo único. Se há emprego de violência, grave ameaça ou fraude:

Pena - reclusão, de 6 (seis) a 8 (oito) anos, além da pena correspondente à violência.

Desta forma, diante do cumprimento da enorme lista de exigências, do posterior cadastramento no SNA e após terem sido realizadas todas as tentativas de vinculação das crianças e adolescentes aos candidatos residentes no Brasil, a Resolução ${ }^{\circ} 289$ dispõe que o juízo competente tem o prazo máximo de 5 (cinco) dias para iniciar as buscas internacionais, dando a devida ciência à CEJA/CEJAI do respectivo tribunal.

No momento em que for realizada essa vinculação ao candidato estrangeiro, este deve manifestar sua anuência da mesma forma que ocorre com os candidatos à adoção nacional, no entanto, a Resolução $n^{\circ} 289$ de 2019 - referente ao novo SNA - não regulamentou esse prazo, de forma que não se faz prudente a utilização do prazo de até 5 (cinco) dias disposto aos candidatos residentes no Brasil e, portanto, ocasiona em mais uma lacuna a ser sanada mediante o bom senso do magistrado em questão,

Ademais, nos casos da vinculação com um adolescente, para que a adoção possa ser consolidada, faz-se essencial a consulta ao menor, por meios adequados ao seu estágio de desenvolvimento, a fim de que possa consentir com a mudança (inciso III do artigo 51 do ECA), visto que além da mudança na vida desses menores mediante o ingresso em nova família, os mesmos passarão a viver em meio a uma nova cultura. 
Portanto, é a partir desta vinculação que os candidatos devem vir ao Brasil, visto que o estágio de convivência deve ocorrer em território nacional e nesses casos o estágio tem prazo mínimo de 30 (trinta) dias e prazo máximo de 45 (quarenta e cinco) dias para ser cumprido, prorrogáveis por igual período por uma única vez e necessariamente mediante decisão judicial fundamentada (artigo $46, \S 3^{\circ}$ ).

Posteriormente, no final deste prazo de convivência, será elaborado laudo fundamentado pela equipe técnica da respectiva Vara competente que apresentarão relatório minucioso acerca da convivência do deferimento da medida (artigo $46, \S \S 3^{\circ} \mathrm{A}$ e $4^{\circ}$ do ECA).

Diante do laudo positivo da equipe técnica, o processo segue os trâmites iguais ao de uma adoção nacional, cabendo salientar apenas uma exceção em relação à produção de efeitos da sentença, visto que a criança ou adolescente adotados não poderão deixar o país antes do trânsito em julgado da mesma (artigo 52, $\S 8^{\circ}$ do ECA).

Desta forma, assim que transitar em julgado a sentença, a autoridade judiciária determinará a expedição de alvará com autorização de viagem e autorizará a confecção de passaporte ao menor, devendo constar, obrigatoriamente, as características físicas do filho adotado (como idade, sexo, cor, eventuais sinais ou traços peculiares), assim como foto recente e a aposição da impressão digital do seu polegar direito.

Por fim, cabe salientar que somente será possível o credenciamento de organismos internacionais encarregados de intermediar a mediação dessas adoções internacionais, se forem oriundos de países-parte da Convenção de Haia de 1993 e que estejam devidamente credenciados nas Autoridades Centrais do país de acolhida do adotando. Ademais, o ECA em seu artigo 51, $\S 3^{\circ}$ exige que o organismo possua a devida integridade moral, competência profissional, experiência e responsabilidade em atuar com adoção, bem como possuírem padrões éticos e cumprirem os requisitos 
exigidos pelo ordenamento jurídico brasileiro e pelas normas estabelecidas pela Autoridade Central Federal Brasileira.

Além disso, esses organismos deverão ainda não perseguir fins lucrativos, conforme exposto anteriormente, permanecendo em constante fiscalização das autoridades competentes do país em que estejam sediados e nos de acolhida e, finalmente, devem enviar relatórios pós-adotivos semestralmente para a Autoridade Central Estadual (com cópia para a Autoridade Central Federal Brasileira) pelo período mínimo de 2 (dois) anos.

Por derradeiro, caso o credenciamento com validade de 1 (um) ano não tenha sido suficiente para que ocorra a vinculação, é possível a sua renovação mediante requerimento protocolado na Autoridade Central Federal Brasileira nos últimos 60 (sessenta) dias anteriores ao término do respectivo prazo de validade (artigo 52, $\S 7^{\circ}$ do ECA). 


\section{NOVOS OLHARES E NOVAS PRÁTICAS}

Dificilmente um cidadão brasileiro cresceu sem ouvir algum comentário sobre o instituto da adoção, seja porque conhecem alguma pessoa que passou pelo processo, seja por via do preconceito/culto extremo aos laços biológicos, seja porque conheceram candidatos que reclamavam da burocracia do processo ou pelo tempo de espera e, até mesmo, por terem escutado informações não muito prazerosas sobre os abrigos públicos.

O Estatuto da Criança e do Adolescente, apesar de ser uma norma jurídica reconhecida internacionalmente e referência na proteção aos direitos dos menores, apresenta um distanciamento entre a teoria e a prática no quesito da adoção, principalmente advindos da Lei $n^{\circ}$ 12.010/2009, que tem sido aplicada de forma extremamente equivocada e perniciosa, baseada numa espécie de reverência quanto à manutenção do menor em sua família biológica, ocasionando buscas e burocratizações desmedidas em detrimento ao superior interesse dos acolhidos.

Não pode ser mais aceitável que uma criança perca qualquer pedaço de sua infância ou adolescência em razão de atitudes irresponsáveis ou pela falta dessas atitudes por parte dos adultos. A demora excessiva na definição da situação familiar aos abrigados apresenta uma enorme violação à Doutrina da Proteção Integral e à Prioridade Absoluta, presentes expressamente nos tratados internacionais dos quais o Brasil é signatário.

Neste sentido, o juiz Sérgio Kreuz, titular da Vara de Infância e Juventude de Cascavel no Estado do Paraná, pontua brilhantemente sobre o perigo da vulnerabilidade afetiva ao qual submetemos esses menores:

"O ECA repete mais de vinte vezes a necessidade de esgotar os meios de manter a criança na família natural. Mas o que isso significa? Quando posso dizer que em relação a um pai drogado, que não aceita tratamento, foram esgotados os meios de manter a criança na família de origem? E de daqui a quatro anos, quando a criança já estiver em outra família, o pai se recuperar? Não vamos resolver essa questão com mais leis, com mais prazos. 
Vamos resolver na medida que as varas da Infância e da Juventude efetivamente forem prioridades dos tribunais de justiça, do $\mathrm{CNJ}$, e as redes de proteção à criança estiverem efetivamente implantadas no município"71.

Nesse contexto, o IBDFAM - Instituto Brasileiro de Direito de Família - em seu XI Congresso Brasileiro de Direito das Famílias e Sucessões, no ano de 2017, lançou um projeto chamado "Crianças invisíveis" que possuía dentre um de seus objetivos a ratificação do Projeto de Lei do Estatuto da Adoção.

O referido projeto se concretizou por meio do Projeto de Lei do Senado n 394 de 2017 que dispunha sobre o Estatuto da Adoção, um projeto derivado de amplo estudo e debate de especialistas no tema, dentre elas a jurista Maria Berenice Dias e a advogada e presidente da Comissão Nacional de Adoção do IBDFAM, Silvana do Monte Moreira, e tinha como objetivo retirar as disposições sobre adoção de dentro do ECA, a fim de lhe garantir maior atenção via estatuto próprio, lastreado nos mesmos princípios.

Assim, visando solucionar o problema do esquecimento de milhares de crianças e adolescentes em abrigos - cidadãos estes invisíveis e sem voz no país, resultado de uma espera infindável pela desconstituição do poder familiar ou busca pela família extensa - e orientar um Poder Judiciário que ainda permanece confundindo o conceito de família como filiação biológica, quando hoje a prevalência é a da filiação socioafetiva, foi criado o referido projeto.

A famosa frase "a conta da adoção não fecha" não pode ser analisada superficialmente, já que sua incongruência é latente, dado que de um lado existem milhares de famílias ansiosas para cuidar afetuosamente de um filho, de outro lado existem milhares crianças abandonadas e destinadas a perder sua infância/adolescência em esperas extremamente prejudiciais, 
pagando um valor alto e imensurável ao serem consideradas aptas à adoção quando já possuem idade avançada.

Apesar de o novo SNA conter uma opção em seu website que deveria demonstrar as estatísticas acima mencionadas, infelizmente, a plataforma não está funcionando regularmente ${ }^{72}$. Sendo assim, a fim de ilustrar a realidade supracitada, o último dado oficial sobre o assunto foi disposto no website do antigo CNA no dia 06.08.2019 e retrata que existia um total de 9.366 crianças e adolescentes ${ }^{73}$ aptos à adoção cadastrados naquele sistema em todo o Brasil, bem como $46.190^{74}$ pretendentes aptos à adoção nacional e $233^{75}$ aptos à adoção internacional.

Portanto, é notório que esse cálculo possui problemas e visando evitar que os adolescentes permaneçam completando a maioridade acolhidos em abrigos públicos, sem nenhuma perspectiva de constituição de família, o projeto de lei estabeleceu períodos máximos. Dentre eles, para as tentativas de reinserção familiar ou busca por famílias extensas, foi estabelecido o prazo de 30 (trinta) dias, bem como determinou que encontrando-se a criança ou o adolescente acolhido há mais de 1 (um) ano, qualquer pessoa poderá propor a ação de perda, suspensão ou extinção da parentalidade - ressalta-se que não utilizam aqui o termo poder familiar na forma de legitimados extraordinários.

Além disso, os candidatos a adoção passariam a figurar com postura ativa de fiscalização do cumprimento das normas, na condição de assistente

72 Website do SNA. Disponível em <https://www.cnj.jus.br/sna/estatisticas.jsp>. Acesso 19 nov 2019. _cna_cnj_20190806.pdf>. Acesso 19 nov 2019.

$74 \quad$ Disponível em <http://www.crianca.mppr.mp.br/arquivos/File/noticias/adocao/relatorio_de_pretendentes_cadastr ados_nacional_cna_cnj_20190806.pdf>. Aceso 19 nov 2019.

75 Disponível em <http://www.crianca.mppr.mp.br/arquivos/File/noticias/adocao/relatorio_de_pretendentes_cadastr ados_internac_cna_cnj_20190806.pdf>. Acesso 19 nov 2019 
simples (artigo 119 do CPC) para intervir, em qualquer ação, quando verificada a ocorrência de inércia ou injustificável demora.

Em seus artigos 27 ao 31, estabeleceu o acolhimento familiar como preferencial em detrimento ao acolhimentos institucional, tendo estabelecido o último como medida excepcional. Ademais estabeleceu o prazo para o acolhimento familiar em 1 (um) ano, passível de prorrogação apenas nos casos de impossibilidade de reinserção na família de origem ou em família adotiva; a preferência do programa para grupos de irmãos, crianças acima dos oito anos ou com algum tipo de doença e também a preferência para adoção pelas famílias acolhedoras ou padrinhos que já estavam em contato com o menor, independentemente da necessidade de realização de habilitação e cadastramento.

$\mathrm{O}$ projeto de lei, além de fixar prazos antes inexistentes e que ficavam à mercê do respectivo juízo - como por exemplo, a fixação do prazo de 30 (trinta) dias para a apresentação do laudo do estudo psicossocial nas ações de adoção, dentre outros anteriormente mencionado - também trouxe mudanças decorrentes de um sistema judiciário em geral lento, dentre elas a de não ser mais necessário aguardar o trânsito em julgado da sentença desconstitutiva da parentalidade para a concessão da guarda provisória para fins de adoção.

Portanto, o referido projeto era cristalino quanto ao seu propósito: eliminar entraves burocráticos e emprestar celeridade aos processos de desconstituição do poder familiar, trazendo à realidade o que era melhor, primeiramente, para a criança ou o adolescente, antes de buscar o que era melhor para qualquer um dos adultos envolvidos, utilizando-se da lógica de que deve ser buscada uma família saudável a uma criança que foi afastada de sua família natural, assegurando-lhes o direito à convivência familiar, que lhes é constitucionalmente previsto, com prioridade absoluta.

Após a apresentação ao Senado Federal, em 18/10/2017, o projeto de lei foi remetido à Comissão de Direito Humanos e Legislação que realizou 
três audiências públicas para debater sobre o tema, tendo sido apresentado e votado o parecer e, posteriormente, o projeto foi encaminhado para a Comissão de Constituição, Justiça e Cidadania, local em que atualmente se encontra acompanhado do parecer da relatora que está pendente de $\operatorname{votação~}^{76}$.

O parecer da Comissão de Direito Humanos e Legislação se deu pela prejudicialidade do projeto e consequente arquivamento e o parecer da relatora, senadora Rose de Freitas, da Comissão de Constituição, Justiça e Cidadania, votou pela rejeição do projeto, ambos embasados no entendimento de que a Lei $\mathrm{n}^{\circ} 13.509$ de 22 de novembro de 2017 que tratava precisamente sobre adoção já tinha sido aprovada e apresentava benefício maior por manter toda a matéria legal sobre adoção integralmente no corpo do ECA.

Felizmente, apesar da rejeição de projeto de alta valia para o tema, a adoção no Brasil, atualmente, conta com outros mecanismos capazes de tentar minimizar o sofrimento e a espera de crianças e adolescente. Dentre eles, cabe destacar o aplicativo de adoção tardia denominado A.DOT ${ }^{77}$ que se trata de uma plataforma de aplicativo para celular, criada em parceria do Tribunal de Justiça do Paraná, por meio da Corregedoria-Geral da Justiça do Paraná e do Conselho de Supervisão dos Juízos da Infância e da Juventude (CONSIJ-PR), do Grupo de Apoio Adoção Consciente (GAACO) e da Agência Blablu.ag, cuja proposta é a de conectar crianças e adolescentes em condições de adoção com pretendentes habilitados no cadastro nacional, atualmente o SNA.

A realidade por trás desse projeto é o de que todos os pais necessariamente idealizam seus filhos, sendo eles biológicos ou adotivos, e não há nada mais natural. Não necessariamente o filho nascerá com as

76 Andamentos do Projeto de Lei n 394 de 2017 do Senado Federal. Disponível em <https://www25.senado.leg.br/web/atividade/materias/-/materia/131275>. Acesso 14 nov 2019 77 Site sobre o aplicativo A.DOT. Disponível em < https://adot.org.br/>. Acesso 14 nov 2019 
características físicas ou comportamentais desejadas, mas há um elo que conecta essa relação passível de superar qualquer detalhe adverso ao esperado: $\mathrm{o}$ amor.

Aliado a isto, muitas Varas da Infância descumprem o artigo 50, parágrafo $4^{\circ}$ do ECA e não possibilitam o contato dos candidatos com as crianças e adolescentes abrigadas, fazendo com que as mesmas sejam conhecidas simplesmente por um número. Ora, não é factível a existência de um olhar ingênuo e romantizado que ignore o fato de ser mais difícil se apaixonar por "João, pardo, saudável, 8 anos" do que por "João, 8 anos, amante de futebol, menino do sorriso frouxo e que sonha em se tornar professor".

Conforme retrata Maria Berenice: "Eu não conheço ninguém que tenha adotado criança com algum tipo de dificuldade ou grupos de irmãos, se simplesmente não tiver se apaixonado pelo adotado"78 e o aplicativo possibilita justamente isso, que os pais habilitados possam realizar um login e ficar navegando entre os vídeos feitos pelas próprias crianças e adolescentes que contam um pouco de si.

Outro projeto no mesmo âmbito do aplicativo A.DOT é o "Missão Diversão", criado por Marcella Cesa Bertoluci, uma jovem de apenas 18 (dezoito) anos que instigada por um projeto escolar decidiu reunir diversas crianças e adolescentes que viviam em abrigos na cidade de Porto Alegre/RS e os adultos interessados em adotar, de forma a impulsionar a adoção tardia:

“Com supervisão de técnicos e magistrados do $2^{\circ}$ Juizado da Infância e da Juventude, a reunião aconteceu no Colégio Farroupilha, local onde a jovem estudou, e contou com a participação de 30 crianças órfãs e 24 adultos que já cumpriram requisitos legais e estão aptos a concretizarem a adoção. No encontro, foram registradas duas manifestações de interesse de adoção.,"79

78 Revista n ${ }^{\circ}$ 31, Crianças Invisíveis do IBDAM. Op. cit., p. 6.

79 Matéria do site IBDFAM. Disponível em <http://www.ibdfam.org.br/noticias/6893/Jovem+cria+projeto+visando+ado\%C3\%A7\%C3\%A3o +tardia+de+crian\%C3\%A7as+em+Porto+Alegre>. Acesso 14 nov 2019. 
Sendo assim, diante da luta diária que essas crianças enfrentam, o país não pode permanecer sem tomar atitudes acerca dos menores acolhidos, o país precisa dar voz a essas crianças. O Brasil precisa acolher também essas famílias candidatas à adoção, porque assim como qualquer família biológica, elas não nasceram prontas para desempenhar a tarefa parental e, na realidade, dificilmente estarão prontas para enfrentar todos os desafios.

A parentalidade é uma busca constante por aprendizado, visto que por mais que os pais tentem projetar, organizar, estabelecer prazos e metas, há circunstâncias na geração e desenvolvimento de um filho que fogem à determinação humana, não podendo comandar ao seu bel-prazer esse processo.

O psicólogo Luiz Schettini Filho trata brilhantemente sobre o tema de responsabilização dos filhos em atender às expectativas de pais e genitores:

\begin{abstract}
"Os filhos nunca serão objeto de total satisfacão dos pais. Aliás, eles não vieram com essa finalidade. E assim será de geração em geração. Se entendermos a existência dos filhos como parte de um desejo e de uma consequiência da biologia humana não os veremos como uma propriedade privada sobre a qual temos direitos pessoais. Não se tem direitos sobre pessoas; temos deveres, por estarmos em um estado de relação no qual uns dependem dos outros, conforme determinadas circunstâncias, no que diz respeito à idade ou a condições relativas a seu grau de autonomia. ${ }^{80, " ~(g r i f o ~ n o s s o) ~}$
\end{abstract}

Nesse viés de amparar famílias recém constituídas pelo vínculo da adoção ou ainda em estágio de convivência foi criado, na cidade do Rio de Janeiro, o projeto "Pós-Natal da Adoção" que se trata de reuniões com o objetivo de atuar preventivamente (combatendo o temido fantasma da devolução), de forma informativa (transmitindo experiências) e construtiva (dos laços parentais na forma do exercício da parentalidade responsável).

O projeto foi criado no final de 2013 e trata de uma concepção de pós-natal onde os filhos podem nascer com 0 até 17 anos, buscando trazer

80 FILHO, Luiz Schettini. Pedagogia da adoção: criando e educando filhos adotivos. $3^{\mathrm{a}}$ ed. Curitiba: Juruá, 2017. p, 15. 
um amparo aos pais durante o prazo previsto de 12 meses após a constituição daquela família, mas nada impede que os mesmos permaneçam por mais ou menos tempo, visto que a participação ocorre voluntariamente.

Tal prática foi indicada ao prêmio Innovare na categoria advocacia e permaneceu entre as finalistas do concurso, sendo possível concluir que se trata de uma ferramenta que apenas tende a acrescentar pontos positivos na vida de tantas famílias constituídas por adoção e, portanto, deveria ser expandida a todos os estados do país, trazendo uma alternativa para aliviar o fluxo das consultas ao judiciário da infância, incluindo as assoberbadas equipes técnicas das varas da infância e juventude, dirimindo as dúvidas jurídicas e questões psicológicas da consecução dessa parentalidade. 


\section{CONCLUSÃO}

Diante da mudança de paradigma que o Direito das Famílias enfrentou, baseado no princípio da Dignidade da Pessoa Humana, na qual a família passou a ser estruturada principalmente em vínculos de afeto, amor e igualdade, finalmente pôde ser compreendido que a família não é uma base natural, e sim cultural da sociedade, não se constituindo apenas por um homem, mulher e seus filhos, mas na realidade por uma edificação psíquica, na qual cada um de seus membros ocupa uma função estabelecida socialmente, sem que haja necessidade da existência de vínculo biológico ${ }^{81}$.

Neste sentido, todo filho, independente da sua origem, precisa ser adotado, porque adotar significa escolher e em nada adianta ter vínculos biológicos com qualquer pessoa se aquela criança ou adolescente realmente não foi escolhido após o seu nascimento. Essa afirmação de escolha em diferentes momentos significa sentir no âmago a sensação de ser amado, de pertencer a um grupo, sensações estas que se traduzem ao longo da vida em segurança. $\mathrm{O}$ Brasil precisa trazer segurança aos seus pequenos e o custo disso não pode ser maior do que eles podem pagar.

Sendo assim, o debate sobre o tema da adoção deveria ter adquirido um caráter mais usual, dado que é um instituto antigo na sociedade brasileira conhecido desde a época colonial -, que retrata justamente a prevalência do vínculo afetivo às questões biológicas e que possui diversos pontos a serem melhorados, principalmente quanto a sua aplicabilidade.

Durante o presente estudo fez-se possível constatar uma divergência de opiniões de especialistas sobre o tema, o que transpareceu mediante a existência de diferentes caminhos de atuação, como por exemplo, Silvana do Monte Moreira que defende que o "sangue sem afeto e sem cuidado não gera famílias. Essa inversão de prioridade precisa acabar. São necessárias

\footnotetext{
${ }^{81}$ PEREIRA, Rodrigo da Cunha. Direito de Família e Psicanálise. São Paulo: Imago, 2003. p. 219-228.
} 
medidas que visem responsabilizar a ineficácia do Judiciário" ${ }^{22}$, entretanto, a juíza auxiliar do Conselho Nacional de Justica (CNJ) do ano de 2017, Sandra Silvestre, defendia que os trâmites de retirada de uma criança da família de origem não poderiam ser um procedimento rápido, o que questiona em parte essa caracterização de ineficácia do judiciário: "Vidas estão em jogo. E, muitas vezes, vidas que são consequência de um processo antigo de exclusão social, que leva as pessoas à marginalidade, ao uso e vício de substâncias entorpecentes, à pobreza extrema, dentre outras circunstâncias que caracterizam a miséria humana em um país como o nosso" $"$.

Essas divergências de entendimento quanto ao método prático de atuação dos profissionais envolvidos no processo de adoção não devem desembocar na busca pela culpabilização de um único segmento pelas falhas desse sistema, visto que esse olhar minimalista não proporciona uma solução adequada para a resolução do problema que tantas crianças e adolescentes brasileiros abrigados enfrentam: não conseguirem ser inseridos no seio de uma família.

Por outro lado, os candidatos à adoção também não podem ser responsabilizados pela idealização de um filho, prática está que é inerente ao imaginário de qualquer pai ou mãe, e, consequentemente, pelo baixo número de adoções tardias comparado com a adoção de recém-nascidos e crianças mais novas, ainda mais em se tratando da realidade de muitos juízos que impedem o contato desses candidatos com as crianças e adolescentes dos abrigos e, consequentemente, a possibilidade da constituição desses vínculos.

Obviamente, o Poder Judiciário não detém o poder de obrigar alguém a amar ou preferir um grupo específico de crianças, até mesmo porque esta

\footnotetext{
82 Revista $\mathrm{n}^{\circ}$ 31, Crianças Invisíveis do IBDFAM. Disponível em <http://www.ibdfam.org.br/publicacoes/leitor/31.>. Acesso em 14 nov 2019, p. 8 e 9.

83 Revista $\mathrm{n}^{\circ}$ 31, Crianças Invisíveis do IBDFAM. Disponível em <http://www.ibdfam.org.br/publicacoes/leitor/31.>. Acesso em 14 nov 2019, p. 9.
} 
seria uma prática diretamente violadora do melhor interesse da criança que deve ser acolhida por amor e não por pressão.

Então, diante dessa "conta que não fecha", surgem alguns questionamentos: a preferência por crianças pequenas seria o único motivo gerador do acolhimento das crianças e, principalmente, dos adolescentes até atingirem a maioridade? Por qual motivo os abrigos possuem crianças institucionalizadas sem estarem aptas à adoção e por quanto tempo essas crianças normalmente permanecem acolhidas?

Essas duas perguntas direcionam a uma mesma resposta: muitas crianças chegam aos abrigos ainda pequenas, mas a demora nos trâmites do processo de reinserção no núcleo familiar biológico ou na destituição do poder familiar, faz com que elas permaneçam anos da sua infância acolhidas e quando finalmente se tornam aptas à adoção, já estão mais velhas e se encaixam no difícil perfil de adoção tardia.

Diante da experiência adquirida com o instituto da adoção ao longo dos anos, surge outro questionamento: a tendência de buscar manter a criança em sua família biológica permanece sendo a melhor opção a ser oferecida aos menores acolhidos? Frente ao presente estudo constata-se que essa espera é ilegítima, sendo desumana a imposição aos pequenos cidadãos da perda de anos de sua infância, estágio primordial no desenvolvimento humano, na espera de que os adultos da sua família biológica finalmente os aceitem ou estejam preparados para recebê-los. Ademais, em se tratando das famílias extensas, não existem fundamentos para justificar a manutenção junto a um parente distante da realidade do menor, uma pessoa totalmente estranha à criança, e que em nenhum aspecto benéfico se difere de um candidato devidamente habilitado, mas apenas de forma negativa, visto que esta pessoa não escolheu espontaneamente o exercício da parentalidade e, consequentemente, não enfrentou uma preparação adequada para essa função. 
Outrossim, logo após o enfrentamento dessas barreiras relacionadas à família biológica, depara-se com um outro empecilho: a lentidão no processamento das ações de adoção. Cabe pontuar que essa realidade não se aplica necessariamente a todos os Estados da nação, mas a maior parte deles, sendo notória a precariedade institucional em que certas áreas do sistema judiciário trabalham.

Cabe ressaltar que, conforme o Provimento n³6 de 24 de abril de 2014 do Conselho Nacional de Justiça, foi estabelecido que em até 90 dias a contar desta data, os tribunais de justiça deveriam providenciar estudos para instalar varas de competência exclusiva em matéria de infância e juventude nas comarcas com mais de 100 mil habitantes. Ora, passados cinco anos do referido provimento, a cidade do Rio de Janeiro que conta aproximadamente com 6 milhões de habitantes, possui apenas 4 varas especializadas ${ }^{84}$, ou seja, é neste cenário que a conta realmente não fecha, sequer nas grandes capitais do país.

Importante ressaltar que, além do descumprimento supracitado, parte dos juízos especializados muitas vezes são obrigados a atuar sem possuir ao menos uma equipe interprofissional (psicólogos e assistentes sociais) e nos locais em que existem esses profissionais qualificados, grande parte fica sobrecarregada com as inúmeras demandas, tendo que se dividir entre os diferentes casos abrangidos pela competência das varas da infância e juventude que, obviamente, não se restringem à adoção e pela sua natureza tendem a possuir um caráter urgente.

Desta forma, desmedida é a responsabilização exclusiva do magistrado para decidir o futuro de uma criança acolhida ou de uma família sem que tenha contado com a assistência de profissionais qualificados, visto que o Direito não se resume a simples aplicação da lei, mas a adequação desta em < http://infanciaejuventude.tjrj.jus.br/informacoes/relacao-varas.html>. Acesso 19 nov 2019. 
diante de cada caso em concreto, que perpassa questões subjetivas questões estas que deveriam ser analisadas por profissionais especializados - num eterno equilíbrio de princípios.

Apesar de todas as legislações em vigor relativas ao tema terem sido idealizadas para atingirem o melhor interesse da criança - característica norteadora da Doutrina da Proteção Integral -, a diferença de entendimento acerca desse princípio ocasiona erros drásticos. O melhor interesse da criança precisa ser observado pelos olhos desses pequenos que acordam diariamente sem um pai ou uma mãe, bem como pela interpretação de especialistas que possuem aptidão técnica em compreender os reais sentimentos desses indivíduos em formação, e não apenas por adultos que tiveram o privilégio de crescer seguros no seio de uma família biológica e, por isso, tentam impor essa realidade às pessoas que infelizmente não a possuem.

Portanto, as crianças precisam ser escutadas e os especialistas precisam ser consultados, não sendo essa uma tarefa restrita aos promotores de justiça, aos defensores públicos, aos advogados, aos magistrados ou aos políticos, mas sim a toda uma sociedade que tem o dever constitucional de cobrar mudanças, visando evitar consequências drásticas e irreversíveis como as que Donald Woods Winnicott, pediatra e psicanalista inglês, traduz de uma maneira bastante forte:

"A criança cujo lar não conseguiu the dar um sentimento de segurança procura as quatro paredes fora de casa; ainda tem esperanças e busca avós, tios e tias, amigos da família, a escola. Procura uma estabilidade externa, sem a qual pode enlouquecer (...) As crianças privadas de uma vida no lar ou devem receber alguma provisão, algo de estável e pessoal, quando ainda não suficientemente jovens para fazer uso disto em certa extensão, ou então são obrigadas a nos forçar a oferecer-lhes estabilidade mais tarde, sob a forma de uma escola autorizada ou, como último recurso, quatro paredes sob a forma de uma cela em um cárcere" ${ }^{" 85}$.

85 FILHO, Luiz Schettini. Op. cit., p. 25. 


\section{BIBLIOGRAFIA}

AOKI, Luiz Paulo Santos. Comentários ao art. 31 do ECA. In: CCURY, Munir (Coord.). Estatuto da Criança e do adolescente comentado comentários jurídicos e sociais. 7 ed.. São Paulo: Malheiros, 2005.

CÁPUA, Valdeci Ataíde. Adoção Internacional: procedimentos legais. $1^{\text {a }}$ ed.(ano 2009), $2^{a}$ reimpr.. Curitiba: Juruá, 2012.

CAVALLIERI, Leila Arruda. $O$ direito internacional e a criança: adoção transnacional e nacionalidade do adotado. Belo Horizonte: Arraes Editora Ltda, 2017.

CHAVES, Antônio. A Legitimação Adotiva, Forma Mais Avançada de Integração de Crianças Abandonadas ou Expostas, em Lares Substitutos. Diferenças, Inconvenientes e Vantagens com Referência à Adoção, p. 5 Disponível em <https://www.revistas.usp.br/rfdusp/article/download/66528/69138>. Acesso em 23 set. 2019.

Código Civil de 1916. Disponível em <http://www.planalto.gov.br/ccivil_03/LEIS/L3071.htm>. Acesso 10 nov 2019.

Código dos Menores, Decreto $\mathrm{n}^{\circ}$ 17.943-a de 12 de outubro de 1927. Disponível em <http://www.planalto.gov.br/ccivil_03/decreto/19101929/D17943A.htm>. Acesso em 10 de nov de 2019.

Convenção Relativa à Proteção das Crianças e à Cooperação em Matéria de Adoção Internacional, concluída na Haia, em 29 de maio de 1993. Decreto no 3.087, de 21 de junho de 1999. Disponível em < http://www.planalto.gov.br/ccivil_03/decreto/d3087.htm>. Acesso 10 nov 2019.

Convenção sobre os Direitos da Criança. Decreto $\mathrm{n}^{\circ} 99.710$, de 21 de novembro de 1990.2 Disponível em <http://www.planalto.gov.br/ccivil_03/decreto/1990-1994/D99710.htm>. Acesso em 10 nov 2019.

Declaração Universal dos Direitos da Criança de 1959. Disponível em $<$ https://www2.camara.leg.br/atividade-legislativa/comissoes/comissoespermanentes/cdhm/comite-brasileiro-de-direitos-humanos-e-politicaexterna/DeclDirCrian.html>. Acesso em 10 nov 2019. 
Declaração Universal dos Direitos Humanos. Disponível em <https://www.ohchr.org/EN/UDHR/Pages/Language.aspx?LangID=por>. Acesso em 10 nov 2019.

Decreto-Lei 229 de 28 de fevereiro de 1967. Disponível em <http://www.planalto.gov.br/ccivil_03/decreto-lei/Del0229.htm>. Acesso em 10 nov 2019.

DIAS, Maria Berenice. Filhos do afeto: questões jurídicas. São Paulo: Revista dos Tribunais, 2016.

DIAS, Maria Berenice. Manual de Direito das Famílias, $11^{\mathrm{a}}$ ed. rev., atual. e ampl., São Paulo: Editora Revista dos Tribunais Ltda, 2016.

DINIZ, Maria Helena. Curso de direito civil brasileiro. Vol 5: direito de família. 21ª Ed. Saraiva: São Paulo, 2006.

Estatuto da Criança e do Adolescente. Lei $\mathrm{n}^{\circ}$ 8.069, de 13 de julho de 1990. Disponível em < http://www.planalto.gov.br/ccivil_03/leis/18069.htm>. Acesso em 10 nov 2019.

FACHIN, Luiz Edson. Elementos críticos do direito de família. 3 ed.. Rio de Janeiro: Renovar, 2012.

FILHO, Luiz Schettini. Pedagogia da adoção: criando e educando filhos adotivos. $3^{\mathrm{a}}$ ed.. Curitiba: Juruá, 2017.

FONSECA, Antonio Cezar Lima da. Direito da Criança e do Adolescente. São Paulo: Atlas S.A., 2011.

FREITAS, Lúcia Maria de Paula. Adoção - Quem de nós quer um filho? Revista Brasileira de Direito de Família. Porto Alegre, n. 10, p. 146-155, jul/set., 2001.

GRANATO, Eunice Ferreira Rodrigues. Adoção - Doutrina e prática. 3. tir. Juruá: Curitiba, 2005.

LARA, Camila Orofino de. A adoção da criança à luz da proteção integral, com ênfase na modalidade póstuma. Rio Grande do Sul, 2012. Trabalho de conclusão de curso para obtenção do grau de Bacharel em Ciências Jurídicas e Sociais pela Pontifícia Universidade Católica do Rio Grande do Sul. Disponível em <http://www.pucrs.br/direito/wpcontent/uploads/sites/11/2018/09/camila_lara.pdf $>$. Acesso em 23 set. 2019. 
Lei $n$ 3.133, de 8 de maio de 1957. Disponível em <http://www.planalto.gov.br/ccivil_03/leis/1950-1969/L3133.htm>. Acesso em 10 nov 2019.

Lei $n^{o} 4.655$, de 2 de junho de 1965, dispõe sobre legitimidade adotiva. Disponível em <http://www.planalto.gov.br/ccivil_03/leis/19501969/L4655.htm>. Acesso em 10 nov 2019.

Lei Portuguesa $n^{\circ} 103$, de 11 de setembro de 2009. Disponível em $<$ http://www.pgdlisboa.pt/leis/lei_mostra_articulado.php?nid=1128\&tabela $=$ leis\&so_miolo=>. Acesso em 9 out. 2019.

MACIEL, Kátia Regina Ferreira Lobo Andrade. Curso de Direito da Criança e do Adolescente: aspectos teóricos e práticos. $8^{\mathrm{a}}$ ed. rev. e atual.. São Paulo: Saraiva, 2015.

MARCÍLIO, Maria Luiza. História social da criança abandonada. São Paulo: Hucitec, 1998.

MATOS, Ana Carla Harmatiuk. O princípio do melhor interesse da criança nos processos de adoção e o direito fundamental à família substituta. Disponível em <http://revistaeletronicardfd.unibrasil.com.br/index.php/rdfd/article/view/33 6/286> . Acesso 10 nov 2019.

NUCCI, Guilherme de Souza. Estatuto da Criança e do Adolescente Comentado: em busca da Constituição Federal das Crianças e dos Adolescentes. $3^{a}$ ed.. Rio de Janeiro: Forense, 2017.

Parecer $n^{\circ} 71$ de 2018 da Comissão de Direitos Humanos e Legislação Participativa do Senado Federal. Disponível em < https://legis.senado.leg.br/sdleggetter/documento?dm=7892759\&ts=1567534682922\&disposition=inline > Acesso 11 nov 2019.

Passo a passo da adoção. Disponível em $<$ https://www.cnj.jus.br/programas-e-acoes/adocao/passo-a-passo-daadocao/>. Acesso 19 nov 2019.

PEREIRA, Caio Mário da Silva. Instituições de Direito Civil (volume V) Direito de Família, 26ª ed.. Rio de Janeiro: Editora Gen e Forense, 2018.

PEREIRA, Rodrigo da Cunha. Direito de Família e Psicanálise. São Paulo: Imago, 2003. 
PEREIRA, Tânia da Silva. $O$ "acolhimento" $e$ o "melhor interesse da criança" como princípios norteadores da proteção da infância e da juventude.

Disponível

em

<http://www.ibdfam.org.br/_img/artigos/Acolhimento\%20Familiar.pdf>.

Acesso 10 nov 2019.

PEREIRA, Tânia da Silva. O princípio do "melhor interesse da criança": da teoria à prática. Disponível em <https://www.gontijofamilia.adv.br/2008/artigos_pdf/Tania_da_Silva_Pereira/MelhorInteresse.p df>. Acesso em 30 out. 2019.

Plano nacional de proteção e defesa do direito de crianças e adolescentes à convivência familiar e comunitária. Disponível em <https://www.mds.gov.br/webarquivos/publicacao/assistencia_social/Cader nos/Plano_Defesa_CriancasAdolescentes\%20.pdf $>$. Acesso em 29 set. 2019.

Política de atenção à gestante: Apoio profissional para uma decisão amadurecida sobre permanecer ou não com a criança, TJSP. Disponível em <http://www.desenvolvimentosocial.sp.gov.br/a2sitebox/arquivos/documen tos/873.pdf >. Acesso em 12 out. 2019.

Projeto "Abrigo de Portas Abertas". Disponível em $<$ http://infanciaejuventude.tjrj.jus.br/boaspraticas/docs/projetoportasabertas.pdf >. Acesso em 15 out 2019.

Projeto "Afeto que afeta" criado pela $1^{\mathrm{a}}$ Vara da Infância, da Juventude e do Idoso da Comarca da Capital do Estado do Rio de Janeiro. Disponível em <http://infanciaejuventude.tjrj.jus.br/boaspraticas/projetos/1varacapital/apafetivo.html $>$. Acesso em 09 out. 2019.

Projeto Apadrinhar criado pela $3^{\text {a }}$ Vara da Infância, da Juventude e do Idoso da Comarca da Capital do Estado do Rio de Janeiro. Disponível em $<$ http://infanciaejuventude.tjrj.jus.br/boaspraticas/docs/projetoapadrinhar.pdf>. Acesso em 9 out 2019.

Projeto de Lei - Estatuto da Adoção de Criança e Adolescente. Disponível em $<$ https://legis.senado.leg.br/sdleggetter/documento?dm $=7235783 \&$ ts $=1567534682260 \&$ disposition $=$ inline $>$. Acesso 11 nov 2019.

Relatório Legislativo, parecer $n^{\circ}$ de 2019 da Comissão de Constituição, Justiça e Cidadania do Senado Federal. Disponível em < https://legis.senado.leg.br/sdleggetter/documento? $\mathrm{dm}=7935613 \& \mathrm{ts}=1567534683081 \&$ disposition=inline $>$. Acesso 11 nov 2019. 
Resolução $n^{\circ} 54$ do CNJ, de 24 de abril de 2008. Disponível em $<$ https://atos.cnj.jus.br/files/resolucao_54_29042008_25032019202713.pdf $>$. Aceso 10 nov 2019

Resolução $n^{o} 93$ do CNJ, de 27 de outubro de 2009. Disponível em <https://atos.cnj.jus.br/files/resolucao_93_27102009_10102012195711.pdf >. Acesso 11 nov 2019.

Resolução $n^{o} 190$ do CNJ, de 01 de abril de 2014. Disponível em <https://atos.cnj.jus.br/files/resolucao_190_01042014_03042014151312.pd f>. Acesso 11 nov 2019.

Resolução $n^{\circ} 289$ do CNJ, de 14 de agosto de 2019. Disponível em https://atos.cnj.jus.br/files/resolucao_289_14082019_15082019141539.pdf Acesso 10 nov 2019.

Revista $\mathrm{n}^{\circ}$ 31, Crianças Invisíveis do IBDFAM. Disponível em <http://www.ibdfam.org.br/publicacoes/leitor/31.>. Acesso em 14 nov 2019.

STJ, REsp $n^{\circ} 457.635$ PB 2002/0104623-0, Rel. Ministro Ruy Rosado de Aguiar, Quarta Turma, Brasília, 19 nov 2002.

STJ, REsp $n^{\circ} 889.852$ RS 2006/0209137-4, Rel. Ministro Luis Felipe Salomão, Quarta Turma, Brasília, 27 abril 2010.

STJ, REsp $n^{\circ}$ 1.199.465 DF 2010/0120902-0, Rel. Ministra Nancy Andrighi, Terceira Turma, Brasília, 14 jun. 2011.

STJ, REsp $n^{\circ}$ 1.217.415 RS 2010/0184476-0, Rel. Ministra Nancy Andrighi, Terceira Turma, Brasília, 19 jun 2012

STJ, REsp $n^{\circ}$ 1.448.969 SC 2014/0086446-1, Rel. Ministro Moura Ribeiro, Terceira Turma, Brasília, 21 out 2014.

STJ, REsp $n^{\circ}$ 1.785.754 - RS (2018/0322826-2), Rel. Ministro Ricardo Villas Bôas Cueva, Terceira Turma, Brasília, 08 out 2019.

TAVARES, José Farias. Comentários ao Estatuto da Criança e do Adolescente. 8 ed.. Rio de Janeiro: Forense, 2013.

TIBURCIO, Carmen; BARROSO, Luis Roberto. $O$ direito internacional contemporâneo. 4 ed.. Rio de Janeiro: Renovar, 2000. 
TJRS, Apelação Cível $n^{o}$ 70067076836, Sétima Câmara Cível, Desembargadora Rel. Liselena Schifino Robles Ribeiro, Porto Alegre, 02 dez 2015. 